Universidade de Brasília

Centro de Excelência em Turismo

Curso para Professores e Pesquisadores em Turismo e Hospitalidade

\title{
Dano Moral na Hospitalidade
}

Márcia Aparecida Marcondes de Moura

Professora e Doutora Tânia Siqueira Montoro

Monografia apresentada ao Centro de Excelência em Turismo da Universidade de Brasília como requisito parcial para a obtenção do certificado de Curso para Professores e Pesquisadores em Turismo e Hospitalidade.

Brasília, DF, Dezembro de 2003. 
UNIVERSIDADE DE BRASÍLIA

Centro de Excelência em Turismo

Curso para Professores e Pesquisadores em Turismo e Hospitalidade

\section{Dano Moral na Hospitalidade}

Márcia Aparecida Marcondes de Moura

Banca Examinadora

Tânia Siqueira Montoro: Doutora em Comunicação Audiovisual e Publicidade pela Universidade Autônoma de Barcelona

Orientadora

Nome, titulação

Membro da Banca

Brasília, DF, 03 de Dezembro de 2003. 
MARCIA APARECIDA MARCONDES DE MOURA

\title{
Dano Moral na Hospitalidade
}

\author{
Comissão Avaliadora
}
Professora e Doutora Tânia Siqueira Montoro
Professora Orientadora

\section{Prof. X}

Prof. Y

Brasília, DF, 03 de Dezembro de 2003. 
Moura, Márcia Aparecida Marcondes.

Dano Moral na Hospitalidade / Moura, Márcia Aparecida Marcondes de Moura - Brasília: UnB / CET, 2003.

124 pág.

Monografia (Especialização) - Universidade de Brasília. Centro de Excelência em Turismo, 2003.

1. Meios de Hospedagem - Responsabilidade. 2. Código de Defesa do Consumidor aplicado ao Turismo e Hospitalidade. 3. Danos Morais. 4. Turismo - Monografia ISBN 
À minha filha Dayse, incansável incentivadora.

À minhas amigas Beth e Cássia, companheiras de todas as horas, por todo o apoio ao longo dessa caminhada.

À professora e orientadora Tânia Montoro, sempre preocupada com os rumos desse aprendizado. 
LISTA DE ABREVIATURAS E SIGLAS

$\begin{array}{lll}\text { Abav } & - & \text { Associação Brasileira das Agências de Viagens } \\ \text { Abih } & - & \text { Associação Brasileira } \\ \text { Ac. } & - & \text { Acordão } \\ \text { Art. } & - & \text { Artigo } \\ \text { Ap. } & - & \text { Apelação } \\ \text { ApCiv. } & - & \text { Apelação Civil } \\ \text { Câm. } & - & \text { Câmara } \\ \text { CC } & - & \text { Código Civil } \\ \text { CDC } & - & \text { Código de Defesa do Consumidor } \\ \text { CPC } & - & \text { Código de Processo Civil } \\ \text { CNDC } & - & \text { Conselho Nacional de Defesa do Consumidor } \\ \text { CF } & - & \text { Constituição Federal } \\ \text { DECON } & - & \text { Delegacia do Consumidor } \\ \text { Ed. } & - & \text { Edição } \\ \text { JEC } & - & \text { Juizado Especial Civil } \\ \text { Pág. } & - & \text { Página } \\ \text { PROCON } & - & \text { Programa de Orientação do Consumidor } \\ \text { RC } & - & \text { Revista do Consumidor } \\ \text { Rel. } & - & \text { Relator } \\ \text { RF } & - & \text { Revista Forense } \\ \text { RT } & - & \text { Revista dos Tribunais } \\ \text { STJ } & - & \text { Superior Tribunal de Justiça } \\ \text { STF } & - & \text { Supremo Tribunal Federal } \\ \text { TA } & - & \text { Tribunal de Alçada } \\ \text { TAMG } & - & \text { Tribunal de Alçada de Minas Gerias } \\ \text { TASP } & - & \text { Tribunal de Alçada de São Paulo } \\ \text { TARJ } & - & \text { Tribunal de Alçada do Rio de Janeiro } \\ \text { TJ } & - & \text { Tribunal de Justiça } \\ \text { TJMG } & - & \text { Tribunal de Justiça de Minas Gerais } \\ \text { TJRS } & - & \text { Tribunal de Justiça do Rio Grande do Sul } \\ \text { TJSP } & - & \text { Tribunal de Justiça de São Paulo } \\ \text { TFR } & - & \text { Tribunal Federal de Recursos } \\ \text { UH } & - & \text { Unidade Habitacionall } \\ & & \end{array}$




\section{SUMÁRIO}

\section{Lista de Abreviaturas}

I - DO DANO MORAL

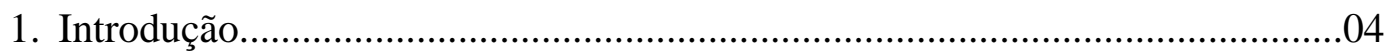

2. Definições iniciais sobre a atividade do turismo................................................06

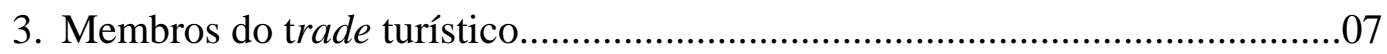

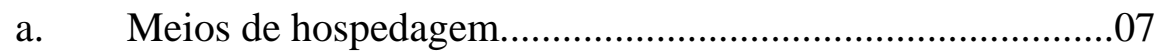

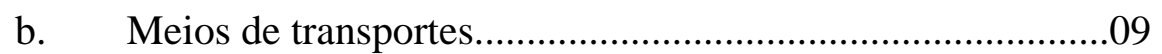

c. Agências de viagem e turismo.............................................10

d. Agências de viagens...........................................................10

e. Organizadores de eventos...................................................10

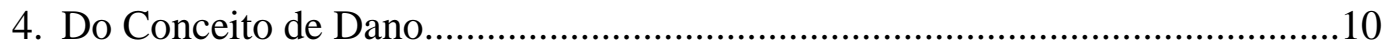

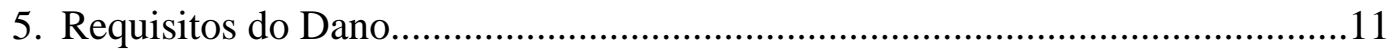

6. Dano Moral - Conceituações..........................................................................11

7. A relação entre o Dano Patrimonial e Dano Moral...........................................12

8. Elementos que fundamentam o Dano Moral.....................................................12

9. A Constituição Federal vigente e o Dano Moral...............................................13

10. O Código Civil e o Dano Moral...........................................................14

11. O Código de Defesa do Consumidor e o Dano Moral.............................15

12. A Pessoa Jurídica e o Dano Moral..........................................................17

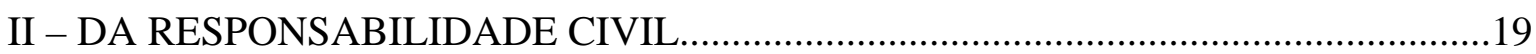

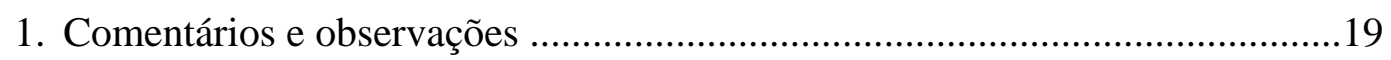

2. Elementos e Espécies de responsabilidade ...................................................20

3. Função da Responsabilidade Civil...............................................................21

4. A Responsabilidade Civil e o Dano Moral........................................................21

5. A Responsabilidade Civil nas Relações de Consumo.......................................23

6. A Responsabilidade Civil dos Hoteleiros e proprietários de meios de

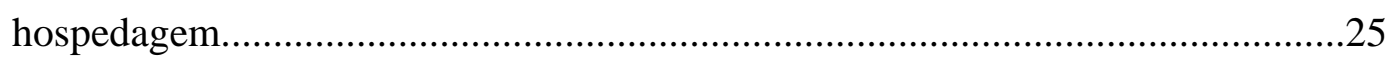


III - A APLICAÇÃO DO CÓDIGO DE DEFESA DO CONSUMIDOR NO TURISMO (COM ÊNFASE NO CONSUMIDOR DOS MEIOS DE

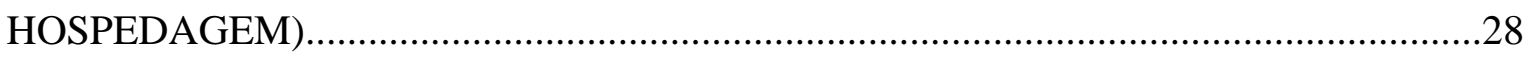

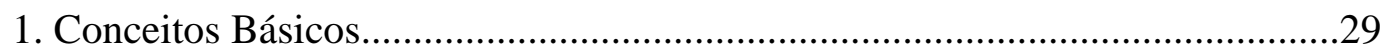

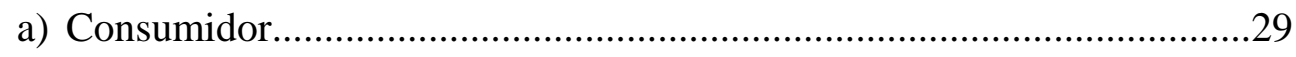

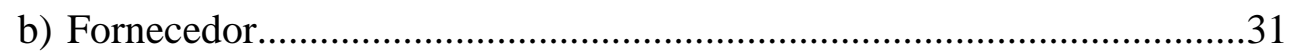

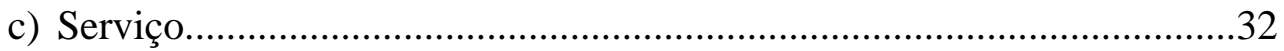

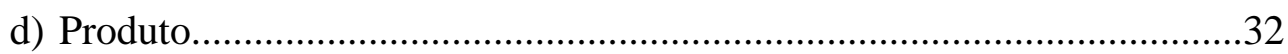

e) Relação de Consumo...................................................................................32

2. Princípios............................................................................................................33

a) Princípio da vulnerabilidade ……………………….......33

b) Princípio da boa-fé..........................................................35

c) Princípio da confiança......................................................35

d) Princípio da transparência...............................................37

e) Princípio da hipossuficiência...........................................37

f) Princípio do acesso à justiça.............................................38

IV - DO CONTRATO DE TURISMO E HOSPITALIDADE...............................................39

1. Contrato de Viagem..........................................................................................

2. Contrato de Turismo...........................................................................................

a) Agencias de turismo...............................................................4

b) Empresa hoteleira.................................................................42

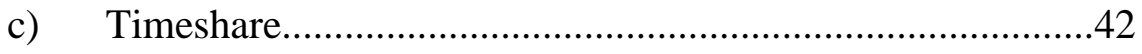

d) Empresas de Transportes..........................................................43

3. Contrato de Hospedagem..................................................................................44

a) Hospedagem remunerada.......................................................4

b) Hospedagem profissional......................................................4

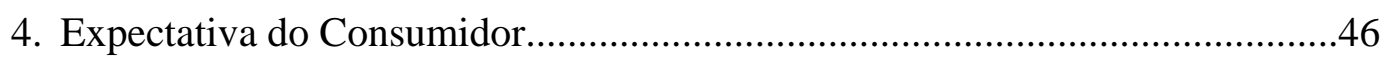

5. A oferta no Contrato de Turismo e Hospitalidade................................................47

6. A publicidade no Turismo e Hospitalidade............................................................50 
V - DA RESPONSÁBILIDADE NO CONTRATO DE TURISMO E HOSPITALIDADE EM FACE DO CÓDIGO DE DEFESA DO

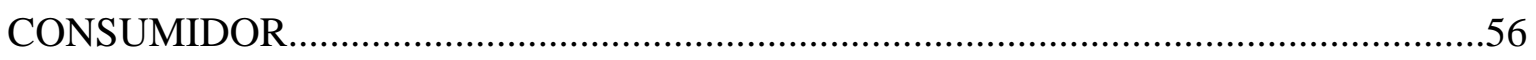

1. Responsabilidade objetiva no Código de Defesa do

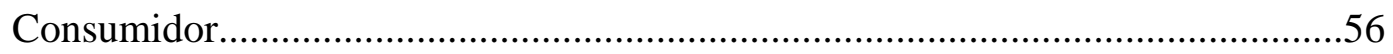

2. Responsabilidade pelo fato do serviço.........................................................57

3. Responsabilidade por vício do serviço.........................................................59

4. Responsabilidade em face do descumprimento da oferta...............................60

5. Responsabilidade solidária dos fornecedores em anúncios publicitários

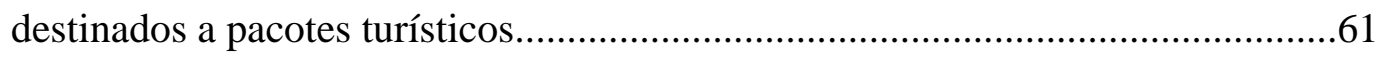

6. Responsabilidade por Danos Morais................................................................63

VI - A REPARAÇÃO DO DANO MORAL - COMENTÁRIOS FACE A APLICAÇÃO NOS MEIOS DE HOSPEDAGEM..........................................................................66

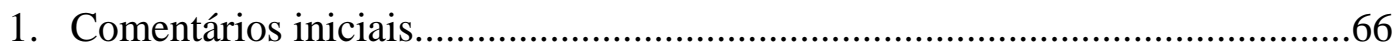

2. Reparação do Dano Moral ........................................................................68

3. A prova no Dano Moral.......................................................................... 70

4. Legitimidade para pleitear a indenização..................................................... 72

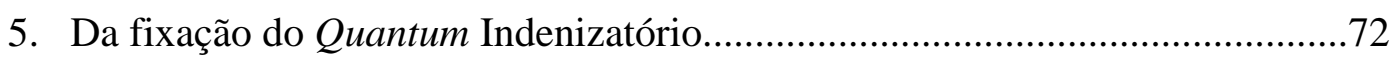

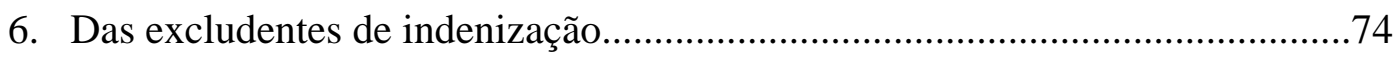

a) por culpa exclusiva da vítima..........................................75

b) por caso fortuito ou força maior.......................................75

c) por culpa concorrente da vítima e do agente......................75

d) por culpa de terceiro......................................................75

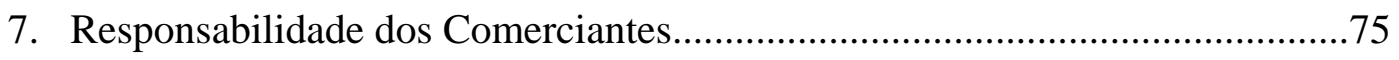

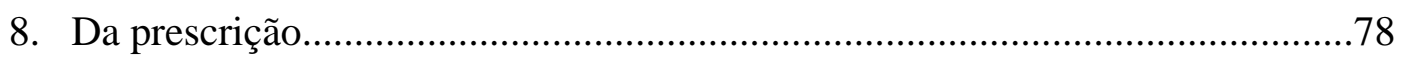


1. Soluções extrajudiciais apenas para danos materiais......................................81

Programa de Orientação ao Consumidor - PROCON.............................81

2. Soluções judiciais para danos materiais e morais ..........................................82

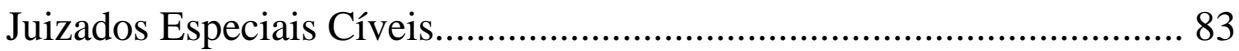

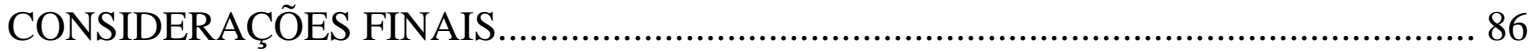

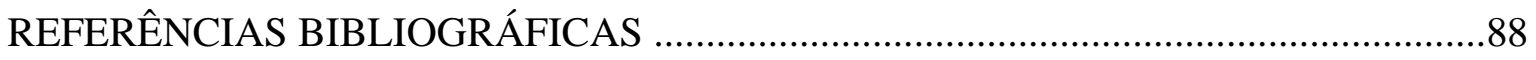

ANEXOS

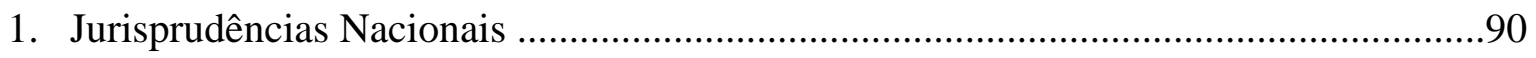

2. Casos Reais - Depoimentos - Comentários .........................................................98

3. Cópias de Artigos publicados em anexo............................................................... 123 


\section{APRESENTAÇÃO}

Em matéria de Turismo, todos os temas são envolventes, mas nada consegue equiparar-se à relação jurídica que envolve o Consumo e o Turismo / Hospitalidade nos dias atuais.

O assunto, além de muito interessante, é protegido duplamente pela Constituição Federal, uma vez que a relação turismo/hóspede/consumidor abrange não só os direitos fundamentais, como também os direitos sociais.

O Contrato de Turismo/Hospitalidade e suas conseqüências nunca tiveram abordagem jurídica completa em face do Código de Defesa do Consumidor, ou mesmo do Código Civil, e, economicamente, vêm tendo alto crescimento em nossa economia globalizada.

Daí a importância de dar-se uma maior atenção às questões e relações envolvendo o turismo e hospitalidade e aos cuidados que devem ser tomados a fim de prevenir responsabilidades e coibir abusos, já que não só são devidos ressarcimentos por danos materiais, mas também pelos danos morais provocados pela prestação de serviço de turismo ou hospitalidade defeituosa, imprópria, precária e em desconformidade com o que foi vendido aos consumidores.

O fato é facilmente comprovado. O crescente número de ações judiciais, cujo objeto é o ressarcimento de danos materiais cumulado com pedido de indenização por danos morais e em que figura num dos pólos da ação, um prestador de serviços turísticos (hotéis, pousadas, agências de viagens, operadoras, empresas que prestam serviços a turistas, etc), tem chamado a atenção, haja vista buscar-se atualmente na justiça não só o ressarcimento de um prejuízo material, facilmente comprovável, mas, sobretudo, um ressarcimento/indenização pelo dano moral provocado, tanto pelo abalo emocional (perturbação, intranqüilidade, angústia, preocupação, humilhação, frustração, etc.), como também pelo serviço não corresponder às expectativas desejadas. Tal fato tem surpreendido face à dificuldade de mensuração de sentimentos e expectativas pelo julgador e algumas distorções do conceito jurídico de dano moral . 
Constitui uma conquista relativamente recente no campo do direito a convicção da necessidade de reparação de dano moral no turismo/hospitalidade. Faltam pesquisas e orientações na área, a doutrina e legislação existentes sobre a matéria são escassas e insuficientes e, muitas vezes, não acompanham as transformações ocorrentes tanto no Brasil como no exterior. Não que se queira desconsiderar o Código de Defesa do Consumidor, que em muito contribuiu para o estabelecimento de regras entre o turista, na condição de consumidor final, e a empresa turística, na qualidade de fornecedora de serviço, mas, se o referido código cobre uma série de situações, não cobre sua totalidade. E com isso o turista/hóspede, hoje, acaba ficando desprotegido em vários aspectos.

Logo, são necessários estudos sobre o tema, pois estamos diante de um segmento que envolve diversos fornecedores para a realização de um serviço para o consumidor, que pretende com esse serviço ter seus sonhos e fantasias realizadas, conseqüentemente aumentando sua vulnerabilidade. Ocorre que esses sonhos por muitas vezes tornam-se verdadeiros pesadelos, porque no turismo e hospitalidade a hipossuficiência e a vulnerabilidade do consumidor estão implícitas, ferindo assim a expectativa de consumo e provocando danos morais que deverão ser ressarcidos como forma de reparar, punir e prevenir.

A monografia foi dividida em sete (VII) títulos (com subtítulos), com o objetivo de oferecer uma visão geral do tema e esclarecimentos oportunos que possibilitem discutir a tese proposta de existência da responsabilidade e reparalidade do dano moral no turismo e, principalmente, na hospitalidade.

O Título I promove as conceituações pertinentes ao tema, principalmente de Dano e Dano Moral, estabelecendo as diferenças, elementos, características e relações com as legislações e Códigos vigentes.

Todo o trabalho de pesquisa que pretendemos apresentar tem por escopo não ser um amontoado de regras legislativas para as partes envolvidas na relação de consumo que resultou em danos morais para uma das partes, mas sim uma proposta de alteração conceitual e cultural na mentalidade da massa consumidora e dos grandes fornecedores de serviços existentes em nosso país. 
A responsabilidade Civil, principalmente na esfera consumerista, deve desempenhar tanto a tarefa de ressarcir os danos sofridos por algum lesado, quanto a de restabelecer o status quo ante, sendo, acima de tudo, um desestímulo a futuras violações (Titulo II)

O Título III visa analisar os principais preceitos do Código de Defesa do Consumidor e suas responsabilidades na relação de consumo que envolve o turismo e hospitalidade no âmbito nacional (mediante jurisprudências e fatos concretos). Neste contexto, sobrelevou a reformulação da relação entre hóspedes - turistas / agências de viagens - meios de hospedagem. Aqueles foram inseridos no conceito de consumidor (CDC, artigo $2^{\circ}$ ), enquanto as agências de viagens e os meios de hospedagem passaram a ser considerados “fornecedores de serviços" (artigo $3^{\circ}$.) Atento a esses fatos, o CDC surgiu para viabilizar que os problemas antes insolúveis, passem a ser tratados com o devido cuidado e com um maior grau de prevenção.

Os Títulos IV e V dispõem sobre os Contratos de Turismo e Hospitalidade e assinalam a responsabilidade, principalmente por danos morais, nos referido contratos em face do Código de Defesa do Consumidor.

O Título VI trata da reparação do dano moral: a prova, a legitimidade para pleitear a indenização a fixação do quantum indenizatório. Apresenta as causas de exclusão de responsabilidades previstas em lei, apesar da responsabilidade objetiva e do entendimento da doutrina a respeito do tema.

O Título VII esclarece e identifica os órgãos competentes aos quais o consumidor turista deve recorrer quando sentir-se lesado em relação a eventuais e inadequados serviços turísticos prestados pelas agências de viagens e meios de hospedagem.

Esta pesquisa, além de servir de instrumento para informação, também mobiliza elementos motivadores de novas investidas na interdisciplinaridade do turismo e do direito. 


\section{I - DO DANO MORAL}

\section{INTRODUÇÃO}

As relações jurídicas encontram-se em constante mutação e adquirem cada vez mais complexidade, devendo os julgadores, enquanto aplicadores do direito e criadores de jurisprudência, prestadores de serviços turísticos e da hospitalidade e clientes/ consumidores estarem atentos à nova realidade.

O turismo tem desempenhado papel fundamental na sociedade, mas todo desenvolvimento social é gerado por inovações, e toda inovação deve gerar regras de conduta que propiciem e assegurem às partes envolvidas um acertamento de suas relações e a satisfação de ambos, sem desmandos ou abusos de um contra outro. É uma atividade muito complexa não só pelo número de agentes envolvidos, mas também pelos diversos aspectos envolvendo o tema.

Atendendo a essa nova realidade, qual seja, ao surgimento de um grande número de ações envolvendo prestadores de serviços turísticos e da hospitalidade, surge a indenização por dano moral, como objeto principal da ação, acompanhada ou não do pedido de ressarcimento de danos materiais.

O dano moral e sua reparação remontam aos tempos antigos. Desde o início das civilizações prevalecia a idéia de que nenhum ato lesivo à pessoa deveria ficar imune, responsabilizando o lesionado a reparar o dano à vítima ou a seus sucessores. Num primeiro momento só se reparava o dano moral se estivesse acompanhado da reparação material, atualmente o dano moral foi desvinculado do material, assim, pode haver somente a indenização por dano moral nas relações consumidor/prestador de serviços.

Casuística comum quanto ao pedido de indenização por danos morais, situa-se no campo do turismo, no qual a publicidade é fator primordial na atração do consumidor. As empresas do ramo anunciam em periódicos e revistas especializadas seus produtos, prometendo sempre o melhor em termos de serviços na viagem pretendida. As 
acomodações dos hotéis de destino dos turistas são geralmente elogiadas pela publicidade, contratam-se passeios a locais turísticos e até restaurantes são recomendados.

Não é incomum que, ao chegarem às cidades de destino, se vejam os turistas em hotéis bem inferiores aos anunciados, os passeios muitas vezes são desorganizados e a maioria das promessas é desonrada pelos fatos da viagem.

O dano moral aí é evidente e decorre, mais uma vez, da desproporção entre o serviço ofertado e o efetivamente colocado à disposição dos turistas. A expectativa em uma viagem de férias é o descanso, a alegria reparadora, o esquecimento do stress. Se o viajante se depara com o aborrecimento, o desconforto e com o stress daí resultante, as razões que o levaram a contratar a viagem deixam de existir, e o que é pior, o tempo perdido de férias não poderá ser reposto jamais. Somente uma compensação financeira poderá, ainda que tangencialmente, devolver-lhe o humor.

No Brasil, os prestadores de serviços em turismo e hospitalidade buscam, de todas as formas e a todo o momento, meios para aumentarem seus lucros na exploração de seus serviços. Todavia negam admitir a necessidade de direcionar uma determinada porcentagem desse faturamento para atender ou ressarcir danos e reclamações relativas à inadequação de serviços fornecidos a seus clientes /consumidores.

Diante dessa conduta, o cliente/consumidor lesado depara-se com dificuldades de reparo de sua frustração em relação aos serviços fornecidos por tais prestadores de serviços, mas há de consignar-se que o quadro tem mudado e os clientes/consumidores estão cada vez buscando obter legalmente seus direitos lesados.

Não se pode deixar de consignar que a caracterização do dano moral (extrapatrimonial) é extremamente delicada, pois advém da natureza do direito subjetivo danificado, incidindo no plano valorativo da pessoa na sociedade, o que faz alcançar os aspectos mais íntimos da personalidade humana, ou na própria valoração da pessoa no meio em que ela vive e atua. Ele gera no cidadão a necessidade de invocar a tutela jurisdicional, movido pela ilicitude da ação do autor da lesão ou pelo risco que representou. 
Assim, o assunto interessa tanto aos prestadores de serviços turísticos quanto aos clientes/consumidores, pois o que se busca é demonstrar que a relação entre prestadores de serviços em hotelaria e turismo e clientes consumidores deverá ser respaldada pela perfeita "harmonia” de direitos e deveres, ou seja, as partes devem praticar seus atos amparados pela boa-fé, que deverá ser uma “regra de conduta”, pela transparência na oferta e publicidade, pela confiança nas informações fornecidas e pelo reconhecimento da hipossuficiência do consumidor em relação aos serviços contratados, caso contrário, poderá responder por danos materiais ou morais.

\section{DEFINIÇÕES INICIAIS SOBRE A ATIVIDADE DO TURISMO}

Trade turístico é o conjunto de empresas prestadoras de serviços criadas para, de alguma forma, atender às necessidades comuns dos turistas.

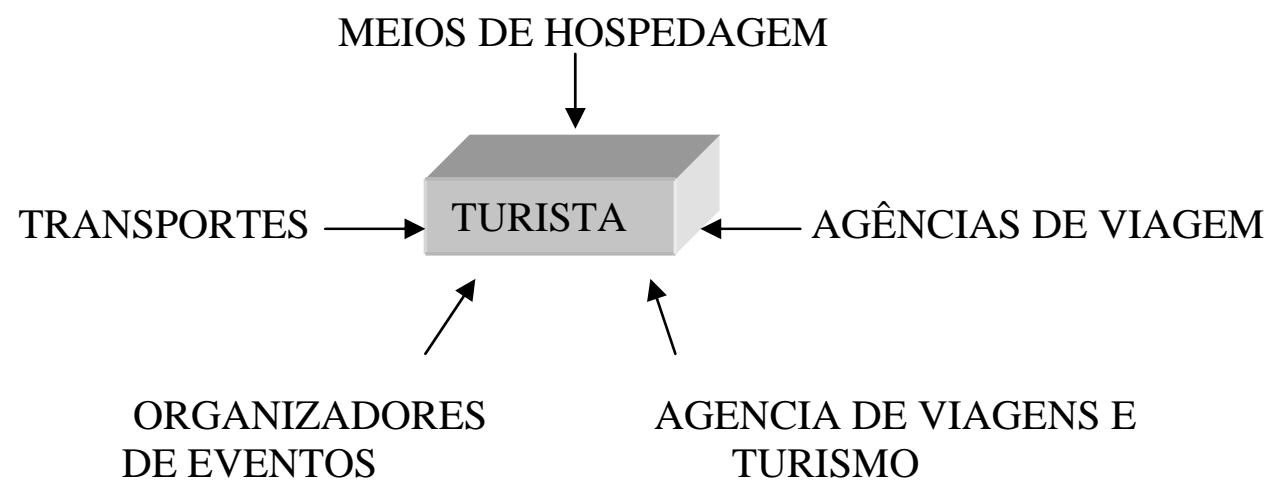

Turismo: Turismo vem do francês tourisme e do inglês tourism e significa o gosto pelas viagens ou por excursões recreativas. No dicionário, turismo é conceituado como a "ação ou efeito de viajar, basicamente com fins de entretenimento e eventualmente outras atividades (culturais, negócios etc.)”. Em termos gerais, pode-se dizer que o turismo é a viagem ou excursão feita por prazer a locais que despertam interesse. A jurisprudência não distingue a viagem feita por prazer da viagem feita pelo executivo em razão de negócios, a serviço da empresa. É perfeitamente possível a concomitância da viagem profissional (turismo de negócios) com o turismo de lazer.

Turista: toda pessoa que efetua uma viagem a logradouro aprazível ou que disponha de atrações culturais, científicas ou de interesse específico, ou ainda, atrações especiais de lazer e diversão, relativamente afastado 
de seu domicilio e fora de sua cidade ou região, nela permanecendo por mais de vinte e quatro horas e menos de três meses. ${ }^{1}$

\section{MEMBROS DO TRADE TURÍSTICO}

\section{a) Meios de hospedagem}

Estabelecimentos comerciais que oferecem o produto (UH - espaço, atingível a partir das áreas principais de circulação comum do estabelecimento, destinado à utilização pelo hóspede, para o seu bem-estar, higiene e repouso): quarto, apartamento, suíte, etc. e satisfaz, cumulativamente, as seguintes condições:

- licenciado pelas autoridades competentes para prestar serviço de hospedagem;

- administrado ou explorado comercialmente por empresa hoteleira e que adota, no relacionamento com os hóspedes, contrato de hospedagem, com as características definidas pelo Regulamento dos Meios de Hospedagem da Embratur e pelas demais legislações aplicáveis;

- atender aos padrões classificatórios previstos pela legislação em vigor;

- manter permanente os padrões de classificação”

Deverão oferecer ao hóspede no mínimo:

- alojamento, para uso temporário do hóspede, em Unidades Habitacionais (UH) específicas a essa finalidade;

- serviços mínimos necessários ao hóspede, consistentes em, recepção, portaria para atendimento e controle permanentes de entrada e saída;

- guarda de bagagem e objetos de uso pessoal dos hóspedes em local apropriado;

- conservação, arrumação e limpeza das instalações e equipamentos.

Tipos de classificação e categoria dos meios de hospedagem

- própria

- Abih (asteriscos) - superior, luxo, econômico e turístico

\footnotetext{
${ }^{1}$ CAMPOS, Luiz Cláudio de A. Menescal, GONÇALVES, Maria Helena Barreto. Introdução ao turismo e hotelaria. Rio de Janeiro: Senac Nacional, 1998, pág.10).
} 
- Embratur (estrelas):

1) Hotel $(\mathrm{H})-01$ a 05 estrelas

2) Hotel de lazer (HL) - 01 a 05 estrelas

3) Hotel histórico (HH) - 01 a 05 estrelas

4) Pousada (P) - 01 a 05 estrelas

5) Lodge - tipo ambiental ou ecológico

- classificação standard ou especial

Itens para classificação por estrelas:

- Aspectos construtivos (UHs, lazer e serviços)

- Equipamentos e instalações (UHs, lazer e serviços)

- Serviços obrigatórios e complementares

\begin{tabular}{|l|l|lllll|}
\hline CATEGORIA & SIMBOLO & \multicolumn{4}{|l|}{ TIPO DE } & HOTEL \\
\hline Luxo superior & $* * * * *$ & H & HL & HH & P \\
\hline Luxo & $* * * *$ & H & HL & HH & P \\
\hline Standard superior & $* * *$ & H & HL & HH & P \\
\hline Standard & $* *$ & H & HL & HH & P & \\
\hline Simples & $*$ & H & HL & HH & P \\
\hline
\end{tabular}

Meios de hospedagem hoteleiros:

- Hotel: Comércio que, mediante o pagamento de diária, oferece quarto com banheiro privativo, para ocupação temporária, podendo oferecer outros serviços extras. O hotel tem subdivisões relativas ao seu público alvo e/ou a edificação.

- Hotel de Lazer: É o estabelecimento que possui equipamentos de lazer e repouso adequados a sua característica localização. Na nova classificação da EMBRATUR, só poderão ter essa classificação os estabelecimentos que estejam fora de zonas urbanas.

- Hotel Executivo: Está sempre localizado em zona urbana e tem seu marketing voltado para atender turistas gerados pelas empresas (viagem a negócios, treinamentos, reuniões, etc.) 
- Hotel Histórico: Estabelecimento instalado em edificação reconhecida pelo poder público como de interesse cultural e/ou histórico.

- Pousada: Edificação de valor histórico em localidade turística, caracterizada por ter hospitalidade e ambiente simples e aconchegante, integrada à região.

- Lodge ou hotel de selva: Hotel localizado em ambiente de natureza quase intocada e que se integra totalmente ao mesmo, sem destoar das características da região.

- Flat: Condomínio com serviços de hotel, onde pessoas se unem e locam seus apartamentos pelo sistema de "POOL”(sem a Lei do Inquilinato).

- Motel e/ou hotel de alta rotatividade: idem ao hotel, entretanto deve-se trocar a palavra “diária” por “período de horas”.

\section{Principais meios de hospedagem extra-hoteleiros:}

- Hostal: Utilização parcial de antigos edifícios com alguns serviços de hotelaria.

- Albergue da juventude: Local que visa estimular o turismo de baixo custo e o intercâmbio cultural entre os sócios.

- Camping: Área cercada que possui o mínimo de serviços de higiene necessários ao dia-a-dia .

- Paradores: Antigos palácios ou casas reais que mantêm intactas suas características interiores e exteriores.

- Colônia de férias: Normalmente pertencente a associações ou empresas, oferece períodos previamente estabelecidos com custo muito reduzido e serviços idem, pois não visa a lucros.

b) Meios de transporte 
Englobam os transportes ferroviário, rodoviário e aéreo, locadoras de veículos e, em alguns casos, até o próprio turista, traduzindo-se numa atividade comercial.

\section{c) Agências de viagens e turismo}

Também chamadas operadoras, organizam, promovem e vendem os "pacotes turísticos”. Essas agências atuam junto aos transportadores (venda de bilhetes, passagens, locações de veículos, etc.) e aos meios de hospedagem (emissão de vouchers, reservas de aptos., etc.)

\section{d) Agências de viagens}

Respondem pela revenda, mediante comissão, dos “pacotes turísticos” elaborados pelas operadoras.

\section{e) Organizadores de eventos}

Empresas ou departamento dentro delas, que se responsabilizam pela operacionalização de eventos como reuniões, treinamentos, convenções, confraternizações, etc.

\section{DO CONCEITO DE DANO}

No início da abordagem do tema a seguir enfrentado, impõe-se delimitar com precisão o que seja dano, dano moral puro e dano material.

Para tanto, socorremo-nos da melhor doutrina.

Dano, do latim “damnum”, genericamente significa ofensa, mal.

É todo prejuízo causado a outrem por culpa ou dolo. 
O dano é resultado de uma lesão que poderá situar-se no âmbito material ou no âmbito moral. "É um desequilíbrio sofrido pelo sujeito de direito, pessoa física ou jurídica, atingida no patrimônio ou na moral, em conseqüência da violação da norma jurídica por fato ou ato alheio.” 2

Assim, como não há responsabilidade civil sem dano, também não há dano sem vítima ou lesado.

\section{REQUISITOS DO DANO}

Uma vez que o dano lesiona bens patrimoniais, pessoais ou morais, sobre os quais o lesado tinha um interesse, para que haja dano indenizável é necessária a ocorrência dos seguintes requisitos: a) um interesse sobre um bem que haja sofrido diminuição ou destruição, pertencente a uma pessoa; b) a certeza do dano, ou seja, a sua efetividade; c) o dano deve subsistir ao tempo do ressarcimento; d) que a lesão ou sofrimento deve afetar um interesse próprio.

\section{DO DANO MORAL - CONCEITUAÇÕES}

O dano moral é aquele suportado pela pessoa quando à mesma é imposta a dor, a vergonha, a humilhação, o aborrecimento, o abalo de sua honra, agressão a princípios pessoais, ou seja, tudo aquilo que estaria extra ao dano material e que não tem valor certo e determinado.

Assim, o dano moral é aquele que afeta a paz interior de uma pessoa, atingindo-lhe o sentimento, o decoro, o ego, a honra, enfim, tudo o que não tem valor econômico, mas o que lhe causa dor e sofrimento. É, pois, a dor física e/ou psicológica sentida pelo indivíduo. ${ }^{3}$

\footnotetext{
2 JUNIOR, Cretella. Tratado. Rio de Janeiro: Forense, 1970. Vol.VIII, pág. 108) .

3 NUNES, Luiz Antônio Rizzato; CALDEIRA, Mirella D’Angelo. O Dano Moral e sua Interpretação Jurisdicional. São Paulo: Saraiva, 1999, pág.1.
} 
Parece mais razoável assim, caracterizar o dano moral pelos seus próprios elementos: "como a privação ou diminuição daqueles bens que têm um valor precípuo na vida do homem e que são a paz, a tranqüilidade de espírito, a liberdade individual, a integridade individual, a integridade física, a honra e os demais sagrados afetos"; classificando-se, desse modo, em dano que afeta a "parte social do patrimônio moral" (honra, reputação, etc.) e dano que molesta a "parte do patrimônio moral" (dor, tristeza, saudade, etc.); dano moral que provoca direta ou indiretamente dano patrimonial (cicatriz deformante, etc.) e dano moral puro (dor, tristeza, etc.). ${ }^{4}$

\section{A RELAÇÃO ENTRE DANO PATRIMONIAL E DANO MORAL}

Sob o critério do objeto, o dano moral classifica-se em dano patrimonial e dano extrapatrimonial ou moral.

O dano patrimonial está vinculado ao conceito de patrimônio (conjunto de bens de uma pessoa). Refere-se “a perda ou ao prejuízo praticado diretamente a um bem patrimonial e que diminui o valor dele, anulando ou não a utilidade." 5

Qualquer lesão ao patrimônio da vítima deve ser sempre reparada integralmente e, sempre que possível, através da restituição ao statu quo ante. Quando isso não for possível, o dano patrimonial é avaliado em dinheiro, e a indenização é feita através de indenização pecuniária.

Já o dano moral é considerado como a dor, a angústia, a aflição física ou espiritual, a humilhação, o vexame, o constrangimento, a elevada vergonha, o desconforto, o aborrecimento, a injúria moral, enfim, os padecimentos que são infligidos à vítima do evento danoso. É caracterizado pela ofensa ao íntimo da pessoa.

Há de se observar que nem toda violação a direito da personalidade produz dano moral, ou somente dano dessa natureza; pode ou não haver dano moral, ou este mesclar-se a dano patrimonial, diante de uma multiplicidade de fatores que, em concreto, podem interferir, como: as condições da pessoa; suas reações, seu estado de espírito, a gravidade do fato violador, a intenção do agente, etc. Basta atentar - se para a diversidade de

\footnotetext{
${ }^{4}$ CAHALI, Yussef Said. Dano Moral. 2 ed. São Paulo:Revista dos Tribunais, 2000, pág. 20 5 Compêndio de Responsabilidade Civil, Edição Universitária de Direito, 1992, pág. 273.
} 
conseqüências que um evento danoso pode trazer para a pessoa notória ou comum do povo

\section{8 - ELEMENTOS QUE FUNDAMENTAM O DANO MORAL}

Para caracterizar o dano moral, faz-se necessária a presença de alguns elementos, vejamos: a) o lesante é o agente ativo na realização do ato, é quem dá origem ao pleito de reparação de dano moral. É quem viola o direito do agente passivo da relação, o lesado, que sofrerá as conseqüências do ato ilícito; b) a lesão, que representa o objeto causador do dano sofrido pela vítima e que deverá ser comprovada; c) o ato ilícito é a ação, que ao ser praticada afronta a Lei e o ordenamento jurídico.

\section{A CONSTITUIÇÃO FEDERAL VIGENTE E O DANO MORAL}

A Constituição Federal de 1988 ampliou e elevou de status jurídico o instituto do dano moral, assim, cortou qualquer dúvida que pudesse remanescer a respeito da reparalidade do dano moral.

O dano moral deve ser reparado, e seu fundamento está no fato de que o indivíduo é titular de direitos de personalidade que não podem ser impunemente atingidos. A Constituição Federal de 1988 não deixa mais dúvida aos que resistiam à reparação do dano moral, pois os direitos constitucionais não podem ser interpretados restritivamente. ${ }^{\mathbf{6}}$

A responsabilidade decorre da liberdade. Como o ser humano é livre para manifestar o seu pensamento e para agir da forma que lhe aprouver, ele também deve ser responsável pelas conseqüências oriundas desses exercícios.

Os preceitos constitucionais que dizem respeito ao dano moral, cogitaram duas hipóteses, a saber:

6 PEREIRA, Caio Mario da Silva. Responsabilidade Civil. 2 ed. Forense, 1990, pág. 60 
ARTIGO 5:

$V$ - é assegurado o direito de resposta proporcional ao agravo, além da indenização por dano material, moral ou a imagem $e$

$X$ - são invioláveis a intimidade, a vida privada, a honra e a imagem das pessoas, assegurado o direito de indenização pelo dano material ou moral decorrente de sua violação.

Assim, pode-se deduzir que a hipótese do item $V$, contempla ofensas causadas através de veículos de comunicação, ou na comunicação social. Vale, por exemplo, para o palestrante ou articulista que procura ridicularizar o profissional que possui posição diversa, ou para os profissionais que têm vedações pelo respectivo Código de Ética.

Já o item $X$ - refere-se ele à "intimidade", "vida privada", "honra" $e$ "imagem" das pessoas, não fazendo nenhuma alusão a inadimplências contratuais ou deficiente prestação de serviços, estes previstos no Código de Defesa do Consumidor, que engloba, igualmente, a má qualidade de produtos. Ao cogitar do dano material e moral, não explicitou o Legislador que a cumulação sempre existiria , pela óbvia razão de que pode ocorrer um, sem que necessariamente haja outro. Ainda, assim, observa-se que adotou um caráter preventivo e se valorou muito a atuação administrativa. ${ }^{7}$

Com o advento da nova Carta Magna, ampliou-se o leque de opções para a propositura de ações nessa área. É o caso do Código de Proteção ao Consumidor (Lei 8.0078, de 11.09.90) que em seu artigo $6^{\circ}$, incisos VI e VII, admitiu a reparação de danos patrimoniais e morais.

Superando as digressões jurisprudenciais que ainda remanesciam, com respaldo no preceito constitucional, o chamado dano moral passou a ser deferido cumulativamente ao dano civil, quando é cabível, é claro. A matéria já está consolidada e sumulada junto ao Superior Tribunal de Justiça - Súmula 37, cujo enunciado diz o seguinte: “São cumuláveis as indenizações por dano material e dano moral oriundos do mesmo fato.”

\section{0 . O CÓDIGO CIVIL E O DANO MORAL}

\footnotetext{
7 ERPEN, Décio Antônio - O dano moral e a desagregação social - São Paulo: Revista dos Tribunais, 1998,n.758, pág. 42
} 
O Código Civil Brasileiro traz um Capítulo 1 (artigos 927 a 954), referente a Obrigação de Indenizar, inserido no Título - IX: Da Responsabilidade Civil, que trata da liquidação das obrigações resultantes de atos ilícitos (anterior 1.537 a 1.553), que se aplica também ao dano moral.

Não obstante ter estabelecido no Artigo 186 que: “Aquele que, por ação ou omissão voluntária, negligência ou imprudência, violar direito e causar dano a outrem, ainda que exclusivamente moral, comete ato ilícito”, o novo Código Civil Brasileiro fez-se omisso quanto à inserção de uma regra geral de reparação do dano moral e parâmetros de sua liquidação, limitando-se a reproduzir o que já se continha mais claramente no Código Civil em vigor.

Dispõe o artigo 927 do Código Civil que:

Artigo 927. Aquele que, por ato ilícito ( arts. 186 e 187), causar dano a outrem, fica obrigado a repará-lo.

Parágrafo único: Haverá obrigação de reparar o dano, independentemente de culpa, nos casos especificados em lei, ou quando a atividade normalmente desenvolvida pelo autor do dano implicar, por sua natureza, risco para os direitos de outrem.

Toda ação deve ser precedida de interesse moral ou econômico e, estando presente o ato ilícito e a lesão ao direito, deve-se observar a cláusula geral do artigo 186 do Código Civil, que se refere também ao dano moral.

À indenização por danos morais deve dar-se caráter exclusivamente compensatório e de acordo com o Artigo 944: “ A indenização mede-se pela extensão do dano.”

De qualquer forma, a legislação em vigor trouxe considerável avanço e mais ampla proteção dos interesses morais, tão contundentemente feridos pelas contingências de vida moderna.

\section{O CÓDIGO DE DEFESA DO CONSUMIDOR E O DANO MORAL}


O Código de Proteção e Defesa do Consumidor - Lei 8.078/90, dispondo sobre todos os direitos e deveres do consumidor e do fornecedor na relação de consumo, tem sido apontado como um dos mais modernos e avançados do mundo e, nele, ficou assegurada, expressamente, a indenização por dano moral, assim dispondo:

\section{“Artigo 6 . São direitos básicos do consumidor:}

VI - A efetiva reparação de danos patrimoniais e morais, individuais, coletivos e difusos.”

A disposição tem fundamento no artigo 5, X, da Constituição Federal de 1988, estabelecido como regra geral e cogente, que assegura a inviolabilidade da honra e imagem das pessoas, em qualquer circunstância, sob pena de indenização por dano material ou moral, e com regra no inciso XXXII que impõe ao Estado o dever de promover a defesa do consumidor.

Todavia, a defesa do consumidor há de ser efetiva e sentida na prática, normalmente sucedida por uma sanção, seja ela pecuniária ou não, sem a qual perderia a sua força impositiva.

O CDC concede a prevenção e proteção do consumidor através de mecanismos vários de controle nas relações de consumo. Se essa prevenção não surtir efeito, assegura a reparação de danos, quer materiais, se for verificado prejuízo atual ou futuro, quer morais, se, caracterizada a violação da honra e da imagem.

Para acentuar esse avanço, garantiu ainda a proteção dos direitos difusos e a reparação do dano moral causado a um número indeterminado de pessoas, legitimando entidades jurídicas públicas ou privadas e órgãos representativos de classe para estarem em Juízo na defesa desses interesses.

O CDC garante o consumidor contra informações do fornecedor de produtos ou serviços que lhe possa causar dano moral, conforme prescreve o artigo 39, inciso VII:

“Artigo 39. É vedado ao fornecedor de produtos ou serviços, dentre outras práticas abusivas: 
VII - repassar informações depreciativas, referente ao ato praticado pelo consumidor no exercício de seus direitos.”

O dano moral sofrido pelo consumidor pode decorrer da exposição ao ridículo ou a qualquer tipo de constrangimento ou ameaça na cobrança de débitos, conforme disposto no caput do Artigo 42:

“Artigo 42. Na cobrança de débitos, o consumidor inadimplente não será exposto a ridículo, nem será submetido a qualquer tipo de constrangimento ou ameaça.”

Com relação a responsabilidade de indenizar, o CDC adotou o princípio da responsabilidade objetiva, uma vez que a responsabilização pelo fato do produto independe da demonstração de culpa. Artigos 12 (fabricantes), 13 (comerciantes) e 14 (fornecedores).

Há exceção, contudo, para os profissionais liberais, reconhecendo-lhes a prerrogativa de apenas responderem pelos danos quando provada a culpa.

Dispõe, também, sobre a regra da responsabilidade solidária se todos concorrerem para a causa do evento danoso (Artigo $7^{\circ}$ Parágrafo único).

“Artigo 7”: (...)

Parágrafo único. Tendo mais de um autor a ofensa, todos responderão solidariamente pela reparação dos danos previstos nas normas de consumo."

As regras do CDC são aplicáveis a entidades públicas ou privadas, se caracterizada a relação de consumo.

Para caracterizar o dano, principalmente o moral, e este ser indenizável, há de ser feita a prova do fato constitutivo de seu direito e que esse procedimento decorreu de sua condição de consumidor. 
Ainda hoje surge a dúvida se uma pessoa jurídica poderá produzir ato agressor ou mesmo ser vítima de dano moral. A primeira objeção que se faz é que a empresa não poderia, enquanto pessoa jurídica, ser agente de dano moral, uma vez que nada pratica, mas sim os seus agentes. Situação ainda mais difícil seria considerar que uma empresa ou instituição pudesse ser objeto de dano moral. Bittar (1992, pág.167) sustenta: que a pessoa jurídica poderá ser sujeito passivo de dano moral e cita como exemplo um sodalício cultural que, uma vez difamado como instituição, pode sofrer prejuízo em seu renome, ou seja, um dano moral, tão reparável como aquele lesivo da pessoa natural. Os agentes da agressão tanto podem ser pessoas físicas ou jurídicas, merecendo especial menção as empresas concorrentes que se valem de meios escusos para garantir maior penetração no mercado consumidor. ${ }^{\mathbf{8}}$

Na doutrina, vem prevalecendo o entendimento de que a pessoa jurídica também pode ser sujeito passivo de dano moral, na explicação de Luiz Felipe Haddad, para a resposta positiva à reparalidade do dano moral sofrido pela pessoa jurídica no tocante ao crédito e a imagem comercial, revela-se especiosa. Quem por falsas notícias, por atitudes alarmistas ou tendenciosas, prejudica a boa imagem de uma empresa perante o público consumidor de determinados produtos, causa sem dúvida, dano à mesma, que não é mensurado apenas no aspecto econômico, mas também em termos morais; não porque uma empresa possa "sofrer" ou "sentir dor”, mas porque seu nome, sua marca, suas características em geral, penosamente construídos pelo labor, se vêem conspurcados de uma hora para outra, com dor e sofrimento, para as pessoas naturais associadas na mesma pessoa jurídica (criada por ficção de direito), confundindo a personalidade da empresa com a de seus sócios. ${ }^{9}$

A seu turno, a jurisprudência mais atualizada vem se orientando no sentido de que as entidades coletivas estão dotadas dos atributos de reputação e conceito perante a sociedade, e, por conseguinte, são passíveis de difamação, desde que a manifestação possa abalar tais atributos, admitindo assim a reparação por dano moral sofrido pela pessoa jurídica. ${ }^{\mathbf{1 0}}$

Assim, todos os meios de hospedagem, principalmente os estabelecimentos hoteleiros, podem ter sua reputação, bom nome, boa fama, conceito alheio atingidos e a imagem danificada, acarretando a diminuição da posição jurídica de que desfruta.

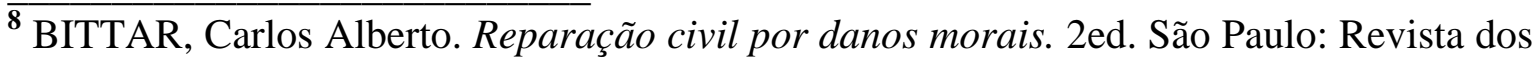
Tribunais, 1992, pág.167.

${ }^{9}$ CAHALI, Yussef Said. Dano Moral. 2 ed. São Paulo:Revista dos Tribunais, 2000, pág. 348

${ }^{10}$ CAHALI, Yussef Said. Dano Moral. 2 ed. São Paulo:Revista dos Tribunais, 2000, pág. 34.
} 


\section{II - DA RESPONSABILIDADE CIVIL}

\section{COMENTÁRIOS E OBSERVAÇÕES}

A palavra "responsabilidade” se origina do verbo "respondere”, que contém a raiz latina de "spondeo" que significa a obrigação que alguém tem de arcar com as conseqüências jurídicas de sua atividade, "é o dever que tem a pessoa de prestar contas de seus atos, ou seja, tornar-se garantidor de alguma coisa.”

A responsabilidade civil consiste em reparar um dano decorrente de uma culpa ou de uma circunstância legal que a justifique, como a culpa presumida ou circunstância meramente objetiva.

A regra básica é que a responsabilidade civil pressupõe idéia de culpa, no tocante ao descumprimento de uma obrigação por uma das partes da relação jurídica. Mas há exceções em que a responsabilidade civil é objetiva , isto é, independe de culpa, como no caso de responsabilidade decorrente do Código de Defesa do Consumidor.

A teoria da responsabilidade civil está construída sobre a reparação do dano. Tal princípio emerge do Artigo 186 do Código Civil Brasileiro: Aquele que por ação ou omissão voluntária, negligência ou imprudência, violar direito e causar dano a outrem, ainda que exclusivamente moral, comete ato ilícito" e do Artigo 927: “Aquele que por ato ilícito (arts. 186 e 187), causar dano a outrem, fica obrigado a repara-lo. Parágrafo único: Haverá obrigação de reparar o dano, independentemente de culpa, nos casos especificados em lei, ou quando a atividade normalmente desenvolvida pelo autor do dano implicar, por sua natureza, risco para os direitos de outrem.

A responsabilidade civil enfatiza o dever de indenizar sempre que os elementos caracterizadores do ato ilícito estiverem presentes. Na esfera consumerista, deve desempenhar tanto a tarefa de ressarcir os danos sofridos por algum lesado, quanto a restabelecer o status quo ante, sendo, acima de tudo, um desestímulo a futuras violações. 
É oportuno trazer à reflexão as ponderações de Caio Mário da Silva Pereira para o tema: "para determinação da existência do dano, como elemento objetivo da responsabilidade civil, é indispensável que haja ofensa a um bem jurídico.”

\section{ELEMENTOS E ESPÉCIES DE RESPONSABILIDADE}

Para caracterização da responsabilidade civil, faz-se necessária a presença de três elementos: a) ação do agente lesivo; b) nexo causal; c) dano.

Ação lesante é a ação - comissiva ou omissiva - qualificada juridicamente. Resulta do comportamento ilícito praticado pelo agente ativo(lesante) da relação jurídica. Há hipóteses em que, ainda que se proceda de forma legal, dever-se-á reparar o dano quando o ressarcimento desse não se liga à idéia de culpa, deslocando a responsabilidade nela fundada para o risco.

O nexo causal é o liame existente entre o ato lesivo e o dano causado ao agente lesado (agente passivo). Diz-se que o nexo causal é o fato gerador da responsabilidade, pois o dever de reparar não existirá sem que haja o vínculo entre a ação e o dano. O nexo representa uma relação necessária entre o evento danoso e a ação que o produziu, de forma que essa seja tida como sua causa. Há que se atentar que o dano não precisa resultar imediatamente do fato que o produziu. Basta provar que o dano não ocorreria se o fato não tivesse ocorrido.

O dano, por sua vez, é o resultado dessa prática abusiva. No entender de Maria Helena Diniz, é o dano moral ou patrimonial causado à vítima por ato comissivo ou omissivo do agente ou de terceiro por quem o imputado responde, ou por um fato de animal ou coisa a ele vinculada. Não pode haver responsabilidade civil sem dano, que deve ser certo, a um bem ou interesse jurídico, sendo necessária a prova real e concreta dessa lesão. ${ }^{11}$

\footnotetext{
$\overline{11}$ DINIZ, Maria Helena. Curso de Direito Civil Brasileiro, $7^{\circ}$. vol. Responsabilidade Civil. São Paulo: Saraiva, 1999.
} 
A responsabilidade civil pode apresentar-se sob diferentes espécies, conforme a analisa. Assim sendo, poderá ser classificada :

1) quanto ao seu fato gerador: a responsabilidade será contratual ou extracontratual (aquiliana). Contratual quando advém de uma inexecução contratual. Extracontratual quando resulta da violação de dever legal de não fazer, concernente aos direitos reais ou de personalidade. É a lesão ao direito do outro, sem que preexista entre o lesionador e o lesado qualquer relação jurídica. O ônus de provar a culpa do agente caberá à vítima, lembrando que essa responsabilidade delitual baseada na culpa abrangerá, também, a responsabilidade sem culpa fundada no risco.

2) em relação ao seu fundamento: a responsabilidade civil poderá ser subjetiva ou objetiva. Subjetiva se o dano à pessoa se justificar pela culpa ou dolo, na ação ou omissão do agente lesivo. Dessa forma, será imprescindível provar a culpa do agente para surgir o dever de reparar o dano. E será objetiva quando fundada no risco, ou seja, a obrigação de reparar o dano causado à vítima ou a seus bens independerá da modalidade da culpa, sendo irrelevante a conduta culposa ou dolosa do agente causador do dano, bastando, tãosomente, a existência do nexo causal entre o prejuízo sofrido e a ação do agente.

3) relativamente ao agente: a responsabilidade de quem causou o dano poderá ser direta ou indireta. Se o ato lesivo for praticado pelo próprio sujeito ativo, será tida como direta. Porém, se a responsabilidade se origina de ato de terceiro, vinculado ao agente, fato animal ou coisa inanimada sob sua guarda, será tida por indireta ou complexa.

\section{3 - FUNÇÃO DA RESPONSABILIDADE CIVIL}

A função primordial da responsabilidade civil é a de obrigar o agente ativo da relação jurídica a reparar os prejuízos causados ao lesado, independentemente do dano ter sido gerado pelo cumprimento ou descumprimento de uma obrigação. O que se tem como indispensável é o restabelecimento do equilíbrio da relação. 
O dano moral encontra guarida no âmbito da responsabilidade civil, que há muito tempo agasalha o princípio geral de direito sobre o qual se funda a obrigação de indenizar.

O ser humano, porque dotado de escolha e de discernimento, deve responder por seus atos. A liberdade e a racionalidade, que compõem a sua essência, trazem-lhe, em comportamento, a responsabilidade por suas ações, no âmbito do direito, ou seja, a responsabilidade é corolário da liberdade e da racionalidade.

Hoje em dia, a responsabilidade civil é um ponto fundamental para que a reparação por danos morais sofridos se efetive. Ela nasce da iliceidade da conduta do agente , de sua conduta que contrasta com os dispositivos normativos relativos à matéria.

A reação legal da responsabilidade civil surge com a perda ou diminuição do patrimônio lesado ou dano moral à pessoa, devido à ilicitude da ação do autor da lesão ou do risco. Tal responsabilidade tem função indenizatória ou reparadora, servindo para assegurar os direitos inerentes aos indivíduos e configurando-se como sanção civil de cunho compensatório, mediante reparação do dano causado.

Maria Helena Diniz ensina que a responsabilidade civil constitui uma sanção civil, por decorrer de infração de norma de direito privado, cujo objetivo é o interesse particular ,e, em sua natureza, é compensatória, por abranger indenização ou reparação de dano causado por ato ilícito, contratual ou extracontratual, e por ato ilícito. ${ }^{12}$

Embora a dor sofrida oriunda de um dano à moral seja “indenizável”, sabe-se que a prestação pecuniária dela decorrente tem meramente função satisfatória pelas vantagens que o dinheiro pode proporcionar, procurando apenas amenizar os males e sofrimentos, ou seja, compensa-se até certo ponto o dano injustamente causado, visto que o bem moral é insuscetível de aferição econômica. O valor pecuniário terá caráter concomitantemente satisfatório para a vítima e punitivo para o lesante, resultando numa função de justiça corretiva ou sinalagmática, por conjugar, simultaneamente, a natureza satisfatória para a vítima e a natureza penal para o lesionador.

12 DINIZ, Maria Helena. Curso de Direito Civil Brasileiro, $7^{\circ}$. vol. Responsabilidade Civil. São Paulo: Saraiva, 1999. 
Na avaliação do dano moral, o órgão judicante deverá estabelecer uma reparação eqüitativa, baseada na culpa do agente, na extensão do prejuízo causado e na capacidade econômica do responsável .

O dano moral pode ser demonstrado por todos os meios de prova admitidos em Direito, inclusive pelas presunções estabelecidas para determinadas pessoas da família da vítima.

\section{5 . A RESPONSABILIDADE CIVIL NAS RELAÇÕES DE CONSUMO}

O Artigo $5^{\circ}$. da Lei Maior, no seu inciso XXXII, dispõe que o Estado promoverá a defesa do consumidor, garantindo-lhe essa quando sentir-se prejudicado por um ato ilícito praticado pelo fornecedor.

Em 1991, entrou em vigor a Lei $n^{\circ}$ 8.078/90, baseando-se na Constituição Federal de 1988, trazendo garantias aos direitos do consumidor e defesa a outros direitos peliculares das relações de consumo.

Apenas essas serão regidas pelo Código de Defesa do Consumidor. Quanto às regras de consumo, revogam-se as normas do Código Civil, Código Comercial e demais Leis Extravagantes, prevalecendo a norma específica do Código de Defesa do Consumidor.

As relações civis e comerciais que não se enquadram no conceito de relações de consumo continuam a ser reguladas por suas leis especificas, não tendo havido revogação ou alteração das disposições dos Códigos Civil e Comercial, nem de leis extravagantes que disciplinam normas sobre as relações jurídicas civis ou comerciais. Ao revés, naquilo em que o Código de Defesa do Consumidor for omisso, são aplicáveis às relações de consumo as disposições dos Códigos Civil, Processual Civil, Penal, Processual Penal e demais leis extravagantes, por extensão ou analogia.

A responsabilidade civil do fornecedor representa um inovador e significativo avanço na proteção ao consumidor, já que objetiva repará-lo dos prejuízos causados pelo fornecimento de produtos ou serviços defeituosos. Ela torna-se fundamental quando posto 
à esfera do consumidor um produto ou serviço defeituoso que venha lhe causar algum dano. Não cabe ao fornecedor de produtos ou serviços, devidamente individualizado no Artigo $3^{\circ}$. do Código de Defesa do Consumidor, alegar que inexiste culpa com relação ao dano ocorrido, uma vez que sua responsabilidade, por determinação do novo Código, tornou-se objetiva, independendo de averiguação de dolo ou culpa.

A regra geral que se deve presidir à responsabilidade civil fundamenta-se na idéia de culpa, mas não é o suficiente para atender às imposições do progresso. Cumpre ao legislador fixar os casos em que deverá ocorrer a obrigação de reparar, independentemente daquela noção. Não será sempre que a reparação do dano se abstrairá do conceito de culpa, a não ser quando o autorizar a ordem jurídica positiva. Havendo a relação jurídica, a causa, a conseqüência e o nexo causal, não se discute a responsabilidade do fornecedor pelo fato do produto ou serviço prestado.

Quanto aos elementos da relação de consumo, imprescindível se faz a identificação da figura do fornecedor. Na visão de Eduardo Gabriel Saad, o sujeito ativo e lesante da relação de consumo caracteriza-se desta forma: é toda pessoa física ou jurídica que oferece o serviço, seja uma entidade publica, ou uma entidade privada; nacional ou internacional; e até despersonalizada, mas se ofereceu produto ou serviço com defeito, será responsabilizada civilmente e responderá pelo ato. ${ }^{13}$

O consumidor, por sua vez, é o agente passivo e lesado da relação, definido no Artigo $2^{\circ}$ do Código de Defesa do Consumidor. Trata-se de toda e qualquer pessoa física ou jurídica que venha a utilizar bens ou serviços oferecidos pelo fornecedor. A pessoa jurídica comportará o pólo passivo da relação de consumo quando os produtos ou serviços adquiridos por ela não estiverem aptos para sua utilização, trazendo-lhe prejuízos.

Na análise do Artigo 14, Parágrafo $4^{0}$ do Código de Defesa do Consumidor, verificase que não cabe ao fornecedor se eximir da obrigação de reparar os gastos sofridos pelo consumidor. A partir do momento em que o fornecedor se propõe a colocar no mercado produto ou serviço e este não é adequado, acarretando dano ao consumidor adquirente, o fornecedor é obrigado a arcar com as conseqüências do ato danoso. Há, no entanto, circunstâncias em que o fornecedor se eximirá de reparar o dano à moral do consumidor.

13 SAAD, Eduardo Gabriel 
São os casos de excludente de responsabilidade, que serão tratados posteriormente.

\section{6 - RESPONSABILIDADE CIVIL DOS HOTELEIROS OU PROPRIETÁRIOS DOS MEIOS DE HOSPEDAGEM}

O Artigo 932 do Código Civil, em seu inciso IV, dispõe que são também responsáveis pela reparação os donos de hotéis, hospedarias, casas ou estabelecimentos, onde se albergue por dinheiro, mesmo para fins de educação, pelos seus hóspedes, moradores e educando.

Também presume a responsabilidade pelos prejuízos causados pelos hóspedes, seja a terceiros, seja a um outro hóspede. Essa culpa, tanto pode ser "in vigilando" como "in eligendo". A primeira, em razão do dono do hotel ser obrigado a uma vigilância permanente do comportamento de seus hóspedes, a segunda, porque impõe ao hoteleiro uma certa disciplina na escolha dos hóspedes e funcionários que admite. 14

A culpa também poderá ser:

- “in custodieno”- falta de cautela ou omissão;

- “in nommitendo”- deixar de fazer, omitir-se, abster-se, negligência;

- “in commitendo”- imprudência

Os casos mais freqüentes são aqueles que prevêem a responsabilidade dos donos de hotéis pelos furtos e roubos que forem perpetrados por pessoas empregadas ou admitidas, visitantes, fornecedores, etc., no âmbito do hotel, contra os hóspedes . Dispositivos do Código Civil atribuem aos hospedeiros a responsabilidade, como depositários, pelas bagagens dos viajantes, pois trata-se de responsabilidade contratual equiparada ao depósito necessário. Tal responsabilidade só cessa nos casos de roubos com violência , assalto à mão armada, ou provando-se que não podiam ser evitados ou, ainda, que a culpa foi exclusiva do hóspede. Observe que o depositário não responde pelos casos de força maior, mas, para que lhe valha a escusa, terá de prová-los. Exemplo:

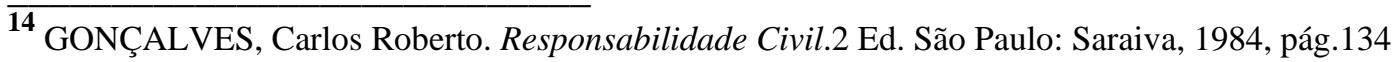


HOTEL- RESPONSABILIDADE CIVIL- Desaparecimento de bagagem de hóspede - Hipótese de depósito necessário- Indenização devida Aplicação do artigo 1.284 do Código Civil. Por força do depósito necessário previsto no art. 1.284 do CC, cumpre ao hóspede no local, bem como a de seus bem a que se achem em poder dele, sendo irrelevante o fato de os bens desaparecidos não serem de uso próprio, eis que caracterizados como bagagens. ${ }^{15}$

No caso do depósito necessário (bagagens), poderá o hoteleiro ter excluída tal responsabilidade se provar que o prejuízo não poderia ter sido evitado (Código Civil, Artigo 1.285, I); força maior ou caso fortuito, como no caso de roubo à mão armada ou violências semelhantes (Código Civil, Art.1.285, II); e culpa exclusiva do hóspede.

Já no depósito voluntário (jóias guardadas no cofre do hotel), poderá o hoteleiro invocar a excludente da forca maior, em caso de roubo à mão armada, provando a inexistência de negligência de sua parte e que o fato não pôde ser afastado ou evitado.

A tendência atual da doutrina e jurisprudência, pendente em ampliar o acesso à reparalidade plena, é aceitar a teoria do risco, ou seja, aceitar a admissão da responsabilidade sem culpa pelo exercício da atividade que, por sua natureza, representa risco para os direitos de outrem.

O dispositivo que trata desse entendimento é o Artigo 927, Parágrafo único, ao estabelecer que “haverá obrigação de reparar o dano, independentemente de culpa, nos casos especificados em lei, ou quando a atividade normalmente desenvolvida pelo autor do dano implicar, por sua natureza, riscos para os direitos de outrem”.

O Artigo 931, a despeito de parecer tratar de relações de consumo, retrata o acolhimento da responsabilidade objetiva, fundada na teoria do risco : “Ressalvados outros casos previstos em lei especial, os empresários individuais e as empresas respondem independentemente de culpa pelos danos causados pelos produtos postos em circulação”.

Nesse caso, prevê o Código Civil que o empresário responderá de forma objetiva isto é, sem que seja necessária a verificação da culpa - pelos danos que forem causados em função do produto ou serviço, bastando tão-somente demonstrar a existência do dano.

$\overline{15}$ Revista dos Tribunais, São Paulo: 1996, pág, 632 
De qualquer forma, indenizará também por danos morais se restar comprovada a existência do dano. 
III - A APLICAÇÃO DO CÓDIGO DE DEFESA DO CONSUMIDOR NO TURISMO (COM ÊNFASE NO CONSUMIDOR DOS MEIOS DE HOSPEDAGEM)

O Código Brasileiro de Defesa do Consumidor é aplicado toda vez que se estiver diante de uma relação de consumo, independente de ramo de Direito - público e privado, contratual e extracontratual, material e processual, pois é uma lei de ordem pública. Assim, em se tratando do sistema de turismo e hospitalidade, sendo este uma atividade de livre iniciativa, a sua relação com o consumidor também é regida pela Lei n. 8.078/1990 Código de Defesa do Consumidor.

O Artigo $1^{\circ}$. O presente Código estabelece normas de proteção e defesa do consumidor, de ordem pública e interesse social, nos termos do Artigo $5^{\circ}$ inciso XXXII, 170, inciso V, da Constituição Federal e Artigo 48 de suas Disposições Transitórias.

“A lei de ordem Pública é aquela cuja obediência é obrigatória e dispositivo de ordem substantivo e instrumental, não pode ser desatendida ou relevada pelas partes e, principalmente pelo Juiz." 16

Durante muitos anos o consumidor brasileiro esteve em posição desfavorável para reivindicar seus direitos perante o lhe era imposto e determinado pelo fornecedor. Não havia consenso entre as partes, bem como nenhuma lei específica para determinar os direitos dos consumidores e os deveres dos fornecedores. No turismo e hospitalidade não era diferente e até hoje percebe-se as dificuldades prevenir e reprimir abusos ante a fragilidade do turista/hóspede/consumidor ante o poderio econômico do fornecedor (Companhias Aéreas, Hotéis, Operadoras de Viagens, Agencias, etc.).

Na visão de Diniz (1988, pág.347) o Código de Defesa do Consumidor é o mais moderno do mundo, por conter normas de ordem pública, pretendendo equilibrar as relações entre fornecedores de produtos e serviços e consumidores, outorgando instrumentos de defesa idôneos à satisfação de seus interesses, sancionando as práticas abusivas, impondo a responsabilidade objetiva dos fornecedores. Diz ainda que sua elaboração é indubitavelmente uma conquista constitucional para proteger os interesses patrimoniais dos adquirentes de produtos e serviços, mediante a imposição de responsabilidade civil, penal e administrativa para os fornecedores ou prestadores de serviços. ${ }^{17}$ 
Conforme já citado, o CDC veio, estabelecer uma nova ordem na relação de consumo entre as partes contratantes.

Entende-se por relação de consumo, aquela em que existem duas partes fundamentais, ou seja, o Fornecedor e o Consumidor, que contratam um produto ou uma prestação de serviço e envolvem a satisfação de uma necessidade privada do consumidor (destinatário final).

\section{CONCEITOS BÁSICOS}

\section{a) consumidor:}

Numa visão geral, é qualquer pessoa que contrata para consumo final, em benefício próprio ou de outrem, a aquisição ou locação de bens ou prestação de um serviço.

O Código de Defesa do Consumidor traz em seu bojo três conceitos de consumidor. O primeiro deles está expresso no art. $2^{\circ}$, verbis:

“Artigo $2^{\circ}$. Consumidor é toda pessoa física ou jurídica que adquire ou utiliza produto ou serviço como destinatário final ”.

Observa-se a presença de dois requisitos: a aquisição ou utilização de bem ou serviço e a destinação privada do bem adquirido ou utilizado. Este último requisito exclui do conceito de consumidor o industrial, o comerciante, o intermediário ou atravessador.

Dessa forma, a pessoa jurídica somente será considerada legalmente como consumidor quando adquirir ou utilizar como destinatária final. De qualquer sorte, o CDC consagrou a proteção do consumidor pessoa jurídica, refletindo um avanço em toda sociedade de consumo

16 (CARVALHO NETO, Frederico da Costa. Código de Defesa do Consumidor. In Ônus da Prova . São Paulo: Juarez de Oliveira, 2002, pág. 124)

17 DINIZ, Maria Helena. Curso de Direito Civil Brasileiro, $7^{\circ}$. vol. Responsabilidade Civil. São Paulo: Saraiva, 1988, pág. 347. 
No Artigo 17, encontra-se o segundo conceito de consumidor, que trata dos acidentes sofridos por terceiros, estranhos à relação jurídica de consumo. Tal Artigo dispõe:

“Artigo 17. Para os efeitos dessa Seção, equiparam-se aos consumidores todas as vítimas do evento."

Nesse artigo o conceito é alargado a fim de acolher todas as vítimas do evento, em função da gravidade dos acidentes de consumo que acarretam riscos à saúde e à integridade física de consumidores e terceiros.

Trata-se do novo âmbito da tutela do consumidor: a vítima do acidente de consumo que, em virtude do disposto no artigo, passa a ser equiparada a consumidor. Nesse caso não importa se o tutelado qualifica-se como destinatário final do produto ou se houve a sua participação na relação de consumo. Sua proteção está condicionada apenas ao fato de que tenha sido atingida em sua incolumidade físico-psíquica ou econômica pelos efeitos do acidente de consumo.

O terceiro conceito, incluído no Capítulo das "Práticas Comerciais” e também fazendo referência ao Capítulo da "Proteção Contratual”, é assim disciplinado no Código de Defesa do Consumidor:

“Artigo 29 . Para os fins deste Capítulo e do seguinte, equiparam-se aos consumidores todas as pessoas determináveis ou não, as práticas nele previstas”.

Esse artigo equiparou aos consumidores todas as pessoas determináveis ou não, expostas às práticas comerciais, gozando da mesma proteção concedida ao consumidor direto. Desse modo, aqueles que não são partes em um contrato de compra e venda ou de prestação de serviços, mas que podem vir a ser, estão protegidos da mesma forma que os consumidores no tocante às praticas comerciais e contratuais. ${ }^{\mathbf{1 8}}$

18 ROCHA, Sílvio Luís Ferreira. Responsabilidade Civil do Fornecedor pelo Fato do Produto no Direito Brasileiro. São Paulo: Revista dos Tribunais, 1992, pág. 70. 


\section{b) fornecedor:}

É toda pessoa física autônoma ou jurídica (empresa) que exerce habitualmente atividade na cadeia de produção e comercialização de produtos ou serviços à disposição do consumidor.

O nosso Código de Defesa do Consumidor definiu o que seja fornecedor, assim dispondo:

Artigo $3^{\circ}$. Fornecedor é toda pessoa física ou jurídica, pública ou privada, nacional ou estrangeira, bem como os entes despersonalizados, que desenvolvem atividades de produção, montagem, criação, construção, transformação, importação, exportação, distribuição, ou comercialização de seus produtos ou prestação de serviços.

A expressão “atividade” descrita acima refere-se a atividade negocial, que é a pratica reiterada desses atos, de modo organizado, visando a uma unidade econômica e permanente.

São tidos como fornecedores todos quantos ofertem produtos e serviços no mercado de consumo, sempre com vistas a atender às necessidades dos consumidores, sendo de relevância a distinção que se deve fazer entre as várias espécies de fornecedor nos casos de responsabilização por danos causados aos consumidores, ou mesmo para que os próprios fornecedores acionem na via regressiva e em cadeia da mesma responsabilização.

Na definição dada pelo Código de Defesa do Consumidor do que seja fornecedor, podemos detectar pelo menos três figuras: a) o fornecedor ou produtor real: é o realizador do produto, a pessoa física ou jurídica que participa do processo de fabricação ou produção do produto acabado, de uma parte componente ou de matéria-prima sob sua responsabilidade; b) o fornecedor aparente: é quem, embora não tenha participado do processo de fabricação ou produção é tido como tal pela existência no produto do seu nome, marca ou outro sinal; é essa suposição feita pelo consumidor de que o produto foi fabricado por aquele fornecedor que justifica e fundamenta a extensão do conceito de fornecedor a tais pessoas, sejam elas físicas ou jurídicas; e c) o fornecedor presumido: é aquele que importou os produtos, ou ainda, vende os produtos sem identificação clara do seu fabricante, produtor, importador ou construtor 
Tem-se, por conseguinte, “que fornecedor é qualquer pessoa física ou seja, qualquer um que, a título singular, mediante desempenho de atividade mercantil ou civil e de forma habitual, ofereça no mercado produtos ou serviços ,e a jurídica, da mesma forma, mas em associação mercantil ou civil e de forma habitual." 19

\section{c) serviço}

É qualquer atividade fornecida ao consumidor, mediante remuneração.

$\mathrm{O}$ par. $2^{\circ}$ do artigo $3^{\circ}$ dispõe que: Serviço é qualquer atividade fornecida no mercado de consumo, mediante remuneração, inclusive as de natureza bancária, financeira, de crédito e securitária, salvo as decorrentes das relações de caráter trabalhista.

A expressão "mediante remuneração" deve ser entendida não somente como a remuneração efetuada diretamente pelo consumidor ao fornecedor. Abrange também a remuneração, o benefício comercial indireto advindo da prestação de serviços supostamente gratuitos, a título de demonstração ou promoção, bem como a remuneração embutida em outros custos. $^{20}$

Para se caracterizar serviço, basta que a atividade seja remunerada, mesmo que esporádica e não habitual. A atividade denominada serviço público também está perfeitamente enquadrada no conceito geral de serviço, posto que é atividade remunerada oferecida no mercado de consumo.

\section{d) produto}

É qualquer bem, móvel ou imóvel, material ou imaterial. A definição de produto está explícita no Parágrafo único $1^{\circ}$ do Artigo $3^{\circ}$ do CDC.

\section{e) relação de consumo}

19 FILOMENO, José Geraldo de Brito. Código de defesa do consumidor comentado pelos autores do anteprojeto. 7.ed. Rio de Janeiro: Forense Universitária, 200, pág. 39.

20 ROCHA, Sílvio Luís Ferreira. Responsabilidade Civil do Fornecedor pelo Fato do Produto no Direito Brasileiro. São Paulo: Revista dos Tribunais, 1992, pág. 73 
Entende-se por relação de consumo aquela em que existem duas partes fundamentais, ou seja, o Fornecedor e o Consumidor, que contratam um produto ou uma prestação de serviço. É o vínculo (jurídico) que se estabelece entre as partes e envolve a satisfação de uma necessidade privada do consumidor - destinatário final - “A relação de consumo envolve sempre, em um dos pólos, alguém enquadrável no conceito legal de fornecedor $\left(C D C\right.$ art. $\left.3^{\circ}\right)$ e, no outro, no de consumidor (CDC, art. $\left.2^{\circ}\right) .^{21}$

\section{PRINCÍPIOS:}

A Política Nacional das Relações de Consumo rege-se por uma série de princípios e, segundo o Artigo $4^{\circ}$ do Código de Proteção e Defesa do Consumidor, tem por objetivo o atendimento das necessidades dos consumidores, o respeito, a dignidade, saúde e segurança, a proteção de seus interesses econômicos, a melhoria da sua qualidade de vida, bem como a transparência e harmonia das relações de consumo.

No contexto da proteção dos direitos do consumidor/turista, as decisões dos tribunais brasileiros fundamentam-se, muitas vezes, nos princípios fundamentais da Lei consumerista.

Tais princípios foram estabelecidos nos Artigos $1^{\circ}$ ao $7^{\circ}$ do Código de Defesa do Consumidor, sendo que os demais e subseqüentes foram elaborados como uma espécie de descrição daqueles princípios contidos nos sete primeiros, de modo a torná-los efetivos e operacionais, quais sejam:

\section{a) Princípio da vulnerabilidade}

A primeira justificativa para o surgimento da tutela do consumidor se dá através do reconhecimento de sua vulnerabilidade perante a figura do fornecedor, ou seja, todo consumidor representa a parte fraca da relação jurídica de consumo. 
"Este princípio possui fundamental importância para o nosso sistema consumerista, emanado dele todo o Código, posto que a vulnerabilidade é um traço universal de todos os consumidores, ricos ou pobres, educadores ou ignorantes, crédulos ou espertos”. ${ }^{22}$

Havendo, desse modo, a crescente necessidade de correção jurídica para minimizar a disparidade entre os sujeitos da relação de consumo.

O Código, ao dar tratamento diferenciado aos sujeitos da relação de consumo, conferindo maiores prerrogativas ao consumidor, nada mais fez do que aplicar e obedecer ao princípio constitucional da isonomia, tratando desigualmente partes desiguais, [...] isto porque devem os consumidores ser tratados de forma desigual pela lei, a fim de que atinja, efetivamente, a igualdade real em obediência ao dogma constitucional da isonomia (art. $5^{\circ}$, caput, $\mathrm{CF}$ ), pois devemos desiguais ser tratados desigualmente na exata medida de sua desigualdade (isonomia real, substancial e não meramente formal). ${ }^{23}$

A vulnerabilidade do consumidor pode ser demonstrada, dentre outros, a partir de fatores como:

1) ordem técnica - o consumidor desconhece os meios de produção da fabricação de produtos e da prestação de serviços. Cabe ao fornecedor, unilateralmente, decidir e escolher a maneira ideal para fabricar o produto ou prestar o serviço. O consumidor terá a opção, apenas, de adquirir o que foi decidido pelo fornecedor no mercado de consumo;

2) capacidade econômica - na maioria das vezes, o fornecedor detém "poder econômico" que o torna "forte" e, automaticamente, “fragiliza” o consumidor, [...] entende-se que o consumidor é vulnerável no mercado de consumo, isto é, quando sujeita-se às práticas de oferta, publicidade e de fornecimento dos produtos e serviços, bem como os contratos referentes à aquisição deles. $^{24}$

21 COELHO, Fábio Ulhoa. Manual de Direito Comercial. 11 ed. São Paulo: Saraiva, 1993, pág. 81

${ }^{22}$ NERY JUNIOR, Nelson. Código de Defesa do Consumidor: Comentado pelos autores do anteprojeto. Rio de Janeiro. Forense Universitária, 2001, pág. 84/5

${ }^{23}$ NERY JÚNIOR, Nelson. Os Princípios gerais do Código Brasileiro de Defesa do Consumidor. Revista do Direito do Consumidor, São Paulo: Revista dos Tribunais, v.33, jan-mar/2000, pág.53

${ }^{24}$ LISBOA, Roberto Senise. Responsabilidade civil nas relações de consumo. São Paulo: Universidade de São Paulo, 2000, pág. 355. 


\title{
b) - Princípio da boa-fé:
}

As relações de consumo que possam estar sujeitas a influências malignas decorrentes da prática de concorrência desleal, abuso de poder econômico ou violação ilícita das regras sobre propriedade industrial ou direito sobre marcas e patentes são repudiadas pelo princípio da boa-fé.

\begin{abstract}
A boa-fé subjetiva diz respeito à ignorância de uma pessoa acerca de um fato modificador, impeditivo ou violador de seu direito. É, pois a falsa crença acerca de uma situação pela qual o detentor do direito acredita em sua legitimidade, porque desconhece a verdadeira situação [...]. Já a boa-fé objetiva, que é a que está presente no CDC, pode ser definida, grosso modo, como sendo uma regra de conduta, isto é, o dever das partes de agir conforme certos parâmetros de honestidade e lealdade, a fim de estabelecer o equilíbrio nas relações de consumo. ${ }^{25}$
\end{abstract}

A boa-fé objetiva busca estabelecer equilíbrio de interesses entre as partes, vetando o desrespeito, abusos ou lesões entre os contratantes.

\section{b)Princípio da confiança}

O Código de Defesa do Consumidor busca proteger os interesses sociais das partes envolvidas, destacando a “confiança” depositada no vínculo, na expectativa e na boa-fé das partes contratantes. A confiança despertada no consumidor pode surgir em decorrência de informações dadas pelo fornecedor.

$\mathrm{O}$ artigo 30 do CDC legisla sobre a publicidade e declara principalmente que "informação ou publicidade, suficientemente precisa, obriga o fornecedor que a fizer veicular ou dela se utilizar e integra o contrato que vier a ser celebrado”.

Portanto, o fornecedor é responsável pela informação ou publicidade veiculadas, e, por “integrar o contrato”, o consumidor poderá exigir o seu cumprimento forçado, de acordo com o artigo 35 do CDC.

\footnotetext{
${ }^{25}$ RIZZATO NUNES, Luiz Antônio. Comentários ao Código de Defesa do Consumidor. Direito Material (art. $1^{\circ}$ a 54). São Paulo: Saraiva, 2000, pág. 53
} 
A publicidade veiculada pelo fornecedor gera expectativa do consumidor em relação ao produto/serviço que pretende consumir.

Em contrapartida, cabe ao fornecedor retribuir essa “confiança” depositada, por meio da execução ou fornecimento do produto/serviço informado ao consumidor. Saliente-se que todas as informações veiculadas na publicidade, segundo o CDC, integram o contrato a ser celebrado.

A teoria da confiança busca amparar as expectativas legítimas do contratante, ora consumidor, que surgem em decorrência das declarações e obrigações assumidas pelo contratado, então fornecedor. As jurisprudências nacionais já vêm amparando suas decisões na teoria da confiança em relação ao turista/consumidor.

EMENTA: INDENIZAÇÃO - PUBLICIDADE ENGANOSA - TEORIA DA CONFIANÇA - PRESTAÇÃO DE SERVIÇO - AGENNCIA DE VIAGEM - DIREITO DE REGRESSO - CÓDIGO DE DEFESA DO CONSUMIDOR. A evolução do pensamento jurídico no âmbito do acordo de vontades representou o deslocamento do centro de gravidade da teoria contratual da autonomia de vontade - que refletia a ideologia do Estado Liberal, cujo auge foi no século passado, vindo a nortear o CC pátrio - para o interesse social - em consonância com o Estado Social, que se afirma, dentro do ordenamento brasileiro, no Código de Defesa do Consumidor. A teoria da confiança atribui responsabilidade àquele que, por seu comportamento na sociedade, gera no outro contratante justificada expectativa no adimplemento de determinadas obrigações. A publicidade integra o contrato, de acordo com o Art. 30 da Lei 8078/90. Se o consumidor é incitado a firmar contrato com determinado prestador de serviço, persuadido por publicidade de associação à qual é filiado e que alardeia segurança e garante bom atendimento por parte de seus associados, e é enganado, uma vez que a empresa prestadora de serviço descumpre a avença, por passar por sérias dificuldades financeiras, poderá exigir o ressarcimento dos prejuízos que sofreu ao fechar aquele contrato. A associação que veiculou publicidade poderá responder, frente ao efeito vinculado desta, pelos danos causados por entidade filiada que não gozava de idoneidade financeira, tendo direito de regresso perante ela. 26

\footnotetext{
26 TAMG - Apelação n. 220126-9, $3^{\text {a }}$ Câmara Civil do TAMG, Belo Horizonte, Rel. Juiz Wander Marotta, v. u., 14.08.96, DJ 23.10.96, ERJTAMG 64/250
} 
Em face da repercussão nacional obtida por tal decisão, a citada associação vem tendo maior cautela na fiscalização de seus associados, de modo a, somente após a constatação da veracidade das informações divulgadas, poder "garantir” os serviços por eles prestados ao consumidor vulnerável.

\section{d) Princípio da transparência}

O princípio da transparência, expresso no caput do Artigo $4^{\circ}$ do CDC, estabelece de forma clara e informativa a relação contratual entre consumidor e fornecedor, visando à idéia de reequilíbrio de forças e estabelecimento de uma justiça contratual entre as partes contratantes. Assim, este princípio será rematado pelo princípio do dever de informar, previsto no inciso III do Artigo $6^{\circ}$ e, também, no Artigo 46, que estabelece a necessidade de prévia apresentação do conteúdo do contrato.

O direito à informação se não restringe apenas à fase pré-contratual, mas também ao conteúdo das relações contratuais, já que as informações veiculadas ou requeridas integram o conteúdo do contrato.

Eis porque institui o CDC um novo e amplo dever para o fornecedor, o dever de informar ao consumidor não só sobre as características do produto ou serviço, como também sobre o conteúdo do contrato. Pretendeu, assim, o legislador evitar qualquer tipo de lesão ao consumidor, sem ter o conhecimento do conteúdo do contrato, das obrigações que estará assumindo, e que poderia vinculá-lo à obrigação que não pode suportar ou que simplesmente não deseja. 27

\section{e) Princípio da hipossuficiência}

O Código de Defesa do Consumidor estabelece como direito básico do consumidor, "a facilitação de seus direitos, inclusive com a inversão do ônus da prova, a seu favor, quando for ele hipossuficiente."

27 MARQUES, Cláudia Lima. Contratos no Código de Defesa do Consumidor, 3 ed., Rev. Atual. e Ampl. São Paulo: RT, 1999, pág.286. 
O consumidor, muitas vezes, não tem condições técnicas necessárias para demonstrar a responsabilidade do fornecedor, pois somente este detém integralmente as informações sobre o produto ou serviço que irá oferecer no mercado de consumo.

Nessa situação, cabe ao magistrado inverter o ônus da prova a favor do consumidor hipossuficiente, cabendo ao fornecedor apresentar provas que demonstrem a inexistência dos fatos constitutivos do direito do consumidor.

\section{f) Princípio do acesso à justiça}

Mostra a necessidade de facilitar o acesso à justiça e efetivar o processo, criando meios de desobstruir o acesso a ele e o tratamento coletivo de pretensões individuais, assim como a possibilidade de inversão do ônus da prova.

Este princípio está explicito em um grande número de dispositivos do CDC que, na busca de dar efetividade ao processo e facilitação do acesso à justiça, exigiu o fortalecimento do consumidor com a criação de mecanismos de ordem processual que realmente representassem a desobstrução do acesso à justiça e o tratamento coletivo de pretensões individuais que, isoladamente, poucas condições teriam de adequada solução. 28

Verifica-se a preocupação do legislador pátrio em criar meios de disponibilizar uma melhor proteção dos direitos do consumidor quando o mesmo se sentir neles lesados.

Desse modo, sempre que o turista/hóspede/consumidor se sentir lesado em relação a eventuais e inadequados serviços turísticos ou de hospitalidade, poderá recorrer ao Judiciário pedindo reparação de danos materiais e morais, se for o caso.

28 FILOMENO, José Geraldo de Brito. Código de defesa do consumidor comentado pelos autores do anteprojeto. 7.ed. Rio de Janeiro: Forense Universitária, 2001, pág.44/45. 


\section{IV - DO CONTRATO DE TURISMO E HOSPITALIDADE}

É muito importante destacar a diferença existente entre um contrato de viagem e um contrato de turismo; a princípio, parecem idênticos, mas o contrato de viagem é mais abrangente, englobando diversos tipos de contratos, como contrato de turismo, contrato de transporte (aéreo, rodoviário, marítimo e ferroviário), contrato de hospedagem, contrato de viagem de negócios e outros, ademais, a expectativa das partes contratantes na relação jurídica é diferente.

\section{CONTRATO DE VIAGEM}

O contrato de viagem indica obrigações, que nem sempre estão relacionadas ao lazer, diferentemente do de turismo.

O exemplo clássico são duas viagens: uma de contrato de viagem de negócios e outra de turismo. Um empresário que viaja para uma convenção em Recife estará celebrando contrato de viagem de negócios, que pode ou não estar sendo protegido pelo Código de Defesa do Consumidor. Uma família que viaja para Recife em férias estará celebrando um contrato de turismo, regido pelo mesmo Código. A diferença de um exemplo para outro é de fácil percepção, pois a expectativa em relação à viagem de negócios é diferente da expectativa em relação à de turismo, sendo que, na primeira, o contratante utiliza-se do contrato como meio, e, na segunda, como finalidade.

Logo, o contrato de viagem é aquele que utiliza qualquer de suas atividades de transporte e hospedagem, para satisfazer a expectativa do contratante como atividade de meio ou como atividade de fim.

\section{CONTRATO DE TURISMO}


O contrato de turismo é aquele que é realizado com o intuito de lazer, ou seja, um prestador de serviço que, sempre evocando a expectativa do consumidor, lhe oferece a oportunidade de diversão em qualquer meio ambiente natural, artificial ou cultural.

Estes contratos são fechados entre agências de turismo e consumidores, incluindo em seu objeto não só a viagem (aérea, marítima ou terrestre), mas também a hospedagem, os translados e uma série de atividades recreativas, com excursões, idas a museus, shows etc. É um contrato de prestação de serviço, mas os serviços nem sempre são prestados pela agência e sim por uma verdadeira rede de fornecedores, ficando a depender destes a qualidade de prestação no total.29

Da forma mencionada, o contrato de turismo é um dos tipos de contrato de viagem, sempre regulado pelo CDC, uma vez que sempre existirão os dois pólos da relação consumerista, com objetivo de uma prestação de serviços.

As partes desse contrato são facilmente identificadas, pois, de um lado, temos um fornecedor ou grupo de fornecedores, liderados por uma agência ou operadora de turismo, e, de outro, um consumidor ou um grupo de consumidores; os primeiros com a vontade de explorar a atividade econômica e os segundos com a vontade de lazer.

Ainda, é necessário distinguir entre o que habitualmente se conceitua como operadora e o que é, comumente, designada agência de viagem.

A operadora é a empresa responsável pelo planejamento, organização e negociação direta com fornecedores, pelos valores de transporte e hospedagem, a custos inferiores aos do mercado, para a formação do chamado "pacote de turismo”.

Normalmente um pacote turístico, nacional ou internacional, é composto da hospedagem, transporte (aéreo, rodoviário, ferroviário, marítimo, etc.), alimentação, translados ("transfer"), guias locais, etc. Existe o pacote individual (“forfait”), em que o consumidor junto ao agente de viagem escolhe o hotel, a companhia aérea, os locais para os quais pretende viajar, enfim, monta o pacote sob medida. No pacote em grupo, ou seja, a excursão, os horários, meios de transportes, hotéis já estão preestabelecidos, vindo o

29 MARQUES, Cláudia Lima. Contratos nos Códigos de Defesa do Consumidor. $3{ }^{\text {a }}$ ed., São Paulo: Revista dos Tribunais, 1999, pág. 176 
consumidor a se integrar ao oferecido; entretanto, em algumas situações e com pagamento em separado, se quiser, pode pedir mais ingressos de shows, locação de carro, etc. O custo total do pacote é bem inferior ao valor apresentado se o consumidor adquirir a hospedagem e transporte aéreo diretamente.

Já a agência de viagens também pode elaborar os pacotes, mas, normalmente revende pacotes das grandes operadoras, ganhando uma comissão para cada venda realizada. A responsabilidade, de acordo com do CDC, é solidária entre a agência e a operadora.

Podem ser fornecedores em contrato de turismo:

\section{a) Agências de turismo}

São empresas comerciais com a finalidade de realizar viagens. Por conseguinte, são prestadoras de serviços, que informam, organizam e tomam todas as medidas necessárias, em nome de uma ou mais pessoas que desejam viajar. Oferecem todas as prestações de serviços relativas a transporte, hotelaria e manifestações turísticas de todos os tipos, e organizam viagens individuais ou coletivas a um preço determinado, seja através de programas estabelecidos por elas mesmas, seja pela livre escolha dos clientes.30

As agências de turismo dividem-se em dois grupos: agências de viagens e turismo e agências de viagens:

"As agências de viagens e turismo correspondem ao conceito de "operadoras turísticas", conhecidas internacionalmente como tour operators. A operadora, ao elaborar o pacote turístico, efetua contratos com hotéis, transportadoras e outras empresas, assumindo o risco de preencher ou não as vagas solicitadas. Em vez do hotel ou da transportadora suportar o risco de não vender seus lugares ou apartamentos, é a operadora turística que arca com ele. Isso já não ocorre com as agências de viagens pois, de acordo com o número de pedidos, solicitam reserva de hospedagem e transporte.

(...) A segunda categoria corresponde às agências de viagens, com a função de facilitar e resolver todos os problemas dos turistas a fim de que possam realizar suas viagens de maneira mais satisfatória possível. A agência de viagens, pela sua organização, pessoal especializado e informações disponíveis proporciona ao clientes todos os elementos para realização de viagens seguras e bem organizadas.” 31

30 BENI, Mário Carlos. Análise estrutural do turismo. São Paulo: Senac, 1998. pág. 182.

31 BENI, Mário Carlos. Análise estrutural do turismo. São Paulo: Senac, 1998. pág. 182/183. 


\title{
b) Empresa hoteleira
}

Pertencente à Cadeia de Fornecedores, temos a Empresa Hoteleira, que se situa como prestadora de serviços de acomodação para o consumidor e empresa de venda de produtos para satisfazer as necessidades de consumo do próprio consumidor.

Esse fornecedor é importante na relação de consumo, uma vez que dará guarida ao consumidor no momento do lazer.

“A empresa hoteleira é um dos elementos essenciais da infra-estrutura turística, constituí um dos suportes básicos para o desenvolvimento do Turismo num País. ”32

\section{c) Timeshare}

Outro fornecedor, em potencial, em nossa relação de turismo consumerista, é o que se apresenta, no que é chamado timeshare ou espaço compartilhado, em que o consumidor adquire direitos por determinado tempo de acomodação em um condomínio de multiproprietários.

\begin{abstract}
Contrato de múltiplas características geralmente visa ao uso de um imóvel em área turística por determinado tempo por ano (1 ou 2 semanas ou meses). $O$ sucesso da fórmula deve-se ao seu pragmatismo e e flexibilidade: resolve a crise do setor hoteleiro e turístico imobiliário, ao assegurar-lhe consumidores cativos, mas exige pequeno investimento dos clientes, ávidos de alcançar o tão esperado lazer e descanso em áreas turísticas valorizadas. Por pequena soma de dinheiro, alcançam o consumidor e sua família a fruição de um espaço, um imóvel e localidade turística procurada, sem que tenham de suportar os custos normais de um imóvel próprio (manutenção contínua, impostos etc.), combinados com vantagens organizacionais: possibilidade de locar para outros a "sua semana de férias" ou mesmo, em caso de não usufruir no seu tempo e lugar determinado, de trocar os seus "direitos habitacionais de uso: de forma a usufruir férias em outro lugar no mundo, através de bolsa internacional de trocas. $\mathbf{3 3}$
\end{abstract}

32 BENI, Mário Carlos. Análise estrutural do turismo. São Paulo: Senac, 1998. pág. 187.

33 MARQUES, Cláudia Lima. Contratos nos Códigos de Defesa do Consumidor. $3^{a}$ ed., São Paulo: Revista dos Tribunais, 1999, pág. 178. 


\section{d) Empresas de Transporte}

O transporte é parte fundamental no contrato de turismo, pois é responsável pelo deslocamento de pessoas para áreas que pretendem alcançar. Nesse mesmo sentido, Beni (1998, pág.192) posicionou-se:“O deslocamento pode ser feito através de diversos meios de transporte de acordo com a preferência do turista, condicionada geralmente ao custo e ao destino e viagem.” 34

O transporte pode ser realizado de diferentes maneiras e formatações, classificandose como: ferroviário (trem), marítimo, fluvial e lacustre (desde embarcações simples e pequenas até luxuosos navios com verdadeiros complexos de acomodação e lazer), rodoviário (ônibus e automóveis) e aéreo.

No contrato de turismo outro fator significativo é a importância do marketing, realizado através de uma oferta chamativa e uma publicidade envolvente, como ponto de atração para os consumidores, sendo necessário para o primeiro contato entre o fornecedor e os consumidores.

O contrato de turismo não caracterizado pela formalidade muitas vezes é feito verbalmente, isto é, o consumidor aprecia folhetos publicitários do local e contrata com o fornecedor.

O contrato de turismo, também denominado “pacote turístico”, vem sendo bastante difundido e utilizado pela moderna sociedade de consumo. Deve trazer todas as informações necessárias para os consumidores, como a descrição do local, hotel, meio de transporte, bem como a informação da quantidade e quem são os fornecedores que realizarão para o consumidor o serviço de turismo.

O consumidor deve ser informado, ainda, das situações climáticas do local onde se estabelecerá a execução do contrato de turismo, pois, muitas vezes, são apresentadas determinadas fotos de locais com alguma atração que depende exclusivamente do clima.

34 BENI, Mário Carlos. Análise estrutural do turismo. São Paulo: Senac, 1998. pág. 192. 
Aliás, o contrato de turismo deveria iniciar com a declaração de qual é a expectativa do consumidor com o serviço ofertado, assim seria possível ao fornecedor paralisar uma contratação por não poder atender aos anseios de seu cliente, ou, então, dar a oportunidade ao cliente de reformar suas expectativas antes da contratação, adaptando-se às condições expostas previamente pelo fornecedor.

\section{CONTRATO DE HOSPEDAGEM}

Conforme já citado, os meios de hospedagem são um dos principais fornecedores das empresas de turismo, destacando-se a empresa hoteleira, uma das mais utilizadas pelo consumidor.

É o vínculo existente entre o hospedeiro e o indivíduo, com a finalidade de acolhimento, com ou sem fins lucrativos e independentemente de formação profissional.

A hospedagem, independentemente de contrato, ou seja, tácita, gera obrigações e direitos. Obrigação do hoteleiro em zelar pelo bem-estar de seu hóspede e daquele de pagar o preço, caso a hospedagem seja remunerada.

\section{a) Hospedagem remunerada}

A hospedagem remunerada, ou a título oneroso e comutativo, constitui espécie de contrato inominado, ou atípico, o qual, conforme a doutrina de Messíneo, se subordina às normas gerais dos contratos $e$, ainda, às leis de ordem pública pertinente à matéria, incidindo em relação à mesma diferentes disposições de direito o que acontece, à mor das vezes, em hotéis, pensões, casas fornecedoras de pousadas, etc. 35

\section{b) Hospedagem profissional}

Refere-se àquelas pessoas, naturais ou jurídicas, que contratam a hospedagem de forma profissional, que se organizam para explorar o serviço de dar hospedagem, estando submetida a 
um conjunto de previsões jurídicas (comerciais, civis e nestas, as normas especiais do Direito das Relações de Consumo) próprias. 36

Não só os hotéis desempenham profissionalmente atividades de hospedagem, mas também todos os considerados meios de hospedagem: pousadas, estalagens, casas de pensão, albergues, etc. Em tais circunstâncias, não se trata apenas de dar abrigo ao hóspede, mas da disponibilidade de serviços e produtos de hospedagem (como alimentos e bebidas, etc), que exige que o ambiente de acolhida seja adequado para o pernoite pelo período contratado, que haja segurança, higiene, qualidade, etc., principalmente diante das garantias dispostas na Lei 8.078/90, que criou o Código de Defesa do Consumidor .

Regras gerais para qualquer tipo de contrato:

O Código de Defesa do Consumidor garante o equilíbrio dos direitos e obrigações na assinatura de qualquer tipo de contrato. Assim, não são permitidas cláusulas que:

- diminuam a responsabilidade do fornecedor no caso de dano ao consumidor;

- proíbam o consumidor de devolver o produto ou reaver a quantia já paga quando o produto ou serviço apresentar defeito;

- $\quad$ estabeleçam obrigações para outras pessoas além do fornecedor e do consumidor;

- coloquem o consumidor em desvantagem exagerada;

- estabeleçam obrigatoriedade somente para o consumidor apresentar provas no processo judicial;

- proíbam o consumidor de recorrer diretamente a um órgão de proteção ao consumidor ou à justiça, sem antes recorrer ao próprio fornecedor ou a quem ele determinar;

- possibilitem ao fornecedor modificar qualquer parte do contrato, sem autorização do consumidor;

- estabeleçam perda das prestações já pagas por descumprimento de obrigações do consumidor.

35 GUSMÃO, Sady Cardoso, citado por MAMEDE, Gladston. Manual de direito para a administração hoteleira. São Paulo: Atlas, 2002, pág. 144)

36 MAMEDE, Gladston. Manual de direito para a administração hoteleira. São Paulo: Atlas, 2002, p. 148. 


\section{A EXPECTATIVA DO CONSUMIDOR}

O turismo é um elaborado e complexo processo de decisão sobre o que visitar, onde, como e a que preço. Nesse processo intervêm inúmeros fatores de realização pessoal e social, de natureza motivacional, econômica, cultural, ecológica e científica que ditam a escolha dos destinos, a permanência, os meios de transportes e os meios de hospedagem, bem como o objetivo da viagem em si para a fruição tanto material como subjetiva dos conteúdos de sonhos, desejos, expectativas, de imaginação projetiva, de enriquecimento existencial histórico-humanístico, profissional, etc.

No turismo e hospitalidade, assim como em qualquer contratação consumerista, um dado importante é a expectativa do hóspede/consumidor, isto é, o que ele espera do serviço contratado. A expectativa do consumidor moderno é imprevisível e não tem limite. Quanto mais recebe, mais exige. Mas é possível ficar atento ao que é básico e esperado. Em cada segmento, na indústria de bens de consumo ou serviços, existem condutas e ações que se poderiam classificar como óbvias, claramente determinantes do sucesso ou do fracasso na satisfação de expectativas. Essa questão é importante, pois, satisfeita sua expectativa, o hóspede não se queixará da contratação. Imagine um hotel planejado para eventos no qual a internet e o serviço de recados não funcionam; ou no caso do hóspede consumidor que contrata um hotel de categoria cinco estrelas, próximo da praia e com vista para o mar e, chegando ao destino, é acomodado em hotel de categoria inferior, longe da praia e com vista para um cemitério ou para um depósito de lixo.

A expectativa do consumo é garantida no Código de Defesa do Consumidor, uma vez que ele protege a boa-fé como princípio, ou seja, obriga o contrato a trazer informações claras, proibindo a publicidade enganosa e abusiva, protegendo-se de práticas comerciais nefastas.

O consumidor do turismo tem como expectativa à diversão, logo, nada poderá afetar o seu humor, ou seja, se ele contrata um meio de hospedagem que oferece uma piscina fantástica, não pode o hóspede/consumidor encontrá-la fechada para reformas sem que antes isso tivesse sido informado, ferindo sua expectativa. 
As expectativas legítimas são, igualmente, o conjunto de circunstâncias cuja existência ou permanência é objetivamente típica ou necessária para aquele tipo de contrato em especial possa se constituir em uma regulamentação sensata, com razoável distribuição de riscos. Este conjunto de motivações, de causas iniciais que representam as finalidades do negócio admitidas bilateralmente ou típicas daquela relação são a base mínima (objetiva) da relação, do contrato de consumo. Excluídas aquelas circunstâncias que fazem parte dos riscos contratuais típicos, excluídas as expectativas legítimas, que também são denominadas de "causas" ou fontes da confiança despertada no parceiro contratual mais fraco e devedor (vetrauensmstände), o desequilíbrio da relação é flagrante. Estas expectativas legítimas são, portanto consideradas, especialmente na doutrina alemã, como juridicamente relevantes e protegidas pela cláusula geral do § 242 do BGB sobre a boa-fé e das necessidades do tráfico jurídico na sociedade atual. Em outras palavras, são estas expectativas legítimas que formam a "base" do negócio (Geschäftsgrundlage), e será a quebra objetiva da base do negócio (Eegfall der Geschäftsgrundlage) motivo para a revisão do conteúdo dos contratos, sempre na tentativa de manutenção do vínculo e de adaptação da relação razoável e suportável por ambos os contratantes. 37

No que tange à expectativa no contrato de turismo e hospedagem, é fácil afirmar que seu não cumprimento fere toda a contratação, pois, se o objetivo é o lazer, por exemplo, a quebra de expectativa gera problemas, desconfortos, aborrecimentos, tristeza; portanto, no lugar de diversão, o hóspede/consumidor experimentará a violação de seus direitos. O correto ao se realizar a expectativa é simplesmente cumprir o informado, ou, até mesmo, superar aquilo que lhe foi prometido no contrato.

Configurada a insatisfação da expectativa do consumidor, ela ocasiona danos materiais e morais, gerados pela frustração da contratação.

Não se pode considerar que o extravio ou desaparecimento de uma mala, por exemplo, cause apenas dano material, pois causa também dano moral. No contrato de turismo, encontrar em um quarto de hotel lençóis sujos e acomodação insatisfatória, diferentemente do prometido, gera também dano moral.

Logo, a expectativa para o contrato de turismo e hospitalidade é fator predominante e parte integrante do próprio negócio a ser realizado, considerando-se que a sua quebra possa gerar como conseqüências a revisão contratual, rescisão contratual e indenização por danos material e moral.

É valido ressaltar que a expectativa aqui comentada é gerada pela boa-fé na contratação e não privilegia consumidores de má-fé.

\section{A OFERTA NO CONTRATO DE TURISMO E HOSPITALIDADE}

37 MARQUES, Cláudia Lima. Contratos, nos Códigos de Defesa do Consumidor. 3 ed. São Paulo: Revista dos Tribunais, 1999. 
A oferta dos serviços de turismo e hospitalidade é fundamental, pois muitos dos contratos são celebrados de forma verbal, tomando consumidor conhecimento do serviço através de anúncios ou fotos divulgadas em panfletos, folders, revistas ou jornais e, até mesmo, através da rede mundial de informação (internet).

As promessas feitas pelos meios de hospedagem ao mercado, veiculadas por qualquer mídia, devem expressar com fidelidade as condições do empreendimento, incluindo os aspectos relativo às instalações, sua localização e características (geográficas, humanas, culturais, turísticas) da região em que foi construído, a qualidade dos serviços que são prestados. Interessados pela oferta devem encontrar facilidade em consultar preço total dos serviços, o que inclui informações sobre o que está e o que não está incluído, condições de pagamento e, eventualmente, de financiamento. Todas essas informações constituem promessa (compromisso) de fazer e fornecer da qual não pode esquivar-se o empreendimento, caso alguém queira aderir ao contrato proposto 38.

O Código de Defesa do Consumidor, por sua vez, não proíbe a oferta, apenas a regulamenta para equilibrar o mercado, Vejamos:

“Artigo 30. Toda informação ou publicidade, suficientemente precisa, veiculada por qualquer forma ou meio de comunicação com relação a produtos e serviços oferecidos ou apresentados, obriga o fornecedor que a fizer veicular ou dela se utilizar e integra o contrato que vier ser celebrado.

Artigo 31. A oferta e apresentação de produtos ou serviços devem assegurar informações corretas, claras, precisas, ostensivas e em língua portuguesa sobre suas características, qualidades, quantidade, composição, preço, garantia, prazos de validade e origem, entre outros dados, bem como sobre riscos que apresentam à saúde e segurança de consumidores.”

Se o fornecedor recusar-se a cumprir o que veiculou na oferta, apresentação ou publicidade, o consumidor poderá, alternativamente e a sua livre escolha (Artigo 35):

I - exigir o cumprimento forçado da obrigação, nos termos da oferta, apresentação ou publicidade;

II - aceitar outro produto ou prestação de serviços equivalentes;

III - rescindir o contrato, com direito à restituição de quantia eventualmente antecipada, monetariamente atualizada, e a perdas e danos. INCLUI-SE AQUI O DANO MORAL.

38 MAMEDE, Gladston. Manual de direito para a administração hoteleira. São Paulo: Atlas, 2002, pág. 113. 
Ademais, em toda e qualquer divulgação (anúncio, propaganda, etc.) de empreendimento hoteleiro cadastrado na EMBRATUR, deverá constar a sigla desta, em caixa alta e por extenso, e seu número de registro, em tamanho que permita sua fácil leitura, o que permitirá informar o usuário da habilitação legal da empresa para a prestação de serviços divulgados, distinguindo a divulgação efetuada por empresas registradas das feitas por terceiros não capacitados, e de que a qualidade do produto está sujeita ao controle da EMBRATUR. Não se admite a inserção, nos anúncios, de abreviações da sigla EMBRATUR, ou de quaisquer outras abreviações que não sejam do conhecimento geral.

Na relação de consumo, a oferta é parte integrante do contrato, seja ele verbal, escrito, por adesão, sendo nula qualquer disposição em contrário que desobrigue o fornecedor daquilo que prometeu.

Ao aplicarmos o Código de Defesa do Consumidor no turismo e hospitalidade , e sabedores de que estamos diante de um sistema em que o marketing tem papel fundamental, impõe-se que todos os seus meios de divulgação sejam cumpridos na sua execução.

É comum verificar em ofertas de turismo a presença da palavra “similar”, ou seja, apresenta-se um hotel e na informação do pacote turístico vem o nome do hotel ou similar.

A presente informação não é correta. O fornecedor deve comunicar ao consumidor todos possíveis hotéis que se enquadram nessa modalidade apresentada como similar, a fim de não levar o hóspede/consumidor a erro de interpretação.

Dessa maneira, o marketing de turismo e hospitalidade tem que respeitar as regras de equilíbrio determinadas pelo Código de Defesa do Consumidor, não podendo, de qualquer forma, enganar o consumidor, conduzir a erro, ou omitir informações necessárias para convicção da expectativa.

Reportando-nos ao Artigo 31 do Código de Defesa do Consumidor, podemos constatar que o rol nele apresentado não é taxativo, e sim exemplificativo. Logo, no contrato de turismo e hospitalidade a informação climática é necessária, pois os 
fornecedores dividem o serviço devido, baseando-se em aspectos referentes a clima, festas, férias escolares e outros, em baixa temporada/estação e alta temporada/estação.

A baixa temporada/estação compreende valores menores pelo mesmo serviço prestado na alta estação. Parece uma regra básica de mercado: quanto maior a oferta, menor o preço; quanto maior a procura, maior o preço.

Um consumidor de baixa temporada, por exemplo, deve ser informado sobre a quais atrativos turísticos ele não terá acesso, em virtude de fatores climáticos.

Outro item importante, a ser acrescido como informação necessária, é aquele que se refere ao serviço do meio de hospedagem, como, por exemplo, reformas em suas acomodações, pois o hóspede/consumidor deve receber informação adequada sobre tudo que poderá prejudicar o seu lazer. Essas informações são importantes, porque criam a expectativa do consumidor, pois uma pessoa pode querer viajar para apreciar a neve, e o clima na época não ser propício, diferentemente do que lhe foi sugerido por fotos. Da mesma forma, o turista deseja descanso, busca um hotel para repousar e depara-se com barulho causado por reformas durante sua estada ou algazarra de alunos de escolas na “semana do saco cheio".

Ofertar é assumir compromissos que devem ser cumpridos. A oferta é essencial para a formação da expectativa de consumo, e daí advém todo cuidado a ser tomado com os fatores que se refletirão diretamente na contratação e irão gerar efeitos quanto à responsabilidade por danos principalmente morais.

\section{PUBLICIDADE NO TURISMO E HOSPITALIDADE}

A publicidade, como vulgarmente se diz na nossa sociedade massificada, "é a alma do negócio”, e isso significa dizer que seria impossível existir relação de consumo sem a existência de publicidade. 
A nossa Constituição permite a publicidade, que pode revelar o que desejar, desde que respeitados os balizamentos expostos no próprio texto constitucional.

O Código de Defesa do Consumidor regulamenta e permite a publicidade, mas coíbe a enganosa e a abusiva, assim definindo-as:

“Artigo 36. A publicidade deve ser veiculada de tal forma que o consumidor, fácil e imediatamente, a identifique como tal.

Parágrafo único. O fornecedor, na publicidade de seus produtos ou serviços, manterá em seu poder, para informação dos legítimos interessados, os dados fáticos, técnicos e científicos que dão sustentação à mensagem.

Artigo 37. É proibida toda publicidade enganosa ou abusiva.

$\S 1^{\circ}$. É enganosa qualquer modalidade de informação ou comunicação de caráter publicitário, inteira ou parcialmente falsa, ou, por qualquer outro modo, mesmo por omissão, capaz de induzir $m$ erro o consumidor a respeito da natureza, características, qualidade, quantidade, propriedades, origem, preço e quaisquer outros dados sobre produtos e serviços.

$\S 2^{\circ}$. É abusiva, dentre outras, a publicidade discriminatória de qualquer natureza, a que incite a violência, explore o medo ou a superstição, se aproveite da deficiência de julgamento e experiência da criança, desrespeita valores ambientais, ou que seja capaz de introduzir o consumidor a se comportar de forma prejudicial ou perigosa à sua saúde ou segurança.

$\S 3^{\circ}$. Para os efeitos desse Código, a publicidade é enganosa por omissão quando deixar de informar sobre dado essencial do produto ou serviço."

Como decorrência de sua importância no mercado, surge a necessidade de que o fenômeno publicitário seja regrado pelo Direito, notadamente pela perspectiva da proteção do consumidor, o ente vulnerável da relação jurídica de consumo.”

O controle da publicidade, prejudicial ao consumidor, não pode ser considerado como uma censura à liberdade de criação, pois apenas protege a sociedade de mensagens que podem gerar enganos, prejudiquem a saúde e desrespeitem os seus valores morais, culturais e sociais.

A publicidade, não só a decorrente da relação de consumo, passou a ser regulamentada pelo Código Brasileiro de Auto-Regulamentação Publicitária, que é um 
acordo de regras éticas para o setor publicitário, criado por entidades representativas do mercado de publicidade.

O Código de Auto-Regulamentação Publicitária - CBAP - manifestou-se em relação ao Turismo:

A propaganda de turismo, viagens, excursões e hotelaria deverá ser concebida de forma que se evitem desapontamentos para o consumidor. Portanto no caso particular de excursões, o material publicitário - sejam anúncios, sejam folhetos e prospectos - deve fornecer dados precisos no tocante aos seguintes aspectos:

a) firma ou organização responsável pela excursão;

b) o meio de transporte, nome da empresa transportadora, tipo ou classe do avião, dados sobre o navio ou outro meio de transporte;

c) destinos e itinerários;

d) a duração da excursão o tempo de permanência em cada localidade;

e) o tipo de padrão das acomodações de hotel e as refeições porventura incluídas no preço pacote;

f) quaisquer benefícios incluídos, tais como passeios, ingressos de museus etc.;

g) o preço total da excursão - pelo menos em seus limites máximo e mínimo - , com indicação do que está ou não incluído (traslados de e para aeroportos e hotéis, carregadores, gorjetas etc.);

h) condições de cancelamento."

À lista supra, acrescentaríamos alguns itens, que já discorremos a respeito, quais sejam:

a) nome de todos os prestadores de serviços ligados diretamente nos serviços executados;

b) lista de similares para cada serviço do Turismo;

c) informação de que a prestação de serviço de Turismo será realizada na alta ou baixa estação;

d) informação quanto ao clima naquela oportunidade;

e) se algum atrativo derivados dos meios ambientes artificial, natural e cultural não estiver disponível para aquele evento. 39

No que tange às regras claras do Código de Defesa do Consumidor, a publicidade turística não pode ser enganosa, isto é, não pode conduzir o consumidor a erro ou fazê-lo acreditar em alguma coisa que não corresponda à realidade do produto ou ao serviço em si (é enganosa qualquer modalidade de informação ou comunicação de caráter publicitário, inteira ou parcialmente falsa, capaz de induzir em erro o consumidor a respeito da natureza, das características, da qualidade, da quantidade, das propriedades, da origem, do preço e de quaisquer outros dados a respeito dos produtos e serviços oferecidos).

39 NUNES, Luiz Antonio Rizzato. Comentários ao código de defesa do consumidor. direito Material._São Paulo: Saraiva, 2000. 
O consumidor de turismo/hospitalidade não pode adquirir um pacote de viagem e, ao chegar ao local tratado, encontrar algo completamente diferente do que lhe foi ofertado. $\mathrm{O}$ consumidor foi enganado, evidenciando-se a má-fé do fornecedor, o que para o Código de Defesa do Consumidor é inadmissível.

O Código de Defesa do Consumidor proíbe as propagandas abusivas previstas no $\S 2^{\circ}$ do Artigo 37, já citado, em que o legislador se preocupou, entre outras coisas, com a vida, a saúde do consumidor, bem como com a proteção ambiental, isto é, com os meios ambientes natural, artificial e cultural, que a publicidade abusiva possa lesar ( é abusiva, entre outras, a publicidade discriminatória de qualquer natureza, a que incite à violência, explore o medo ou a superstição, se aproveite da deficiência de julgamento e experiência da criança, desrespeite valores ambientais, ou que seja capaz de induzir o consumidor a se comparar de forma prejudicial ou perigosa a sua saúde ou segurança.)

O caráter da abusividade não tem necessariamente relação direta com o produto ou serviço oferecido, mas sim com os efeitos da propaganda que possam causar algum mal ou constrangimento ao consumidor.

No turismo e hospitalidade, a proteção do Código de Defesa do Consumidor veio corroborar com o que pretendem os profissionais sérios do ramo, observando-se que para estes não interessa o consumidor sentir-se lesado em face do informe publicitário, pois, tal ocorrência acabaria poluindo o próprio sistema de turismo e os empreendimentos hoteleiros.

A proibição de publicidade entendida como abusiva, no turismo, também tem reflexo na proteção ambiental, nos efeitos que a mesma pode gerar, nas suas conseqüências, inclusive com mudanças de caráter cultural.

Poderíamos dizer que o $\S 3^{\circ}$ do Artigo 37 do Código de Defesa do Consumidor é o que mais protege o consumidor no sistema de turismo por tratar de publicidade enganosa por omissão. 
A omissão, sem dúvida, é o que mais se pratica nas más empresas do setor, pois deixam de informar ao seu cliente condições necessárias ou essenciais para que ele preencha suas expectativas.

\begin{abstract}
"A publicidade pode ser enganosa tanto no que diz como pelo que não diz. Enquanto na publicidade enganosa comissiva qualquer dado do produto ou serviço presta-se para induzir o consumidor a um erro, na publicidade enganosa por omissão só a ausência de dados essenciais é reprimida." 40
\end{abstract}

Logo, é comum o fornecedor não informar alguma característica essencial do serviço turístico, levando o consumidor a adquirir e, pior, a sonhar com aquilo que não existe.

Notadamente, quando se engana comissiva ou omissivamente, além de se enganar o consumidor materialmente, atinge-se sua expectativa, formada através da oferta, causandolhe aborrecimentos e trazendo danos de ordem moral.

Suponhamos uma família, em que o marido e a esposa trabalhem e possuam filhos menores e devidamente matriculados em escola pública, que programe uma viagem de férias com destino a um resort. Ao chegar ao local, percebem que não foram informados, pelo anúncio publicitário, de que o parque aquático estava em reforma. Além do dano material suportado, há a frustração do pai e da mãe em não poderem oferecer diversão aos filhos, e há a frustração dos filhos por não usufruírem do parque e das piscinas. Logo, além do dano material, há o dano moral, pois ocorreu aborrecimento familiar causado pelos transtornos.

Nessa linha de raciocínio, enganar em turismo não se limita apenas em não prestar o serviço, é, também, destruir um sonho.

É muito comum, ainda sobre esse aspecto de anúncios publicitários, ter diversos fornecedores, principalmente aqueles de grande porte, que trazem tranqüilidade ao consumidor na contratação.

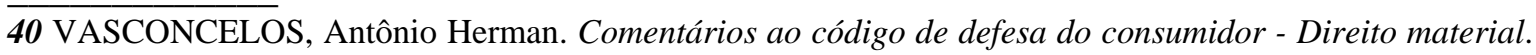
São Paulo: Saraiva, 2000. 
Podemos afirmar que no texto publicitário a figura do aconselhamento traz tranqüilidade ao consumidor, uma vez que tenta lhe transmitir a garantia de que ele está diante de um serviço confiável, ou seja, uma grande empresa no rol de fornecedores induz o consumidor à contratação, devendo, se necessário, ser responsabilizada pela prestação de serviços inadequados no pacote turístico. É o caso, por exemplo, da TAM VIAGENS, que oferece pacotes ou viagens com estada nos melhores hotéis e resorts do Brasil, utilizandose do nome e da credibilidade da empresa de transporte aéreo TAM . Nesse caso, todos os anunciantes são responsáveis diretos pela total execução do serviço de turismo. 
V - DA RESPONSABILIDADE NO CONTRATO DE TURISMO E HOSPITALIDADE EM FACE DO CÓDIGO DE DEFESA DO CONSUMIDOR

\section{1 . RESPONSABILIDADE OBJETIVA NO CDC}

O Código de Defesa de Consumidor cuidou na seção II, do capítulo VI da responsabilidade pelo fato do produto ou serviço, consagrando a responsabilidade objetiva (Artigos 12 e 14), abolindo qualquer referência à responsabilidade contratual ou extracontratual.

Antes da vigência do Código de Defesa do Consumidor, a base legal da responsabilidade civil estava regulamentada pelo então Artigo 159 do Código Civil, que a denominava como subjetiva, isto é, para que se tivesse direito à reparação (indenização), em função de dano causado, era necessário provar a conduta culposa (negligência, imprudência ou imperícia) do agente.

Entretanto, a sociedade de consumo, com seus diversos produtos e serviços oferecidos ao consumidor, não poderia ser submetida à responsabilidade civil baseada em culpa.

Se o CDC determina nos direitos básicos do consumidor, Artigo $6^{\circ}$, VI, a "efetiva prevenção e reparação dos danos”, subentende a responsabilidade objetiva, uma vez que não há qualquer menção à conduta do agente. Portanto, caso a lei não preveja que, para a reparação de danos, o causador deva agir (=conduta) com negligência, imprudência, imperícia ou dolo, a responsabilidade será denominada objetiva.

"O que caracteriza a responsabilidade objetiva é a norma indicar a responsabilidade de alguém, sem mencionar ou exigir determinada conduta. Irrelevante, portanto, a expressão independente de culpa para configurar a responsabilidade objetiva." 41

41 (Nery Junior. Nelson; Andrade Nery, Rosa. Código de Processo Civil e Legislação processual civil extravagante em vigor, p. 988) 
Como pressupostos dessa responsabilidade são enumerados:

- a colocação do produto ou serviço no mercado de consumo;

- a relação de casualidade entre a ação do fornecedor e o dano verificável;

- dano ressarcível (tanto material quanto moral).

Nessa espécie de responsabilização o fornecedor deve responder pelo prejuízo experimentado pelo consumidor por produto ou serviço defeituoso ou pela utilização de produto por deficiência de informação, quanto ao seu uso ou quanto aos riscos que tal uso poderia ocasionar, independente de ter o consumidor de demonstrar essa culpa, não se levando em conta também o comportamento do sujeito responsável. Para se responsabilizar é necessário somente o confronto da situação jurídica do causador do dano com os fatos relacionados ao consumidor lesado.

Sendo assim, a responsabilização do fornecedor deve ser encarada como um sistema de prevenção e reparação de danos acidentais inevitáveis, em que a avaliação da conduta de uma das partes (o fornecedor) conta pouco ou simplesmente não conta. 42

Portanto, a responsabilidade será sempre objetiva na relação de consumo. Não cabe ao consumidor provar a culpa do fornecedor, mas sim o dano e o nexo de causalidade entre ele e o produto ou serviço consumido.

\section{RESPONSABILIDADE PELO FATO DO SERVIÇO}

O Código de Defesa do Consumidor apresenta como primeira forma de responsabilidade a decorrente pelo fato do serviço.

Artigo 14: O fornecedor de serviços responde, independentemente da existência de culpa, pela reparação de danos causados aos consumidores por defeitos relativos à prestação dos serviços, bem como por informações insuficientes ou inadequadas sobre sua fruição e riscos.

42 STOCO, Rui. Responsabilidade Civil e sua Interpretação Jurisprudencial. 2 ed. São Paulo: Revista do Tribunais, 1995, pág. 149) 
Parágrafo $1^{\circ}$ - O serviço é defeituoso quando não fornece a segurança que o consumidor dele pode esperar, levando-se em consideração as circunstâncias relevantes, entre as quais:

I- o modo de seu fornecimento;

II - o resultado e os riscos que razoavelmente dele se esperam;

III - a época em que foi fornecido. (...)

Nesse artigo, o legislador impõe o termo defeito e se preocupa com a vida digna, segurança e saúde do consumidor impondo, definitivamente, a exclusão da culpabilidade.

Sobre o termo defeito, trazido com o artigo 14:

O defeito é o vício acrescido de um problema extra, alguma coisa extrínseca ao produto. Que causa um dano maior que simplesmente o mau funcionamento, o não funcionamento, a quantidade errada, a perda do valor pago, já que o produto ou serviço não cumprem o fim ao qual se destinam. O defeito causa, além desse dano do vício, outros danos ao patrimônio jurídico material ou moral do consumidor.

Logo, o defeito tem ligação com vício, mas, em termos de dano causado ao consumidor, ele é mais devastador.

Temos, então, que o vício pertence ao próprio produto ou serviço, jamais atingindo o próprio consumidor ou outros bens seus. $O$ defeito vai além do produto ou serviço para atingir o consumidor em seu patrimônio jurídico material e/ou moral. Por isso somente se fala propriamente em acidente de consumo em caso de defeito. É no defeito que o consumidor é atingido. 43

No caso de turismo e hospitalidade, os defeitos previstos no Artigo 14, podem ocorrer desde acidentes no transporte, como, por exemplo, a queda de um avião, a batida de um ônibus de transporte de turismo, a intoxicação alimentar no restaurante do hotel, entre outras.

Nesta hipótese, resta ao consumidor comprovar o nexo de causalidade entre a prestação de serviços turísticos e o dano ocorrido, para que seja detentor da efetiva reparação.

43 NUNES, Luiz Antônio Rizzato. Comentários ao Código de Defesa do Consumidor. São Paulo: Saraiva. 2000, pág. 181. 
Par. $3^{\circ}$ - O fornecedor de serviços só não se responsabiliza quando provar:

I - que, tendo prestado o serviço, o defeito inexiste;

II - a culpa exclusiva do consumidor ou de terceiro;

Assim, para que o turismo ou meio de hospedagem defeituoso se exclua da responsabilidade, somente as hipóteses supra poderão ser elencadas, ou seja, que o serviço não tenha causado malefício ao consumidor, ou se o consumidor foi o agente da culpa, quanto ao terceiro, ele não poderá ser integrante da cadeia de consumo.

\section{RESPONSABILIDADE POR VÍCIO DO SERVIÇO}

O CDC prevê essa responsabilidade quando ocorre vício, isto é, quando a prestação de serviço é inadequada ou insuficiente na sua oferta:

Os vícios, portanto, são os problemas que, por exemplo: ( ...) nos serviços que apresentem características com funcionamento insuficiente e inadequado, como o serviço de desentupimento que no dia seguinte faz com que o banheiro alague; o carpete que descola rapidamente; a parede mal pintada; o extravio de bagagem no transporte aéreo, etc. 44

Prescreve o artigo 20 do CDC:

Artigo 20 - O fornecedor de serviços responde pelos vícios de qualidade que o tornem impróprios ao consumo ou lhes diminuam o valor, assim como por aqueles decorrentes da disparidade com as indicações constantes da oferta ou mensagem publicitária, podendo o consumidor exigir, alternativamente e à sua escolha:

I - a reexecução dos serviços, sem custo adicional e quando cabível;

II - a restituição imediata da quantia paga, monetariamente atualizada, sem prejuízo de eventuais perdas e danos;

44 NUNES, Luiz Antônio Rizzato. Comentários ao Código de Defesa do Consumidor. São Paulo: Saraiva. 2000. pág. 180. 
III - o abatimento proporcional do preço.

Par. $1^{\circ}$ - A reexecução dos serviços poderá ser confiada a terceiros devidamente capacitados, por conta e risco do fornecedor.

Par. $2^{\circ}$ - São impróprios os serviços que se mostrem inadequados para os fins que razoavelmente deles se esperam, bem como aqueles que não atendam as normas regulamentares de prestabilidade.

No turismo, poderíamos facilmente exemplificar, como o sumiço de uma mala em um avião, ônibus, hotel, atrasos em aeroportos, hospedagem em hotéis de categoria inferior à contratada, etc.

O Código, dessa forma, protege os consumidores do mau serviço, sendo que no turismo as situações viciadas ocorrem na má execução do serviço, o que leva o consumidor a pedir abatimento proporcional ou a restituição dos valores pagos e, ainda, a reparação efetiva dos danos.

\section{RESPONSABILIDADE EM FACE DO DESCUMPRIMENTO DA OFERTA}

A responsabilidade do ofertado gera ao consumidor o direito de efetiva reparação, nos termos do artigo 35 do CDC:

Artigo 35 - Se o fornecedor de produtos ou serviços recusar o cumprimento à oferta, apresentação ou publicidade, o consumidor poderá, alternativamente e à sua livre escolha:

I - exigir o cumprimento forçado da obrigação, nos termos da oferta, apresentação ou publicidade;

II - aceitar outro produto ou prestação de serviço equivalente;

III - rescindir o contrato, com direito à restituição de quantia eventualmente antecipada, monetariamente atualizada, e a perdas e danos.

Nessas hipóteses, a responsabilidade do fornecedor advém anteriormente à execução, até mesmo a partir da oferta, podendo o consumidor exigir que o fornecedor cumpra o que publicou. 
Na execução, o consumidor pode aceitar um serviço equivalente ou superior ao contratado se, por exemplo, numa viagem, o consumidor chega a um hotel e não tem todos os atrativos do informe publicitário, o mesmo pode ir para um outro hotel oferecido, ou para um quarto de categoria superior. Mesmo assim, terá direito à rescisão contratual, com a devolução dos valores pagos e, ainda, efetiva reparação de danos.

\section{RESPONSABILIDADE SOLIDÁRIA DOS FORNECEDORES EM ANÚNCIOS PUBLICITÁRIOS DESTINADOS A PACOTES TURÍSTICOS}

O Código de Defesa do Consumidor, no Parágrafo único do Artigo $7^{\circ}$, prevê a solidariedade na cadeia de consumo:

Artigo $7^{\circ}$ (...)

Parágrafo único. Tendo mais de um autor a ofensa, todos responderão solidariamente pela reparação dos dados previstos nas normas de consumo.

Claro que para o turismo importa que todos os fornecedores que estão na cadeia de consumo respondam para o consumidor, principalmente quando se trata do "pacote turístico" que reúne diversos prestadores de serviços, organizado por uma agência de turismo e comercializado junto a consumidores por uma agência de viagens.

O objeto dessa prestação de serviço, além de envolver a viagem propriamente dita, inclui também os serviços anexos, tais como hospedagem, alimentação, translados, excursões a locais típicos, feiras, shows, etc. De um lado, temos diversos prestadores de serviços, mas o consumidor não tem essa visão múltipla, ou seja, trata-se, para ele, de um único serviço que irá realizar seu sonho, seu lazer ou sua diversão.

Assim, o serviço adquirido pelo consumidor não estará vinculado a cada fornecedor, mas será “global”, ou seja, incluirá uma cadeia de fornecedores co-responsáveis entre si.

Observe que a referida cadeia de fornecedores formada exercerá a função de prepostos da contratante e responsáveis em executar os serviços ofertados, podendo o consumidor exigir da agência ou operadora a qualidade e adequação da prestação de todos 
os serviços prometidos e contratados, ainda que a falta ou serviço defeituoso provenha do hotel conveniado, amparado no que dispõe o Código de Defesa do Consumidor, em seu Artigo 34. "O fornecedor do produto ou serviços é solidariamente responsável pelos atos de seus prepostos ou representantes autônomos."

Ressalte-se que um dos pilares do CDC é a responsabilidade objetiva dos fornecedores, portanto, a responsabilidade deve atingir todos os serviços do pacote, incluindo os fornecedores, responsáveis solidários por todos os serviços do pacote turístico, já que, para o consumidor, as diversas prestações desse serviço são apenas uma única prestação de turismo, com a finalidade de realizar sua diversão. Assim, não há motivos legais justificáveis que possam isentar ou diminuir a responsabilidade de qualquer dos fornecedores que compõem a cadeia de responsabilidade que propiciou a colocação do produto no mercado.

Como a responsabilidade é objetiva, decorrente da simples colocação no mercado de determinado produto ou prestação de dado serviço, ao consumidor é conferido o direito de intentar as medidas contra todos os que estiverem na cadeia de responsabilidade que propiciou a colocação do mesmo produto no mercado ou então a prestação do serviço. 45

Cumpre à empresa que vende pacote turístico o risco pela eleição $e$ pela qualidade do estabelecimento prestador dos serviços de hospedagem, até porque o risco da atividade econômica é do fornecedor, e não do consumidor. Quem goza as vantagens também deve suportar as desvantagens. É princípio geral de direito: Qui habet comoda, ferre debet onera. 46

EMENTA: PACOTE TURÍSTICO - VENDA POR AGÊNCIA DE TURISMO - EXECUÇÃO DOS SERVIÇOS POR OUTRA EMPRESA DANOS - RESPONSABILIDADE SOLIDÁRIA.

De acordo com as normas do Código de Defesa do Consumidor, existe a solidariedade passiva de todos os que, de alguma forma, participam da cadeia econômica de produção, circulação e distribuição de produtos ou prestação de serviços. A agencia de turismo responsável pela venda do pacote turístico responde pelos danos decorrentes da má qualidade dos serviços, ainda que estes tenham sido prestados por outra empresa, já que em ambas prevalece a responsabilidade solidária. 47

45 Ada Pellegrini Grinover, citada por Antônio Carlos A de Carvalho. Em artigo Agencias de turismo respondem por serviços do hotel . Publicada na Revista Consultor Jurídico, 03 de novembro de 1999. Disponível em http://conjur.uol.com.br/textos/1936 acesso em nov/2003. 
A empresa que se encarrega da venda do pacote turístico e o divulga é a parte legítima na ação de reparação de dano, quando a avença não foi cumprida integralmente pela empresa que executou os serviços. Existe solidariedade entre elas, que decorre do Código de Defesa do Consumidor - Artigos $7^{\circ}$ e 25, Parágrafo $1^{\circ}$, ambos devendo responder civilmente, inclusive por dispositivo citado no Código Civil, Artigo 186. Uma empresa atua em função de outra.

Ementa: Indenização - Prestação de Serviço - Pacote Turístico Solidariedade Passiva de Empresas por um mesmo interesse - Fato de Terceiro - Culpa Exclusiva - Quebra do Dever de Informação Obrigação de Indenizar.

Tem a agência de viagem, perante seu cliente, consumidor, legitimidade passiva para a ação de reparação por prestação de serviço inadequado, em razão de se tornar responsável pela atuação de toda uma cadeia de fornecedores por ele escolhidos e previamente contratados, resguardando-se eventual regresso desta contra outrem, como a operadora de viagem a quem imputa o adimplemento ruim. Impõe o Código de Defesa do Consumidor, no inciso II do Parágrafo $3^{\circ}$ do Artigo 14, para que haja exclusão do dever de indenizar dos fornecedores, que seja a culpa do terceiro, a quem imputam a responsabilidade pelo dano, "exclusiva", o que não se pode vislumbrar quando ocorre quebra do dever de informação pela parte acionada com que contratou o consumidor diretamente. 48

\section{RESPONSABILIDADE POR DANOS MORAIS}

O Código de Defesa do Consumidor faz previsão à efetiva reparação de danos morais que possam os consumidores ter sofrido na relação de consumo, além da responsabilidade material. O inciso VI do Artigo $6^{\circ}$ considera direito básico do consumidor "a efetiva prevenção e reparação de danos patrimoniais e morais, individuais, coletivos e difusos.”

O dano moral é aquele suportado pela pessoa, quando à mesma é imposta a dor, a vergonha, a humilhação, o aborrecimento, o abalo de sua honra, agressão a princípios pessoais, ou seja, tudo aquilo que estaria extra ao dano moral e que não tem valor certo e determinado.

Na atividade turística, trazida para a esfera da relação de consumo, não se pode descaracterizar o seu acontecimento, isto é, quando um serviço turístico agride a expectativa do consumidor, ou ocorre um acidente de consumo, já se teve a incidência de dano moral. 
No contrato de turismo, quando o serviço não for prestado adequadamente, ocorre o dano moral, pois ele tem como maior objetivo o lazer e a diversão, e quando o serviço não sai a contento, não existe a diversão e nem tampouco o lazer, e essa lesão ao direito do consumidor há de ser indenizada.

EMENTA: INDENIZAÇÃO - VIAGEM TURISMO - NÃO REALIZAÇÃO - DANO MORAL. A agência de turismo e a pessoa física intermediadora da venda da excursão de lazer, na qualidade de agenciadora, respondem pelas conseqüências da não realização da viagem, em decorrência de terem descumprido os termos de contrato. É devida a reparação pelo dano moral pela não consecução da viagem de turismo. A frustração experimentada por aqueles que programaram suas férias, vindo posteriormente a perdê-las, deixando de vivenciar situações de lazer se caracteriza como uma ofensa ao bem estar do indivíduo e deve ser ressarcida. 49

AGRAVO DE INSTRUMENTO N. 427.357 - RJ (2201/0140739-3)

Relator: Ministro Ruy Rosado de Aguiar

Agravante: Hotéis Othon S/A

Advogado: Jorge Ricardo da Costa Ribeiro e outro

Agravado: Jorge Rodinho Landeiro

Advogado: Gilberto Curi Gomes e Souza

Decisão

Vistos, etc.

O egrégio Tribunal de origem, para reconhecer a existência do dano moral e fixá-lo em 100 (cem) salários mínimos, socorreu-se do exame das provas trazidas aos autos e das circunstâncias fáticas que envolveram o caso:

"O dano moral de quem se desloca de sua residência, para assistir a uma festa e sofre o constrangimento de, ao chegar no local onde fizera antecipadamente uma reserva, descobrir que essa reserva não valia, que o fornecedor, a seu talante, resolvera, unilateralmente, mudar o apartamento, oferecendo-lhe outro, se assim quisesse, é evidente.

O descaso, a total desconsideração para com o consumidor manifestada pelo primeiro apelante, colocando-o, perante sua família, em situação de absoluta inferioridade, vendo-a, na portaria de um hotel, ser recusada, porque o fornecedor decidiu que outro hóspede era melhor do que ele, faz com que ele seja obrigado a indenizar a dor sofrida" (fls. 12/13)

Para rever tal decisão, seria indispensável a reapreciação do conjunto probatório, o que não se admite em sede de recurso especial, diante do enunciado da súmula 7 do STJ.

O valor do dano moral não é exorbitante, pelo que não cabe rever sua estimulação nesta via especial.

O art. 336, e incisos, do CPC não foi prequestionado. Incidência das Súmulas 282 e 356 do STF.

Isso posto, nego provimento ao agravo.

Intimem-se . Publique-se

Brasília (DF), 26 de abril de 2002.

Ministro Ruy Rosado de Aguiar, Relator.

Data da publicação: 03/05/2002 50

49 (Ap.Civ. n. 202.961-0, Comarca de Andradas, Rel Juiz Almeida Melo - TAMG).

50 - STJ - Superior Tribunal de Justiça - Pesquisa textual - Jurisprudência - realizada em 09.05.2003, no site www.stj.gov.com.br .. 
DANO MORAL. DANO MATERIAL. PACOTE TURÍSTICO. Acomodação em hotel de qualidade inferior ao contratado. Translados não realizados conforma o combinado. Solidariedade de todos os participantes da relação de consumo. Má prestação dos serviços caracterizada. Incidência dos artigos 20 e 25 do Código do Consumidor. Honra atingida gerando a obrigação de indenizar. Fixação do quantum observado o principio da razoabilidade. Improvimento do recurso. 51 


\section{VI - A REPARAC̄̃O DO DANO MORAL (COMENTÁRIOS FACE A} APLICAC̄̃̃O NOS MEIOS DE HOSPEDAGEM)

\section{COMENTÁRIOS INICIAIS}

O problema mais sério suscitado pela admissão da reparabilidade do dano moral reside na quantificação do valor econômico a ser reposto pelo ofendido. Quando se trata de dano material, calcula-se exatamente o desfalque sofrido no patrimônio da vítima e a indenização consistirá no seu exato montante. Mas quando o caso é de dano moral, a apuração do quantum indenizatório se complica porque o bem lesado (a honra, o sentimento, o nome, etc.) não se mede monetariamente, ou seja, não tem dimensão econômica ou patrimonial.

Cabe assim, ao prudente arbítrio dos Juízes e à força criativa da doutrina e da jurisprudência a instituição de critérios e parâmetros que deverão presidir às indenizações por dano moral, a fim de evitar que o ressarcimento, na espécie, não se torne expressão de puro arbítrio, já que tal se transformaria numa quebra total de princípios básicos do Estado Democrático de Direito, tais como, por exemplo, o princípio da legalidade e o princípio da isonomia.

Se a vítima pudesse exigir a indenização que bem quisesse e se o juiz pudesse impor a condenação que lhe aprouvesse, sem condicionamento algum, cada caso que fosse ter à Justiça se transformaria num jogo lotérico, com soluções imprevisíveis e as mais disparatadas. Onde estaria, então o amparo que a Constituição assegurou ao princípio da legalidade? Onde iria parar o princípio do tratamento igualitário de todos perante a ordem jurídica?

Já em antigo acórdão do Tribunal de Apelação de Minas Gerais, Amilcar de Castro invocava as lições de Ripert, Pedro Lessa, Clóvis, Planiol, Vanni, entre muitos outros, para afirmar que, na espécie, a indenização não compensa nem faz desaparecer a dor do ofendido. A reparação não compreende, por isso mesmo uma "avaliação da dor em dinheiro". Representa apenas uma forma de tutelar um bem não patrimonial que foi violado. A indenização é feita, então, como maneira de substituir um bem jurídico por outro. (RF 93/529) 
Como a dor não se mede monetariamente, a importância a ser paga terá de submeter-se a "um poder discricionário", mas segundo "um prudente arbítrio dos juizes na fixação do quantum da condenação, arbítrio esse que emana da natureza das coisas". E concluía o D. Desembargador Amilcar de Castro: "Causando o dano moral, fica o responsável sujeito às conseqüências de seu ato, a primeira das quais será essa de pagar um soma que for arbitrada, conforme a gravidade do dano e a fortuna dele responsável, a critério do poder judiciário, como justa reparação do prejuízo sofrido, e não como fonte de enriquecimento”. (Revista Forense 93/529)

Recomendava, ainda, o mesmo decisório que a condenação fosse o pagamento do "que for arbitrado razoavelmente, porque não se trata de enriquecer um necessitado" nem de "aumentar a fortuna de um milionário", mas apenas de "impor uma sanção jurídica ao responsável pelo dano moral causado”. (Revista Forense 93/530) 52

A reparação de danos morais, segundo Aguiar Dias, deve seguir um processo idôneo que busque para o ofendido um "equivalente adequado". Lembra, para tanto, a lição de Lacoste, segundo a qual não se pretende que a indenização fundada na dor moral "seja sem imite". Aliás, "a reparação será sempre, sem nenhuma dúvida, inferior ao prejuízo experimentado, mas, de outra parte, quem atribuísse demasiada importância a esta reparação de ordem inferior se mostraria mais preocupado com a idéia de lucro do que mesmo com a injúria às suas afeições; pareceria especular sobre sua dor e seria evidentemente chocante a condenação cuja cifra favorecesse tal coisa. 53

Uma vez que nenhuma possibilidade há de se medir pelo dinheiro um sofrimento puramente moral, Caio Mário (1986, pág.235) recomenda que se faça um jogo duplo de noções: a) de um lado, a idéia de punição do infrator, que não pode ofender em vão a esfera jurídica alheia; b) de outro lado, proporcionar à vítima uma compensação pelo dano suportado, pondo-lhe o ofensor nas mãos uma soma que não é o pretium doloris. 54

Quanto à punição do culpado, a condenação “não pode deixar de considerar as condições econômicas e sociais dele, bem como a gravidade da falta cometida, segundo um critério subjetivo” observa Caio Mário. Quanto ao ressarcimento, deve responder a um equivalente que a quantia em dinheiro proporciona a vítima "na proporção da lesão sofrida." 55

52 Texto: Humberto Theodoro Júnior - Pareceres Civis . Responsabilidade Civil - Danos Morais e Patrimoniais - Acidente do Trabalho - Ato de Preposto - in Revista dos Tribunais 731/91, pág.104

53 apud DIAS, Aguiar. Da Responsabilidade Civil, Forense. Rio de Janeiro: Forense, 1994, Vol. II, pág. 740 , nota 63

54 PEREIRA, Caio Mário da Silva. Instituições de Direito Civil. 8a. Ed. Vol. II. Rio de Janeiro: Forense, 1986, pág. 235.

55 - idem 
Mais do que em qualquer outro tipo de indenização, a reparação do dano moral há de ser imposta a partir do fundamento mesmo da responsabilidade civil, que não visa criar fonte injustificada de lucros e vantagens sem causa.

E, se em qualquer caso se dá a vítima uma reparação de damno vitando, e não de lucro capiendo, mais que nunca há de se estar presente a preocupação de conter a reparação dentro do razoável, para que jamais se converta em fonte de enriquecimento.56

Se de um lado se aplica uma punição àquele que causa dano moral a outrem, e é por isso que tem de levar em conta a sua capacidade patrimonial para medir a extensão da pena civil imposta, de outro lado tem-se de levar em conta a situação e o estado do ofendido, para medir a reparação em face de suas condições pessoais e sociais. Se a indenização não tem o propósito de enriquecê-lo, tem-se que lhe atribuir aquilo que, no seu estado, seja necessário para proporcionar-lhe apenas a obtenção de "satisfações equivalentes ao que perdeu”.

\section{REPARAÇÃO DO DANO MORAL}

Durante muito tempo persistiu o entendimento de que o chamado dano puramente moral não poderia ser indenizado, uma vez que não poderia ser avaliado em pecúnia.

Esta linha de orientação jurisprudencial era seguida pelos Tribunais estaduais, que em algumas oportunidades, timidamente, embora reconhecendo que "o dano moral não é reparável”, aceitavam a tese da reparabilidade dos danos morais indiretos ou dos danos morais com reflexos patrimoniais.

O entrave à admissibilidade da reparação do dano moral imposto pela jurisprudência foi, entretanto, pouco a pouco, cedendo à influência das pregações doutrinárias sob o

56 - idem 
argumento de que "não é o dinheiro, mas a dor, o espanto, a emoção, a vergonha, a injúria física ou moral, em geral uma dolorosa sensação experimentada pela pessoa, atribuída à palavra dor o mais largo significado, vinha solapando o entendimento dos tribunais”57

Atualmente, a aceitação da tese da reparabilidade do dano moral, pode-se afirmar, tornou-se pacífica, depois de haver percorrido um controvertido caminho, e as próprias legislações de diferentes países acolhem a regra de que o prejuízo extrapatrimonial é uma ocorrência que, tanto como o dano patrimonial, enseja indenização.

De um modo geral, a condenação com que se busca reparar o dano moral é representada, na essência, por uma quantia em dinheiro a ser paga de imediato, sem prejuízo de outras cominações secundárias, nas hipóteses de ofensa à honra e credibilidade das pessoas.

Formas de reparação do dano moral:

Admitem-se, nesse campo, conforme a natureza da demanda e à repercussão dos fatos, várias formas de reparação, algumas expressamente contempladas em lei, outras implícitas no ordenamento jurídico positivo, como: a realização de ação, como a de retratação que, acolhida pode satisfazer o interesse lesado (Lei 5.250/67, arts. 29 e 30); o desmentido, ou retificação de notícia injuriosa, nos mesmos termos (idem); a divulgação imediata de resposta (idem); a republicação de material com a indicação do nome do autor (Lei 5.988/73, art.126); a contrapropaganda, em casos de publicidade enganosa ou abusiva (Lei. 8.078/90, art. 60); a publicação gratuita de sentença condenatória (Lei 5.250/67), art. 68), ou sob expensas do infrator ( Lei 8.078/90, art. 78): a divulgação de reclamações fundamentadas contra fornecedores de produtos e serviços (idem. Art. 44). 58

57 MINAZZI, Alfredo. "Studio sul danno non patrimoniale. Società Editrice Libraria, Milano. 1917, pág. 29, apud Tereza Ancona Lopez de Magalhães. Dano Estético Responsabilidade Civil.

58 BITTAR, Carlos Alberto. Reparação civil por danos morais. São Paulo: Revista dos Tribunais,1992, no 35 , pág. 218. 
Na relação de consumo, no que tange a dano moral na hospitalidade, é objetiva a responsabilidade civil dos meios de hospedagem, já que são prestadores de serviços a destinatário final, conforme se insere do disposto no artigo 14 de Lei 8.078, que dispõe “o fornecedor de serviços responde, independentemente da existência de culpa, pela reparação dos danos causados aos consumidores por defeitos relativos à prestação dos serviços, bem como por informações insuficientes ou inadequadas sobre sua fruição $e$ riscos."

Dano moral não é substituto para o dano material não provado. Observe que ele apenas se configura diante de um trauma psicológico, de uma situação que abale gravemente a vida da vítima.

Restando provado que houve dano à moral do consumidor ou de terceiro, e comprovada a participação lesiva do fornecedor no evento, esse deverá ressarcir os prejuízos oriundos do ilícito praticado. É de propriedade da lei a previsão da reparalidade dos danos morais decorrentes do sofrimento, de perturbações emocionais e psíquicas, do constrangimento, da angústia ou do desconforto espiritual, causados por um bem ou serviço defeituoso ou inadequadamente fornecido.

\section{A PROVA NO DANO MORAL}

Refere-se à prova do fato que gerou a dor, o sofrimento, os sentimentos íntimos que o ensejam.

Para configurar o dano moral é imprescindível a sua comprovação, não bastando a mera alegação da pessoa, física ou jurídica, de ter sido vítima de um ato que lhe causou constrangimentos, atribulações, dor ou prejuízo

Regra geral, "no plano do dano moral não basta o fato em si do acontecimento, mas, sim a prova de sua repercussão, prejudicialmente moral” 59 
Mas essa regra não tem sido aplicada em termos absolutos. O tema é bastante debatido e ainda não alcançou uniformidade de entendimento na doutrina e na jurisprudência. Nas posições extremadas estão os que defendem a tese da prova "in re ipsa”, ou seja, que o dano moral se prova por si mesmo, e a dos que sustentam a necessidade da mesma atividade probatória utilizada para a prova do dano material ou patrimonial. Em posição intermediária há os que se contentam com as presunções hominis, ou presunções simples, também ditas comuns, que se formam na consciência do juiz e que, como afirma Moacyr Amaral Santos, "são as conseqüências que o juiz, como homem, e como qualquer homem criterioso, atendendo ao que ordinariamente acontece (quod plerumque accidit), extrai os fatos da causa, ou suas circunstâncias, e nas quais assenta sua conviç̧ão quanto ao fato probando”.60

De qualquer forma, põe-se em evidência como pressuposto da obrigação de reparar o dano moral o nexo de causalidade entre a ação ou omissão voluntária e o resultado lesivo.

Em alguns casos, como na hipótese de ofensa à honra, por calúnia, difamação ou injúria, o dano moral está ínsito na ofensa e dessa forma se prova por si. O dano moral emerge "in re ipsa" das próprias ofensas cometidas, sendo de difícil, para não dizer impossível, averiguação.

Em outras hipóteses, entretanto, a prova do dano moral está submetida ao regime geral das provas, de modo que o ônus da prova incumbe a quem alega ter sofrido o dano moral (art. 333, n. I, do Código de Processo Civil). Fato alegado e não provado, é o mesmo que fato inexistente - allegatio et non probatio, quasi non allegatio.

Entretanto, nessa matéria de prova do dano moral não se poderá exigir uma prova direta. Não será, evidentemente, com atestados médicos ou com o depoimento de duas ou três testemunhas, que se demonstrará a dor, o sofrimento, a aflição, em suma, o dano moral alegado por aquele que pleiteia, em juízo, a reparação. Admissível, por conseguinte, que o dano moral seja demonstrado por meio de presunções hominis.

Para tanto, o Juiz, na falta de regras jurídicas particulares, poderá aplicar as regras de experiência comum subministradas pela observação do que ordinariamente acontece, como expressamente o autoriza o art. 335 do Código de Processo Civil. 61

59 CAHALI, Yussef Said. Dano Moral. Revista dos Tribunais. $2^{a}$ ed. São Paulo: 2000. pág. 703.

60 "Primeiras Linhas de Direito Processual Civil”, vol. 2, pág. 441), baseadas no critério da anormalidade ou em certos "standards" jurídicos, como afirmam ANNABEL GARAT e CARLOS SACCHI ("Manual de responsabilidade extracontractual”, tomo I, pág. 188), citados por BEATRIZ VENTURINI (ob. cit., pág. 123). 
Também, nada impede o Juiz de presumir, mesmo porque os princípios gerais da prova lhe permitem levar em conta as presunções, em consonância com as regras da experiência, a existência da dor, da angústia, da aflição, do desespero sofridos. Porém, a presunção hominis é relativa, ou juris tantum, e admite prova em contrário.

Apenas dependem de prova os fatos controvertidos. Os fatos admitidos no processo como incontroversos não dependem de prova (art. 334, nº. III, do CPC). Dessa regra decorre o corolário de que os fatos evidentes não necessitam de prova, mesmo porque a prova deles seria inútil. Ao réu é que cabe apresentar elementos que impeçam a elaboração da presunção hominis.

Ainda com relação à matéria de prova de dano moral é importante observar que o Código de Defesa do Consumidor, como já citado anteriormente, faz previsão à efetiva reparação de danos morais que possam os consumidores ter sofrido na relação de consumo, além da responsabilidade material.

Quando um serviço turístico agride a expectativa do consumidor, ou ocorre um acidente de consumo, já se teve a incidência de dano moral.

O que mais importa para caracterizar o dano, principalmente o moral, é a prova do fato constitutivo de seu direito e que esse procedimento decorreu de sua condição de consumidor.

\section{LEGITIMIDADE PARA PLEITEAR A INDENIZAÇÃO}

A reparação do dano moral sofrido deverá ser pleiteada por quem detém a legitimatio ad causam, ou seja, exclusivamente pelo próprio lesado.

61 VALLER. Wladimir. A Reparação do Dano Moral no Direito Brasileiro. $2^{a}$ Ed. Campinas: E. V. Editora Ltda. 1994. 
Importante observar que, embora nas relações de direito comum herdeiros e sucessores da vítima possam reclamar danos materiais e morais decorrentes de acidentes fatais relacionados a contratos de turismo, a reparação do dano moral, nesse caso, está relacionada com a dor da perda do ente querido e não com a frustrações de expectativas do contrato em si ou que aquele que veio a falecer tenha sofrido.

ÔNIBUS DE TURISMO - ACIDENTE - Morte ocorrida em conseqüência de acidente em ônibus de turismo acarreta dever da empresa de transportes, de indenizar a família não apenas por danos materiais, mas também por danos morais como recompensa que vise a amenizar o sentimento do ente querido. Fundamentos: artigo 37 , parágrafo $6^{\circ}$ da Constituição Federal.. 62

\section{DA FIXAÇÃO DO QUANTUM INDENIZATÓRIO}

Inexistem parâmetros legais para o arbitramento do valor de reparação do dano moral, na medida em que lhe são atribuídos valores casuísticos esparsos em dispositivos do Código Civil e Legislação especial. Mesmo porque cada indivíduo possui um contexto social, um comportamento e moralidade própria na medida que é detentor de um patrimônio pessoal que lhe é único. O nível intelectual, social e econômico de um indivíduo estabelece padrões de comportamento que influem na construção das regras de moralidade pessoal e social.

Para fixação do quantum a indenizar numa relação que enseja o dano moral, faz-se mister uma minuciosa análise para averiguar se o ato ilícito praticado realmente contrariou a moral do titular do direito abalado.

O ato ilícito por ação ou omissão gera ao autor da lesão a obrigação de reparar o dano, e essa reparação de natureza pessoal se resolve pelo pagamento de uma quantia em dinheiro.

62 Súmula 37 - STJ ( TJDF - 1ª T. Civil, Ap. Civil 5011598-DF; rel. Eduardo de Moraes Oliveira; 26.10.98; DJDF 20.04.99 - pág. 120) 
Segundo a melhor doutrina, o critério para fixar o quantum indenizatório é exclusivo do Juiz. Cabe a ele arbitrar, portanto, o quantum a ser pago pelo ofensor. Trata-se de uma das tarefas mais difíceis para o Magistrado, pois ele tem de estipular um valor de dinheiro para reparar um sofrimento pessoal. Como é sabido, o dinheiro não recompõe a integridade física, psíquica ou moral lesada de alguém. É apenas uma consolação para amenizar a dor da vítima ou de seus familiares. Mas é uma punição também para aquele que causou o dano e deve ser uma quantia que reprima nele, no futuro, atitudes semelhantes. Para tanto, o valor da condenação não deve ser além das possibilidades também de pagamento do acusado, pois, se a quantia for muito alta, o acusado torna-se também uma vítima. O Juiz tem de levar em conta, nesse caso, a capacidade de pagar do agressor e dosar sua decisão nesse sentido. Isso significa que o valor fixado pelo Juiz não pode levar, também, ao enriquecimento sem causa da vítima e nem causar, como se disse anteriormente, a miséria do acusado.

Para fixação do quantum em indenização por danos morais, são levados em conta: a capacidade econômica do agente; seu grau de culpa ou dolo; a posição social do ofendido; a prova da dor; as circunstâncias particulares do caso; a extensão dos prejuízos causados; isso, porém, não pode ser meio de enriquecimento de quem o reclama, devendo, ademais, ser suficiente para incutir, naquele que o presta, o receio de incidir no mesmo fato, cingindo-se sempre ao princípio da razoabilidade na sua fixação.

\section{DAS EXCLUDENTES DE INDENIZAÇÃO}

As causas ou cláusulas exonerativas de responsabilidade são fatores presentes em nosso Direito. O douto Sérgio Cavalieri atesta que a “cláusula exonerativa não exime a responsabilidade ou o dever de indenizar na obrigação assumida; o que ocorre é o afastamento da reparação do dano”. 64

64 CAVALIERI FILHO, Sérgio. Programa de Responsabilidade Civil. Rio de Janeiro: Malheiros, 1999. 
No âmbito civil, a exclusão ou diminuição da responsabilidade de indenizar ocorrerá nos seguintes casos:

a) por culpa exclusiva da vítima: a vítima arcará com todos os prejuízos oriundos do evento danoso causado exclusivamente por ela;

b) por caso fortuito ou força maior - aqui restam presentes dois requisitos: um de ordem objetiva, pela inevitabilidade do evento, e outro de ordem subjetiva, pela ausência de culpa na produção do acontecimento. Cessa-se, então, a responsabilidade do agente;

c) por culpa concorrente da vítima e do agente: cada um responderá pelo dano, na proporção em que concorreu para ele. Haverá, nesse caso, uma atenuação da responsabilidade, caso em que a indenização será, em regra, devida pela metade; mas pode ser maior que a outra ou igual, caso em que inexistirá qualquer indenização por perdas e danos, pela compensação de culpas;

d) por culpa de terceiro: se alguém for demandado para indenizar um prejuízo que lhe foi imputado pelo autor, poderá pedir a exclusão de sua responsabilidade se a ação que provocou o dano foi devida exclusivamente a terceiro. Para haver a exoneratória do fato de terceiro será necessário: 1) que o dano se ligue ao fato de terceiro por relação de causa e efeito; 2) que o fato de terceiro não tenha sido provocado pelo ofensor, para não haver culpa ocorrente; 3) o fato de terceiro ser ilícito; 4) que o fato seja normalmente imprevisível e inevitável, embora não precise provar sua absoluta irresistibilidade e imprevisibilidade. Mas a jurisprudência tem-se inclinado ao entendimento de não ser cabível tal excludente no caso de transporte, pois, havendo dano, e a culpa sendo de terceiro, o transportador deverá responder pelo dano e, posteriormente, ingressar com a ação regressiva contra o terceiro. Ou seja, o sujeito ou fornecedor responde e paga e, depois, se ressarce do terceiro culpado.

\section{RESPONSABILIDADE DOS COMERCIANTES:}


Ainda com relação a acidentes de consumo, o comerciante, tratado por alguns como parte subsidiária e por outros como parte fundamental, no entender da maioria dos juristas, pode ser responsabilizado de duas formas: a) como terceiro, nos termos do artigo $12, \S 3^{\circ}$, III, se ficar demonstrada sua culpa exclusiva no evento danoso; b) como parte, de forma subsidiária, em havendo o dano não puder identificar o fornecedor ou produto (artigo 13, I e II) ou quando não conservar adequadamente os produtos perecíveis (inc.III).

Todas as causas excludentes da responsabilidade civil devem ser devidamente comprovadas e examinadas com cuidado pelo órgão judicante, por importarem exoneração do ofensor, deixando o lesado sem a composição do dano sofrido.

Além daquelas excludentes ou atenuantes, há na seara contratual a cláusula de não indenizar.

Quanto à cláusula de não indenizar, ela vai se formar por consentimento bilateral, em que haverá a anuência das partes contratantes. Ela visa à anulação, modificação ou restrição das conseqüências normais de um fato da responsabilidade do beneficiário da estipulação.

Essa cláusula provoca muita divergência no tocante a sua aceitação e só será admitida em determinados casos. A sua admissão tem por base a questão da autonomia da vontade convergente de partes contratantes, com a condição de que ela não venha a ferir a ordem pública e os bons costumes.

Assim, quando o contrato de turismo apresentar qualquer tipo de problema, seja por defeito, por vício, por acidente, ou por descumprimento da oferta, o dano moral já existiu e deve ser efetivamente reparado.

Observe que essa garantia de reparação dos danos patrimoniais ou morais do consumidor não pode ser derrogada por convenção das partes. Tratando-se de normas legais imperativas, que dizem respeito ao direito subjetivo do consumidor ao ressarcimento, são irrenunciáveis $e$ inderrogáveis, sendo nulas de pleno direito as cláusulas contratuais relativas ao fornecimento de produtos e serviços que "impossibilitem, exonerem ou atenuem a responsabilidade do fornecedor por vícios de qualquer natureza dos produtos e serviços ou impliquem em renúncia ou disposição 
de direitos (art. 51, n I, primeira parte). 65 Também expressamente previsto no Artigo 25 do CDC que dispõe ser "vedada a estipulação contratual de cláusula que impossibilite, exonere ou atenue a obrigação de indenizar”, tanto no que diz respeito à responsabilidade pelo fato, como pelo vício do produto ou do serviço.

Essas estipulações são comuns nos casos de fornecimentos de serviços, como se verifica em hotéis, shopping centers, estacionamento de veículos, etc., que costumam advertir seus clientes de que não se responsabilizam pelos objetos ou valores pessoais deixados no interior de veículos ou pelo furto de bens e valores que não tenham sido confiados à guarda do estabelecimento comercial.

No âmbito das relações de consumo, a cláusula de não indenizar é inadmissível. Isso acontece porque no próprio art. $6^{\circ}$ do Código de Defesa do Consumidor está prevista a indenização por Danos Morais ou Patrimoniais ocorridos. As normas de proteção e defesa ao consumidor são tidas como normas de Ordem Pública e por isso são inderrogáveis pelas partes.

Importante frisar que, nesses casos, para afirmar seu direito, embora não tenha que provar a culpa do hotel, a parte interessada deve preliminarmente provar a existência do bem e seu valor.

INDENIZAÇÃO. DANOS EM VEÍCULO EM ESTACIONAMENTO. FORNECEDOR DE SERVIÇOS. CONTRATO DE DEPOSITO E O DEVER DE GUARDA - 1. É dever de guarda e conservação da coisa depositada que emerge a obrigação indenizatória, sustentada na presença da culpa in vigilando. 2. É objetiva a responsabilidade do fornecedor de serviços pelos prejuízos materiais ou morais, segundo normatividade do Código de Defesa do Consumidor, só se livrando da obrigação de indenizar provando a culpa exclusiva da vítima. 66

65 VALLER, Wladimir. A reparação do dano moral no direito brasileiro. E.V. Editora Ltda. Campinas: 1994, pág. 179.

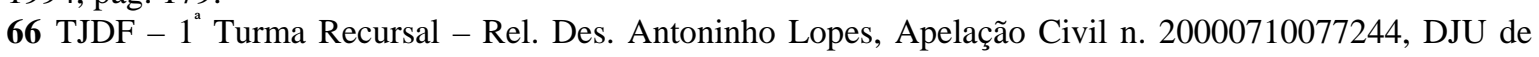
21.09.2001, pág. 219. 
Por tudo, é importante esclarecer:

a) - que no exercício de um direito legítimo não cabe o dano moral;

b) em casos de conduta ilícita, inclusive por abuso de direito ou exercício anti-social de direito, pode ser cabível o dano moral;

c) que a agressão a direito personalíssimo deve ser insuportável diante dos padrões normais de avaliação social e suscetível de gerar sofrimento íntimo ou desconsideração social;

d) que o sofrimento deve decorrer de agressão à honra, à intimidade, à vida privada, à imagem e a outros direitos personalíssimos, propulsores da caracterização do dano moral;

e) que as circunstâncias que envolvem o fato, assim a intensidade, a injustiça ou a ilegalidade da atentadora agressão, as condições pessoais dos envolvido e o modo e intenção do uso de palavras, gestos ou atitudes são fatores que devem ser considerados na caracterização do dano moral.

\section{DA PRESCRIÇÃO}

No Código de Defesa do Consumidor, no geral, sendo a responsabilidade por fato do produto ou serviço (Artigo 12 do CDC), o prazo para reclamar é de prescrição em 05 (cinco) anos (Artigo 27 do CDC); sendo a responsabilidade originária de vício, surge o prazo decadencial (Artigo 26 do CDC).

O início desse prazo prescricional começa a fluir com a presença, cumulativa, dos seguintes requisitos: 1) o conhecimento do dano (cabendo ao consumidor ter a percepção necessária deste) e 2) a identificação da autoria, ou seja, a identificação da responsabilidade pelo evento. 
Quando se tratar de dano moral puro, a prescrição ocorre em 10 (dez) anos, conforme disposto no Código Civil, Artigo 205. 


\section{VII - SOLUÇÕES JUDICIAIS E EXTRAJUDICIAIS}

O Código e os órgãos de defesa do consumidor devem ser acionados a partir do momento em que o consumidor se sentir lesado durante ou após contratar com algum produto ou serviço. Seus direitos estão claramente expressos no Código, que está cada vez mais respeitado no Brasil.

Mas, para que a lei possa surtir efeitos práticos, três fatores são determinantes: a reeducação do consumidor que precisa conhecer seus direitos, o trabalho contínuo e integrado dos órgãos de defesa e a conscientização dos fornecedores de produtos e serviços.

No momento em que o problema surge, É NECESSÁRIO QUE SEJAM RESGUARDADOS OS DIREITOS, principalmente quando envolver Dano Moral. Assim, o lesado poderá:

- dirigir-se ao PROCON; para registrar sua queixa e pedir ressarcimento de danos materiais;

- acionar criminalmente (se for o caso) através da DECON (Delegacia de Defesa do Consumidor), da Delegacia do Turista ou mesmo da Delegacia de Polícia. A DECON tem a função de investigar crimes praticados contra os consumidores, previstos tanto no Código de Defesa do Consumidor quanto em outras legislações.As autoridades policiais não aplicam multas, trabalham na investigação dos fatos, por meio de um Inquérito Policial que pode ser iniciado a partir da ocorrência policial formulada pelo consumidor lesado ou com a prisão dos envolvidos em flagrante. Encerrada essa fase de investigação, o Inquérito Policial é remetido à Justiça Criminal, cabendo ao Promotor de Justiça iniciar ou não o processo crime, que só terminará com a decisão do Juiz;

- informar a EMBRATUR ou órgãos competentes para fiscalização; 
- ou, ainda, se dirigir diretamente ao Poder Judiciário, para requerer danos morais e materiais.

\section{1 - SOLUÇÕES EXTRAJUDICIAIS: APENAS PARA DANOS MATERIAIS}

Atualmente existem no Brasil vários órgãos públicos responsáveis pelo exercício de coordenação e execução da política de proteção, amparo e defesa do consumidor, mas, com referencia a ressarcimento de dano moral, apenas o judiciário será competente para apreciar e julgar.

\section{PROGRAMA DE ORIENTAÇÃO DO CONSUMIDOR - PROCON}

O PROCON é uma fundação de direito público vinculada à Secretaria de Justiça e da Defesa da Cidadania dos Estados. É o principal órgão de defesa do consumidor.

Como órgão representante dessa política de privilégio e preservação dos direitos do consumidor, tem as funções de orientar, receber, analisar e encaminhar as relações, consultas e denúncias de consumidores, além de fiscalizar preventivamente os direitos do consumidor e, oportunamente, aplicar as devidas sanções, quando estas se apresentarem procedentes e cabíveis.

Nacionalmente, esse organismo de defesa do consumidor, que tanto pode representar-se em nível municipal quanto estadual, encontra-se presente em todos os Estados brasileiros, podendo também fazer-se representar através do Ministério Público.

Como órgão público, representante dos interesses dos cidadãos enquanto clientes/consumidores que se sentem eventualmente lesados por seus fornecedores, o PROCON oferece atendimento gratuito, podendo o consumidor fazer suas reclamações diretamente, sem necessidade de fazer-se representar por advogado. 
Para que possa efetivamente exercer sua primordial função de atuar como órgão de defesa do consumidor, o PROCON estabeleceu normas que devem ser estritamente observadas pelos reclamantes, quando da reveindicação de seus direitos face a eventuais danos e/ou perdas sofridas na condição de clientes consumidores, perante seus fornecedores.

Assim, sempre que o cidadão sentir-se lesado, enganado ou prejudicado como cliente/consumidor e mesmo após reclamar ao estabelecimento responsável não obter nenhum sucesso ou atenção, deve recorrer ao PROCON.

a) As queixas devem ser feitas, de preferência, pessoalmente nos postos do PROCON, mas o atendimento no PROCON pode ser realizado por telefone, por correspondência (relatando o fato) ou através de denúncia on line; no entanto, documentos comprovantes da relação de consumo, como registros, faturas, notas fiscais, recibos, contratos, etc. (podendo ser cópias) devem ser enviados ou anexados. Ressalte-se que a reclamação “formalizada” só poderá ser registrada pessoalmente.

b) O PROCON receberá a queixa e verificará se é procedente. Confirmado o fato, o PROCON notifica a empresa da reclamação e presta os devidos esclarecimentos. O prazo de resposta para a empresa é de 10 (dez) dias. Se a empresa não se pronunciar quanto ao problema, o PROCON formaliza a reclamação e um novo aviso é enviado à empresa, convocando-a para uma reunião de conciliação; não ocorrendo o acordo, o PROCON orienta o consumidor a entrar com processo judicial no Juizado Especial de Pequenas Causas. A empresa que não atender à segunda notificação do PROCON pode ser julgada à revelia.

c) Com os poderes de impor sanções administrativas, o PROCON pode multar, apreender ou inutilizar o produto, cassar o registro do produto juntamente ao órgão competente e até proibir a sua fabricação. Além disso, pode suspender o fornecimento do produto ou serviço e, temporariamente, a atividade, revogar a concessão ou permissão de uso, cassar a licença do estabelecimento ou da atividade e impor a contrapropaganda.

\section{2 - SOLUÇÕES JUDICIAIS - PARA DANOS MORAIS E MATERIAIS}


O lesado poderá recorrer à justiça comum para buscar ressarcimento de seus prejuízos materiais ou indenizações por danos morais sofridos. Se optar por uma maior celeridade e eficácia no acesso à justiça, poderá valer-se dos Juizados Especiais Cíveis, criados pela Constituição Federal de 1998, em seu inciso I, do artigo 98, visando destinar ao cidadão um fácil acesso à justiça e sua rápida resolução.

\section{JUIZADOS ESPECIAIS CÍVEIS}

Em 26/09/1995 foi sancionada a Lei dos Juizados Especiais Cíveis e Criminais que dispõe sobre vários procedimentos desse "novo” órgão que integra o Poder Judiciário, orientado pelos critérios da simplicidade, informalidade, rapidez e economia processual, buscando sempre a conciliação entre as partes.

Essa é, a principal razão da eficácia dos Juizados, permitindo que a maioria dos casos sejam resolvidos na primeira audiência, quando se busca conciliação entre as partes litigantes.

Dividem-se os Juizados Especiais em:

- Juizados Cíveis, que têm por finalidade julgar pedidos de reparação por danos que não ultrapassem 40 salários mínimos; e

- Juizados Criminais, que têm por finalidade resolver delitos de pouca gravidade.

Para manter a rapidez processual, essa lei definiu vários critérios, entre os quais destacam-se:

- propositura de ações, nos Juizados Especiais, restrita às pessoas físicas, capazes maiores de 18 anos e às microempresas; 
- gratuidade de custos da ação, desde sua propositura até sua decisão;

- ocorrência de pagamento de custas judiciais, taxas e outras despesas apenas no caso de interposição de recurso por uma das partes.

Além disso, os mencionados Juizados têm competência para conciliação, processo e julgamento de causas cíveis de menor complexidade, assim consideradas:

- as causas cujo valor não exceda o valor de quarenta vezes o salário mínimo;

- as causas enumeradas no artigo 275, inciso II, do Código de Processo Civil;

- a ação de despejo para uso próprio;

- as ações possessórias sobre bens imóveis de valor não excedente a quarenta vezes o salário mínimo;

- os títulos executivos extrajudiciais (promissórias, cheques, contratos),no valor de até quarenta vezes o salário mínimo;

- a cobrança de ressarcimento de danos (como, por exemplo, os danos decorrentes de acidentes de trânsito); e,

- as ações consignatórias.

Ficam excluídas da competência dos Juizados Especiais as causas de natureza alimentar, falimentar, fiscal e de interesse da Fazenda Publica e também aquelas relativas aos acidentes de trabalho, aos resíduos e ao estado e capacidade de pessoas, ainda que de cunho patrimonial.

Advogados:

- até 20 salários mínimos, a atuação do advogado é opcional, ou seja, não constitui requisito obrigatório para o ingresso da reclamação;

- até 40 salários mínimos, a atuação do advogado é obrigatória, ou seja, é requisito obrigatório para o ingresso da reclamação; 
- acima de 40 salários mínimos, o processo deverá ser ingresso com advogado em Vara Comum, isto é, em Vara Cível;

- caso a outra parte se apresente acompanhada de advogado, o Juiz nomeará (em audiência) um advogado para o autor, nos termos da lei local.

A mentalidade de muitos empresários brasileiros ainda continua direcionada apenas para a obtenção de lucros, esquecendo-se de satisfazer as pretensões dos consumidores, que adquirem seus produtos ou contratam seus serviços.

Em conformidade com os requisitos da Lei 9.099/95, as ações propostas contra agências de viagem podem, também, constituir-se através de demandas no Juizado das Reações de Consumo ou no Juizado Especial Cível (quando não houver o primeiro).

Tornou-se mais fácil e rápido para o turista/consumidor lesado responsabilizar as agências de viagem pelos danos/vícios dos produtos/serviços oferecidos e/ou prometidos.

Como principais reivindicações incluem-se aquelas relacionadas ao transporte (extravio de bagagem, overbooking), aos hotéis (de categoria inferior), em suma, ao descumprimento de acordo relativo à oferta/publicidade e suas possíveis reparações por danos morais. 


\section{CONSIDERAÇÕES FINAIS}

1. No sistema de turismo e hospitalidade, em que a atividade é de livre iniciativa, lucrativa e que se inclina a satisfazer os anseios de diversão e lazer de consumidor final, aqueles que nela atuam encaixam-se como fornecedor, portanto, sua relação com o consumidor/hóspede/cliente é regida pelo Código de Defesa do Consumidor.

2 . Por tudo o que foi exposto, percebe-se que estar diante de uma relação de consumo é estar diante de um sistema próprio que possui desde uma Política Nacional, princípios, regras próprias, inclusive com imputação, com objetivo de equilibrar os dois pólos da relação, atendendo assim ao princípio da isonomia previsto no Texto Constitucional, basilar do Estado Democrático de Direito.

3. O contrato de turismo ou hospitalidade, quando não realizado de forma adequada, gera ao consumidor, além dos danos materiais, danos morais, pois tira a essência da contratação que é o descanso ou lazer.

4. A oferta na prestação de serviços de turismo e hospitalidade não pode conter informações vagas , confusas ou obscuras, sob pena de arcar com a responsabilidade.

5. Os fornecedores, diante da oferta publicitária, são solidários em toda responsabilidade pela prestação de serviços de turismo e hospitalidade. 
6. Diante de condutas de agentes do trade turístico, que buscam a todo momento, meios para aumentar seus lucros na exploração de serviços turísticos, mas mantêm-se indiferentes à necessidade de direcionar uma parcela de seus lucros para atender ou ressarcir reclamações relativas à má prestação de seus serviços, o turista lesado ainda depara-se com dificuldades no reparo de sua frustração em relação aos serviços prestados pelas Agências e Meios de Hospedagem.

7. O dano moral requer indenização autônoma, cujo critério será o arbitramento, ficando este a cargo do Juiz, que, usando de seu prudente arbítrio e à luz das provas produzidas, fixará o valor do quantum indenizatório. Para isso deverá verificar as condições das partes, o seu nível social e grau de escolaridade, bem como o prejuízo sofrido pela vítima, a intensidade da culpa e os demais fatores concorrentes para a fixação do dano.

8. Por outro lado, a indenização deverá ser paga em dinheiro, para que o ofensor sinta de alguma forma o mal que praticou, sabendo-se de antemão, entretanto, que o valor fixado jamais será suficiente para compensar integralmente a perda ou sofrimento, procedendo-se tão-só de forma a facultar ao beneficiário, condições materiais para minimizá-la, da forma que melhor lhe aprouver.

9 . A indenizabilidade do dano moral desempenha uma função tríplice: reparar, punir, admoestar ou prevenir. 


\section{REFERÊNCIAS BIBLIOGRÁFICAS}

ALVIM, Thereza. Código do consumidor comentado. Rio de Janeiro: Forense, 1997.

BENI, Mário Carlos. Análise estrutural do turismo. São Paulo: Senac, 1998

BENJAMIM, Antônio Heran. Comentários ao código de defesa do consumidor- Direito material. São Paulo: Saraiva, 2000.

BITTAR. Carlos Alberto. Reparação civil por danos morais. São Paulo: Editora Revista dos Tribunais, 1994.

CAHALI, Yussef Said. Dano moral. São Paulo: Revista dos Tribunais, 2000.

CAVALIERI FILHO. Sérgio. Programa de responsabilidade civil. Rio de Janeiro: Malheiros, 1999.

DINIZ, Maria Helena. Curso de direito civil brasileiro: teoria geral das obrigações. Vol. II. São Paulo: Saraiva, 1984.

DINIZ, Maria Helena. Curso de direito civil brasileiro. Vol. II. São Paulo: Saraiva, 1988.

FILOMENO. José Geraldo de Brito. Código de defesa do consumidor comentado pelos autores do anteprojeto. 7.ed. Rio de Janeiro: Forense Universitária, 2001.

GRINOVER. Ada Pelegrini ...[et al]. Código de defesa do consumidor: comentado pelos autores do anteprojeto. 3. ed. Rio de Janeiro: Forense Universitária, 1993

JUNIOR, Cretela. Tratado. Vol.III. Rio de Janeiro: Forense; 1970

LISBOA. Roberto Senise. Responsabilidade civil nas relações de consumo. São Paulo: Universidade de São Paulo, 2000 (tese de doutorado)

MAMEDE, Gladston. Direito do turismo: legislação específica aplicada. São Paulo: Atlas, 2002.

MAMEDE, Gladston. Manual de direito para administração hoteleira. São Paulo: Atlas, 2002.

MAROTTA. Wander. Indenização por dano moral no turismo. In Congresso Brasileiro de Direito do Consumidor. Revista do Consumidor, n. 37. São Paulo: Editora Revista dos Tribunais, jan-mar/2001

MARQUES, Cláudia Lima. Contratos no código de defesa do consumidor. 3. ed. São Paulo: Revista dos Tribunais, 1999. 
NERY JUNIOR. Nelson. Código de defesa do consumidor comentado pelos autores do anteprojeto. Rio de Janeiro: Forense Universitária, 2001.

NERY JUNIOR. Nelson. Os princípios gerais do código brasileiro de defesa do consumidor, Revista do Direito do Consumidor n. 33. São Paulo: Editora Revista dos Tribunais, jan-mar/2000

NIETO, Marcos Pinto Nieto. Manual de direito aplicado ao turismo. Campinas/SP: Papirus, 2001.

NUNES, Luiz Antonio Rizzato; CALDEIRA, Mirella D’Angelo. $\underline{\mathrm{O} \text { dano moral e sua }}$ interpretação jurisdicional. São Paulo: Saraiva; 1999.

NUNES, Luiz Antonio Rizzato. Comentários ao código de defesa do consumidor. direito Material. São Paulo: Saraiva, 2000,

PEREIRA, Caio Mário da Silva. Instituições de direito civil, 8. ed. vol. II. Rio de Janeiro: Forense, 1986

PINTO, Antonio Carlos Brasil. Turismo e meio ambiente / aspectos jurídicos. Campinas/SP : Papirus, 1998.

ROCHA, Silvio Luiz Ferreira. O código de defesa do consumidor e sua interpretação jurisprudencial. São Paulo: Saraiva, 1997,

STOCO, Rui. Responsabilidade civil e sua interpretação jurisprudencial, 2. ed. São Paulo: Editora Revista dos Tribunais, 1995.

TEPEDINO. Gustavo. A responsabilidade nos contratos de turismo. Revista do Consumidor n. 26. São Paulo: Editora Revista dos Tribunais, abr-jun/1998.

VALLER, Wladimir. A reparação do dano moral no direito brasileiro. São Paulo: E.V. Editora Ltda., 1994.

\section{Códigos:}

Código Civil Brasileiro

Código Brasileiro de Defesa do Consumidor

Constituição Federal do Brasil de 1988.

\section{Revistas}

Viagem e turismo. Editora Abril / vários números/2001/2002/2003.

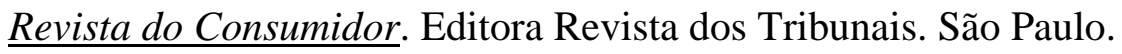




\section{ANEXOS}

\section{JURISPRUDÊNCIAS NACIONAIS}

\section{a) Responsabilidade / Solidária / Pluralidade de Fornecedores Participantes da relação de consumo}

PACOTE TURÍSTICO. ACOMODAÇÃO EM HOTEL DE QUALIDADE INFERIOR AO CONTRATADO. Traslados não realizados conforme o combinado. Solidariedade de todos os participantes da relação de consumo. Má prestação dos serviços caracterizada. Incidência dos artigos 20 e 25 do Código do Consumidor.

(Turma Recursal - RJ, Juiz Cleber Ghefstein, j. 10/04/99).

CONSUMIDOR - PACOTE TURÍSTICO - HOSPEDAGEM EM HOTEL INFERIOR AO CONTRATADO - Pluralidade de fornecedores do serviço - Responsabilidade entre eles, independente de culpa.

Ementa da relação: havendo pluralidade de fornecedores de serviço haverá solidariedade entre eles, visto que esta tem fundamento no bom adimplemento dos contratos e não na culpa de um dos fornecedores. Portanto, contratada hospedagem em hotel cinco estrelas e colocado à disposição do consumidor estabelecimento de categoria inferior, responde solidariamente tanto a empresa responsável pela sua execução.

(Ap.Civ. n. 1.968-4/9, 7. Câmara TAMG, rel. Juiz Júlio Vidal, j. 06/08/97)

PACOTE TURÍSTICO. DESCUMPRIMENTO DO CONTRATO. Responsabilidade solidária. Empresa vencedora de pacote turístico é, "lato sensu”, prestadora de todos os serviços turísticos que integram o pacote, independentemente da responsabilidade final ou intermediária ser de outras empresas. Princípio da responsabilidade solidária entre todos os autores da ofensa, erigido como direito básico do consumidor pelo artigo $7^{\circ}$, parágrafo único do CDC.

( Apelo improvido. (ApCiv. N. 195151303, TARS, 4.C.Civel, rel. Juiz Moacir Leopoldo Haeser, JTARS 97/276-282,j. em 09/11/95,v.u.) 
CONTRATO. ADESÃO. CLÁUSULA DE REEMBOLSO. AGÊNCIA DE TURISMO. Intermediadora e vendedora de viagens. Ilegitimamente passiva "ad causam”. Contrato tácito, que uma vez aperfeiçoado, vincula e obriga a intermediadora pelos seus termos Preliminar rejeitada. As cláusulas impostas e aceitas por ambas as partes vinculam diretamente ao contrato, tornando a agência diretamente responsável pelo atendimento de quaisquer reclamações dos clientes e, mais do que isso, também pelo reembolso das quantias que eventualmente forem credores”.

(Ap.Civ. n. 2191942, TJSP, 13. Câm., rel. Marrey Neto, j. 14/09/93)

EMBARGOS À EXECUÇÃO. PACOTE TURÍSTICO. DESCUMPRIMENTO DE VÁRIOS ITENS. Anulação da execução. Ação ordinária para anulação de contrato firmado com agência de viagens e pedido de ressarcimento de danos. Julgamento simultâneo. Descumprimento de vários itens do pacote turístico. Sentença de $1^{\circ}$ grau rejeitou os embargos e julgou improcedentes os pedidos da ação ordinária, que restou incontestada. Acolhimento da apelação para inversão do julgamento. As obrigações da agência de viagens incluem o conforto, segurança e bem estar dos viajantes e não apenas a venda dos bilhetes aéreos e reserva de hotéis.

(Ap.Civ. n. 16726/92, 4 Câm., rel. Roberto Wider, j. 04/03/93).

CONTRATO. PRESTAÇÃO DE SERVIÇOS. TURISMO. PACOTE TURÍSTICO NÃO REALIZADO. Excursão que deveria ter sido realizada por operadora contratada por agência de viagem. Hipótese em que a atuação dessa ultima não deve ficar limitada à venda e intermediação do pacote, respondendo referida agência pela idoneidade da operadora, acompanhando, ainda, o cumprimento do contrato. Responsabilidade solidária de ambas reconhecida.

(1 ${ }^{\circ}$ TACiv/SP, rel. Sebastião Thiago de Siqueira, j. 25/08/99)

EMPRESA INTERMEDIÁRIA DE “PACOTE TURÍSTICO” É RESPONSÁVEL SOLIDÁRIA EM CASO DE DANOS AO CONSUMIDOR (artigos 3. E 14 do CDC).

(JECSP, rel. Soares Levada, j. 31/08/95)

RESPONSABILIDADE CIVIL. CONTRATO DE INTERMEDIAÇÃO DE PACOTE TURÍSTICO. Execução defeituosa. Demora no repasse do preço de diária no hotel. Turista retido no hotel. Legitimação passiva da intermediadora de venda de pacote 
turístico decorre de pertinência subjetiva entre aquela relação contratual e a relação processual instaurada na ação. O mau tratamento do imposto a hóspedes em hotel no exterior, em razão de alegada inadimplência, e a conseqüente retenção destes em setor de cobrança do estabelecimento, por si só, causam angústia e vergonha, independentemente da presença ostensiva, ou não, de seguranças, gerando por aquela diante de tal situação, devendo o responsável responder pela respectiva indenização. Alcance de indenização. Inexistindo, no direito brasileiro, parâmetros ou tarifamento para fixação de verbas indenizatórias, salvo hipóteses excepcionais, a estimativa é conferida ao prudente arbítrio do juiz, a ser entendido em conformidade com as circunstâncias peliculares do fato, às condições do lesado e do agente causador do dano. Sentença mantida. Apelos desprovidos.

(Ap. Civ. n. 70000068031, TJRS, 9. Câmara Cível, rel. Des. Mara Larsen Chechi, Julgado em 15/12/99).

EMENTA: INDENIZAÇÃO- EMPRESA DE TURISMO- INFRAÇÃO CONTRATUAL DANO MATERIAL E MORAL - SOLIDARIEDADE LEGITIMADO AD CAUSAM. Todas as empresas envolvidas na excursão com um fim específico tem legitimidade para serem demandadas em juízo pelos seus usuários/consumidores, ainda que como prestadoras de serviços se relacionem entre si por meio de contratos distintos. As pessoas que viajam em excursão contratada são consumidoras de serviços; estando amparadas pelo Código de Defesa do Consumidor. As agências do turismo são diretamente responsáveis pelos atos de seus prepostos ou de terceiros por elas contratadas ou autorizados, ainda que como autônomos.

(Ap. Civ. N. 273.210-3, Comarca de Belo Horizonte, 4. Câmara Civil do TAMG, rel. Juiz Avilmar de Ávila)

EMENTA: PACOTE TURÍSTICO - VENDA POR AGÊNCIA DE TURISMO - EXECUÇÃO DOS SERVIÇOS POR OUTRA EMPRESA - DANOS - RESPONSABILIDADE SOLIDÁRIA. De acordo com as normas do Código de Defesa do Consumidor, existe a solidariedade passiva de todos os que, de alguma forma, participam da cadeia econômica de produção, circulação e distribuição dos produtos ou de prestação de serviços. A agência de turismo responsável pela venda de pacote turístico responde pelos danos decorrentes da má qualidade dos serviços, ainda que estes tenham sido prestados por outra empresa, já que, entre ambas, prevalece a responsabilidade solidária. 
(Ap. Civ. n. 292.342-2 1., Câmara Civil do TAMG, rel. Juiz Silas Vieira)

A empresa que se encarrega da venda de pacote turístico e o divulga é a parte legítima na ação de reparação de danos, quando a avença não foi cumprida integralmente pela empresa que executou os serviços. Existe solidariedade entre elas, que decorre do Código de Defesa do Consumidor - artigos 7. E 25, parágrafo 1 .,ambos devendo responder civilmente (dispositivos citados e mais 159 do Código Civil). Uma empresa atua em função da outra.

(Ap. Civ. N. 009142720, ITAPR, rel. Juiz Antônio Martelozzo, Curitiba, j. 11/12/96, Ac. 5.615, pub. em 21/02/97).

b) Atraso no vôo / Indenização / Responsabilidade Solidária / Agencia de Viagem /

\section{Companhia Aérea}

EMENTA: DANO MORAL. VIAGEM FRUSTRADA. SOLIDARIEDADE DA AGENCIA TURÍSTICA. FALHA DO SERVIÇO. DEVER DE REPARAÇÃO. ARBITRAMENTO DO VALOR. CRITÉRIO:

I- $\quad$ A agência de viagens responde solidariamente com a empresa aérea pelos atrasos de vôos, os quais são falhas do serviço. A solidariedade decorre da norma expressa contida no artigo 25, par.1. da Lei 8.078(CDC).

II- $\quad$ O dano moral indenizável não é fruto do inadimplemento do contrato, mas do desconforto, da angústia e da fadiga sofridos pelos viajantes frustrados.

III- $\quad$ A fixação da indenização por dano imaterial é feita por arbitramento judicial (artigo 1.553 CC), adotando-se os parâmetros do artigo 84 da Lei 4.117, ainda que revogada pelo DL 236/67, que é o melhor sinaliza ao juiz para o estabelecimento do valor da reparação. A razoabilidade, por seu turno, advém da aplicação analógica do artigo 1.059, “caput”, parte final do CC.

IV- Apelação da fornecedora não promovida. Recurso adesivo dos consumidores provido em parte para aumentar a indenização.

(Ap. Civ. n. 1999.001.2841, $17^{a}$ Câmara Cível do TJRJ, Rel. Bernardo Garcez, Rio de Janeiro, J. 07/04/99, Unânime) 


\section{c) Responsabilidade Solidária / Agência de Viagem / Companhia Aérea / Operadora}

AGÊNCIA DE VIAGEM - RESERVA EM VÔO INEXISTENTE- REPARAÇÃO DE DANOS - DANO MORAL. Agência de viagem. Fazer reserva em vôo inexistente, causando transtornos ao consumidor. Reparação devida. A agência de viagem responde objetivamente pelos danos causados ao consumidor, sobretudo quando faz reserva em vôo inexistente a causa seríssimos transtornos ao passageiro, que se surpreende ao tomar conhecimento no aeroporto de que não existe nenhuma reserva em seu nome e que a reserva anotada no bilhete de sua passagem aérea é apenas fictícia. (ACÓRDÃO N.126.061/Juizado Especial DF, rel. Juiz Roberval Cassemiro Belinati/ Decisão: Recurso conhecido. Negou-se provimento. Unânime.

(ACJ 1999011057036-0, TRJE, publ. em 24/05/00, DJ 3, p. 62)

\section{d) Categoria de Hotel Inferior / Pluralidade de Fornecedores / Responsabilidade Solidária / Agência De Viagem / Contrato}

“PACOTE TURÍSTICO. MÁ PRESTAÇÃO DOS SERVIÇOS DE TRANSPORTE E HOTELARIA. Indenização aos usuários. A má ou inadequada prestação dos serviços em viagem de turismo, referentes a transporte e hotelaria, gera à empresa que os oferece o dever de indenizar. Valor da indenização. Há que ser razoável, quer para os usuários, quer para a empresa de turismo. Hipótese discutida. Caso em que o valor de $100 \%$ sobre o custo da viagem se apresenta razoável. Apelação dos autores e recurso adesivo da ré; desprovimento de ambos os recursos”.

(Ap.Civ. n. 597060268, TJRS, 6. Câm. Cív., re. Des. Osvaldo Stefanello, j 22/04/98)

\section{e) Furto / Alteração de Hotel / Responsabilidade / Agência de Viagem}

PACOTE NO EXTERIOR. ALTERAÇÃO DO HOTEL. FURTO DE MALA NO APARTAMENTO. Pedida indenização material contra a agência vendedora e operadora. Agências alegaram intermediação e culpa extracontratual, de responsabilidade do hotel. Consideradas responsáveis pela tranqüilidade e proteção da viagem. Condenação no valor pretendido.

(Ap.Civ. n. 2250/94, TJRJ, 3.Câm Cív, 1994) 


\section{f) “Folder" / Rescisão / Publicidade Enganosa /Hotel / Pacotes Turísticos-} Publicidade Enganosa - Rescisão Contratual Justificada - Sentença confirmada.

O consumidor de "pacote turístico" tem o direito de exigir do hotel previsto para a hospedagem os equipamentos de conforto e lazer previstos no folder promocional que lhe foi entregue quando do contrato. Verificando-se a ocorrência de publicidade enganosa, é direito do consumidor optar por outra acomodação, rescindindo unilateralmente o contrato, por justa causa, não podendo ser responsabilizado pelo pagamento de serviço não utilizado.

(Ap. Civil 31/98 - Juizado Especial de Alagoas - v. unânime - rel. /Dra. Ana Florinda Dantas, DO 10.09.98)

\section{g) Cancelamento /Pacote de Turismo/ Responsabilidade Solidária/ Agencia de} Viagens / Operadora de Turismo

CONTRATO DE TURISMO - RESCISÃO - PACOTE DE VIAGEM, CANCELAMENTO PARCELAS PAGAS, DEVOLUÇÃO - DANO MORAL. Contrato de Turismo. Pacote de viagem cancelado. Inadimplência da empresa de turismo. Responsabilidade solidária entre a agência de turismo contratada e a operadora de turismo. Indenização devida. Dano moral constatado em face da suspensão da viagem. Restituição de parcela paga. Litisconsórcio facultativo. I- O descumprimento contratual, decorrente da suspensão da viagem turística, acarreta para os responsáveis a obrigação de indenizar por dano moral, em face da frustração do lazer e do sofrimento que o fato ocasiona. No caso, a contratante sofreu forte abalo psicológico porque até à véspera da viagem foi enganada pelos agenciadores, com a promessa de que estava quase tudo acertado para a viagem foi enganada pelos agenciadores, com a promessa de que estava quase tudo acertado para a viagem, quando, na realidade, o pacote turístico não poderia ser cumprido por causa da inadimplência por dano moral, caberá aos responsáveis a restituição por dano mora, caberá aos responsáveis a restituição das parcelas recebidas para o pagamento do pacote turístico devidamente corrigidos. II - Respondem solidariamente a agência de turismo e a operadora de turismo pelos danos decorrentes do descumprimento do contrato, nos termos do artigo 896 e seguintes do Código Civil, bem como no artigo 34 do Código de Proteção e Defesa do Consumidor (Lei n. 8.074, de 11/09/90, verbis: “O fornecedor do produto ou serviço é solidariamente responsável pelos atos de seus prepostos ou representantes 
autônomos". Aplica-se ainda, o disposto no artigo 25,III, do CPDC: "Se o fornecedor de produtos ou serviços recusar cumprimento à oferta, apresentação ou publicidade, o consumidor poderá, alternativamente e à sua livre escolha:- rescindir o contrato, com direito à restituição de quantia eventualmente antecipada, monetariamente atualizada, $e$ perdas e danos”. Existe, portanto solidariedade passiva quando os gerenciadores $e$ operadores se unem, por vontade para a consecução de um objetivo comum, no sentido de fornecer o pacote turístico. III- Em face da solidariedade passiva existente entre a agência de turismo e a operadora de turismo, o credor, nos termos do artigo 904 do Código Civil, tem direito a exigir e receber de uma ou outra a dívida comum. Poderá, em conseqüência, escolher a que quiser para figurar no pólo passivo da demanda, eis que se trata aqui de hipótese de litisconsórcio facultativo, que poderá ser constituído por sua vontade conforme o artigo 46, inciso II, do Código de Processo Civil. Assim sendo, ö credor, na obrigação solidária passiva, está autorizado a acionar qualquer um dos co-devedores, à sua escolha, sem que com isso fique impedido de acionar os outros, caso o demandado, por exemplo, não apresente condições econômicas para saldar o débito, seja incapaz ou não seja encontrado.

(RT, 104:251 / Acordão n. 17.640, Rel. Juiz Roberval Casemiro Belinati, Decisão: Resultado final: Recurso conhecido. Negou-se provimento. Unânime/Juizado Especial DF/ (ACJ 808/99, TRJE, publ. em 20/09/09,DJ 3, p.28).

\section{h) Culpa Concorrente / Consumidor -Vítima / Agência de Viagem}

CÓDIGO DE DEFESA DO CONSUMIDOR. RESPONSABILIDADE DO FORNECEDOR. CULPA CONCORRENTE DA VÍTIMA. HOTEL. PISCINA. AGÊNCIA DE VIAGENS. Responsabilidade do hotel, que não sinaliza convenientemente a profundidade da piscina, de acesso livre aos hóspedes. Artigo 14 do CDC. A culpa concorrente da vítima permite a redução da condenação imposta ao fornecedor. Artigo 12, parágrafo 2.,III, do CDC. Agência de viagens responde pelo dano pessoal que decorreu do mau serviço do hotel contratado por ela para a hospedagem durante o pacote de turismo. Recursos conhecidos e providos em parte.

(4 . Turma, Resp.. n. 287849, STJ, rel. Min. Ruy Rosado de Aguiar, j. 17/04/01, m. v.) *inteiro teor de decisão disponível. 


\section{i) Diversas}

HOTEL - ACIDENTE EM ESCADA- DEVER DE INDENIZAR

“A usuária acidentou-se em queda na escada do hotel, por ocasião de uma feira, sofrendo traumatismos que a afastaram de seu ofício profissional Constatados defeitos na escada, cabendo ao hotel, a responsabilidade pelos danos sofridos”.

(TJRS - 7aCC; Ap. Cível 597144641, Rel. Des. José Carlos Teixeira Giorgis; 22.04.98)

\section{PARQUE AQUÁTICO- RESPONSABILIDADE CIVI L- ACIDENTE EM BRINQUEDO INFANTIL- INOBSERVÂNCIA DE DEVER DE VIGILÂNCIA.}

“Age com culpa e responde pelos danos causados pelo acidente, clube social que ignora as recomendações do fabricante do brinquedo instalado no parque aquático e permite que os usuários dele se utilizem sem a indispensável e eficaz vigilância, que era de sua inteira responsabilidade. O menor usuário acidentou-se na utilização do brinquedo sofrendo fratura no maxilar superior, necessitando fazer o reimplante de um dente, juntamente com uma cirurgia plástica”.

(TJRS-10 a CC; Apelação Cível 70001452184- Caxias do Sul; Rel. Des. Paulo Antônio Kretezmann- 19.04.2001)

\section{RESPONSABILIDADE CIVIL. MORTE DE TURISTA EM ASSALTO OCORRIDO EM ÔNIBUS, PERPETRADO POR OUTROS PASSAGEIROS.}

“A transportadora deve responder pele reparação da morte de passageiro de ônibus provocada por disparo de arma de fogo, em assalto praticado por outros passageiros, durante o transcurso de viagem de turismo. Não se caracteriza o caso fortuito, a beneficiar a transportadora, não se concorrem o elemento objetivo, qual seja a inevitabilidade do evento e o elemento subjetivo, isto é, a ausência de culpa da mesma, assim, restando refutada a alegação de ilegitimidade passiva, a cobertura dos danos pessoais, por apólice de seguro, não abrange os danos morais(voto vencido), peliculares do caso a recomendar que a pensão, a favor dos filhos menores da vítima, sejam estendidas até que completem 25 anos de idade. Reparação por dano moral bem arbitrada, inclusive, por não desmerecida afeição entre a vítima, sua mulher e os filhos menores do casal, a correção monetária do valor a ser reembolsado por seguradora denunciada a lide, deve iniciar a data do evento, não na contratação do seguro, pela locupletamento indevido da transportadora segurada, improcedente a denunciação da lide 
a outra seguradora, porque o seguro obrigatório realizado, opor disposição regulamentar, não cobre o sinistro, a verba honorária arbitrada deve ser mantida, uma vez obedecendo os parâmetros legais e resguardando a dignidade profissional”.

(Tribunal de Alçada do RS; 3 a CC, Rel. Léo Lima; APC 195103460; 04.10.85)

RESPONSABILIDADE CIVIL. EMPRESA DE TURISMO E TRANSPORTE. INDENIZAÇÃO. CÓDIGO DE DEFESA DO CONSUMIDOR

“Ônibus de turismo. Lesões sofridas por passageiros. Existe a culpa contratual, com aplicação da teoria do risco administrativo. Código de Defesa do Consumidor, art. 14 “caput”.

(Tribunal de Alçada do RJ, 2ª̂amara. Rel. Marly Macedônio, 29.02.96, Ap. Civil 9494/95)

\section{2. - CASOS REAIS - DEPOIMENTOS - COMENTÁRIOS}

Foram selecionados alguns casos reais e curiosos, reclamados e publicados na revista mensal "VIAGEM E TURISMO", da Editora Abril S.A, especializada no segmento turístico, na coluna Férias Frustradas, onde turistas/hóspedes/consumidores deixaram consignados suas queixas quanto à prestação de serviços na área de turismo e hospitalidade, para serem comentados:

\section{a) O CASO DAS BARATAS NO PACOTE 5 ESTRELAS}

Fonte: Viagem e Turismo, Setembro de 1998, Ano 4 nº 9, Edição 35

\section{A acusação}

“Após longo período de trabalho, eu e minha família decidimos passar o último Reveillon em grande estilo no Hotel Nas Rocas Island, de Búzios. Segundo o Sandy’s Representações, que nos vendeu o pacote, tratava-se de um estabelecimento de cinco estrelas, com todas as vantagens que se poderia esperar de um hotel dessa categoria. Mas, 
que decepção! Pagamos nada menos do que R $\$ 6.564,00$ para ficar num hotel totalmente abandonado, com baratas e aranhas pelo caminho, cortina de plástico rasgada no banheiro e poucos funcionários para o atendimento. Diante disso, reclamamos à agência que nos vendeu o pacote a devolução de metade do valor pago, já que no nosso entender houve uma propaganda enganosa. Um mês depois, informaram-nos que nada seria devolvido. Até quando seremos prejudicados por pessoas que só querem levar vantagens? Antonio Péricles Barbosa, Campinas SP.

\section{A defesa}

Com relação à reclamação do hóspede, temos a declarar: a) ele e sua família, num total de quatro pessoas, compraram um pacote de sete noites, que incluía vôo direto de SPBúzios-SP, pensão completa, ceia de Reveillon com champanhe, passeio de escuna e acesso gratuito a todos os equipamentos do hotel (caiaques, windsurfe, tênis, mesa de sinuca e campo de golfe, entre outros).b) a suíte 64, onde ficaram hospedados, possui blindex no banheiro. c) o hotel fica em uma ilha, cujo tratamento do meio ambiente é realizado diariamente pela empresa Rei Astral, com respeito às normas ambientais e pessoal treinado. d) durante o Reveillon, nosso índice de ocupação foi de $100 \%$ e nossa festa é reconhecida como a melhor de Búzios. Miguel Miranda, Hotel Nas Rocas Island.

\section{O veredito}

O hóspede tem direito a pedir uma compensação pelo serviço que ficou abaixo da sua expectativa, amparado no artigo 20 do Código de Defesa do Consumidor. Caso fique caracterizada a chamada prestação defeituosa de serviço, a lei prevê a reexecução do serviço, a rescisão do contrato com a devolução corrigida das importâncias pagas ou o abatimento no preço cobrado. Na falta de um acordo, o sr. Antônio Péricles Barbosa pode recorrer ao Procon ou ao Juizado Especial Cível (de pequenas causas), sem necessidade de advogado se o valor da causa for inferior a 20 salários mínimos, que hoje equivalem a R\$ 2600,00 ou com a assistência obrigatória de um advogado caso sua reivindicação esteja entre 20 e 40 salários mínimos”.

\section{b) SONHO DE JERICOACOARA TERMINA COM PESADELO.}


Diversos

\section{A queixa}

"Eu e minha filha esperamos ansiosamente a chegada das férias para, enfim, conhecer Fortaleza e, claro, Jericoacoara. Mas a viagem virou um pesadelo, assim que compramos um pacote do Shopping Turismo, em Fortaleza, que incluía transporte a Jericoacoara e hospedagem na Pousada dos Coqueiros. Para começar, a Van da agência atrasou uma hora e meia. Depois, o quarto da pousada não tinha janela: só um buraco no alto da parede, por onde entrava toda a fumaça da cozinha, que ficava bem ao lado. $\mathrm{O}$ banheiro era sujo (havia tufos de cabelos grudados no ralo) e sem lâmpada. À noite, minha filha achou três baratas gigantes no banheiro. Decidimos não ficar mais ali e pedimos para voltar a Fortaleza no dia seguinte. Tentamos tomar um banho antes de deixar a pousada, mas não havia água. Domingos, o dono da Shopping Turismo e da pousada, estava lá e minha filha foi reclamar para ele. Ele se revoltou: “Agora quem não quer mais vocês aqui sou eu, e só tiro vocês daqui se pedirem desculpas”, gritou. Apavoradas, resolvemos nos desculpar. Será que empresas como a Shopping Turismo continuarão manchando o Turismo no Brasil? Marli Mello Carlini, São Paulo, SP.

\section{A defesa.}

A cliente esperou, por algum tempo, a Van passar no seu hotel de Fortaleza porque um dos viajantes nos atrasou, entrando no grupo de última hora. Em Jericoacoara, ela ficou nas melhores acomodações da Pousada do Coqueiro. Infelizmente, na vila costuma faltar energia, impossibilitando o fornecimento de água e luz. Como a Dona Marli não parava de reclamar eu sugeri que ela trocasse de pousada. Sobre as três baratas, peço desculpas, lembrando que não as crio. Se a cliente não entendeu minhas atitudes, que me desculpe. Domingos Marques Vieira, dono do Shopping Turismo.

\section{A conclusão}

Apesar de belíssima, Jericoacoara continua sendo uma aldeia de pescadores com estrutura precária, onde é normal faltar água e luz. Mas isso não impede que algumas pousadas locais sejam charmosas e até confortáveis - embora muitas delas, incluindo a pousada dos Coqueiros, sejam mesmo muito simples. O segredo para curtir essa praia do Ceará é ter uma idéia real das condições de hospedagem, para não se decepcionar. A 
Shopping Turismo pode trabalhar com uma pousada rústica, mas não deve esconder esse fato dos clientes”.

\section{c) BARATA VOADORA NO HOTEL}

Fonte: Viagem e Turismo, junho de 2001, ano 7, nº 6, edição 68.

“Fiz uma reserva no Hotel Vivenda Penedo, no Rio de Janeiro, para os dias 23 a 28 de fevereiro. Como sinal, no ato da reserva, paguei metade do valor acertado, que era de R\$ 970,00. logo na chegada, encontrei no quarto uma lagartixa e uma barata voadora, que subiu pela roupa de minha mãe. Quando reclamei com o proprietário, por telefone, ele afirmou que essas ocorrências eram normais por lá, assim como na casa dele. Resolvi, então deixar o hotel no dia seguinte. Antes de ir embora, ainda tentei pedir de volta os R\$ 500 que paguei de sinal, já que havia passado apenas uma noite no hotel, mas o proprietário não concordou. Ou seja, paguei R\$ 500 por uma noite mal dormida e estava de volta ao Rio de Janeiro em menos de 24 horas. Teresa França, Rio de Janeiro, RJ.

O proprietário do Hotel Vivenda Penedo, Carlos Octavio Xavier, afirma que seres como lagartixa e mariposas são encontrados em todos os lugares onde haja natureza abundante, como é o caso da cidade de Penedo. Para manter os bichos indesejáveis longe dos hospedes, as janelas de todos os chalés são equipadas com telas protetoras. Xavier lembra que Teresa foi dispensada do pagamento do restaurante do pacote comprado, mesmo que isso significasse prejuízo para o hotel, já que foi impossível alugar o chalé para outras pessoas pelo restante do feriado de Carnaval. A leitora precipitou-se em antecipar a volta para o Rio de Janeiro. Se resolvesse ficar no hotel, teria direito de trocar de quarto e pedir reembolso de parte do valor acertado. Como foi embora, rompeu o contrato firmado e não pode pedir o dinheiro do sinal de volta”.

\section{d) SANGUE NO TRAVESSEIRO}

Fonte: Viagem e Turismo, junho de 2001, ano 7, nº 6, edição 68. 
“No início deste ano, reservei um chalé para passar o Carnaval com minha família no Itamanbuca Pousada \& Camping, em Ubatuba, litoral norte de São Paulo. Deixamos São Paulo no sábado as 9 e meia da manhã e, por causa do trânsito, só chegamos às 5 da tarde, cansados e famintos. O primeiro contato com a recepção foi desastroso. Levei quase uma hora para ser atendido e ouvir da funcionária: "Para encontrar seu chalé, volte pelo mesmo caminho". Quando finalmente encontrei o “caminho", mesmo sem a ajuda de um mensageiro, tive uma surpresa desagradável. O banheiro estava sujo, havia teias de aranha embaixo da cama e a fronha do travesseiro estava manchada de sangue. Os lanches eram preparados por um funcionário sem luvas - vimos até um deles limpando seu suor com a mesma mão com que preparava os sanduíches. Pagamos R\$ 850 por um serviço deplorável. Procurei o gerente duas vezes durante a nossa estada, mas ele não apareceu. Agüentamos até onde deu e depois viemos embora. Márcia Ribeiro, São Paulo, SP.

O gerente da pousada, Denis Dreux Junior, afirma que não foi encontrado pela cliente porque ela o procurou às 22h30, meia hora após o final de seu expediente. Ela ressalta que, na sua ausência, as reclamações poderiam ter sido encaminhadas à recepção ou à governança, já que todos os funcionários da pousada teriam autonomia para encontrar uma solução pra os problemas citados. Dreux Junior desculpa-se por não ter atendido as expectativas de Márcia e oferece um final de semana de hospedagem grátis como compensação. Embora a atitude do gerente demonstre boa vontade em corrigir os erros no atendimento, talvez Márcia não queira voltar à pousada que a decepcionou. Neste caso, ela pode pedir o ressarcimento de parte do dinheiro pago enviando uma carta ao gerente. Um modelo desse tipo de carta está disponível na Internet, no site www.idec.org.br”.

\section{COMENTÁRIOS DA AUTORA - CASOS: A,B,C E D:}

Trata-se de má prestação dos serviços - inadequados ou insuficientes na sua oferta.

De acordo com o Código de Defesa do Consumidor, os hóspedes/consumidores tem direito ao serviço a ser prestado, visando a higiene, a saúde e a segurança. 
O Artigo 20 do CDC dispõe que quando o serviço é defeituoso ou inadequado, como nos referidos casos, pode o hóspede/consumidor á sua escolha, pedir a restituição imediata das quantias pagas.

Pode-se notar que as alegações dos fornecedores nos casos apresentados acima não convenceram. É bom frisar que o risco do negócio são deles e não dos hóspedes/consumidores, podendo inclusive, serem responsabilizados por danos morais.

\section{e) VALE O QUE ESTÁ ESCRITO.}

Fonte: Viagem e Turismo, agosto de 2002, ano 8, nº 8, edição 82.

“No site do hotel, havia um preço. Pelo telefone, outro valor foi negociado. Como é que fica?”

Minha esposa e eu estávamos pensando em comemorar nosso aniversário de casamento, entre 20 e 23 de junho, na Praia do Forte, Bahia. Fizemos uma busca na internet e deparamos com o site do Hotel Porto Zarpa. O que nos atraiu, além da beleza do hotel, foram as tarifas: $\mathrm{R} \$ 135,00$ o quarto duplo, com 10\% de taxa de serviços não inclusos. Entrei em contato com hotel e negociamos o valor para $\mathrm{R} \$ 108,00$ a diária, o que daria um total de $\mathrm{R} \$ 324,00$ pelos três dias. A funcionária que me atendeu combinou enviar um e-mail como o que fora acordado. Depois de esperar o retorno, que não houve, entramos em contato novamente e falamos como o proprietário do hotel. Ele nos informou que, por se tratar de período de São João, a diária seria de R\$155,00. Argumentei que havíamos combinado outro valor e ele ficou de nos ligar em quatro dias. Numa nova ligação fui informado que seria feito um preço especial para os três dias: em vez de $\mathrm{R} \$ 700,00$, R\$600,00. Ou seja, da diária de $\mathrm{R} \$ 108,00$, inicialmente acertada, eu deveria pagar R \$200,00, com desconto. Sinto-me explorado por esse hotel - cujos múltiplos preços só aumentam, à medida que conversamos”. Rafael Visconti, São Paulo, SP.

Rafael viu na página do hotel um preço, negociou outro e não levou nenhum. Parece um problema de comunicação, mas na verdade envolve outra questão: os preços publicados na internet nem sempre funcionam na prática. No caso do Porto Zarpa, o valor que consta no site para a alta temporada é $\mathrm{R} \$ 155,00$ mais $10 \%$ de taxa para o quarto duplo 
(R\$135,00 é a diária na baixa temporada). Multiplicando por três, dá R\$511,50. Entretanto, no final da negociação, ofereceram um pacote de $\mathrm{R} \$ 600,00$. O proprietário do Porto Zarpellon, explicou a Viagem que o preço do site está correto, mas que realmente em feriados e datas especiais os hotéis costumam criar pacotes com valor diferenciado. Estaria tudo certo, não fosse o fato de tal preço não estar publicado na internet. Maria Inês Dolci, advogada do Consumidor, diz que, segundo o Código de Defesa do Consumidor, o que está escrito no site tem de ser cumprido, e que a mudança dos valores também deve constar lá. Caso contrário isso caracteriza propaganda enganosa. Em resumo: entre os R\$108,00 combinados verbalmente e os $\mathrm{R} \$ 600,00$ do pacote especial, valem, para todos os efeitos, os R\$155,00 que estão anunciados”.

\section{f) NO SITE DA INTERNET, A DIÁRIA ERA BARATINHA. MAS...}

Fonte: Viagem e Turismo, março de 2000, ano 6, n 3, edição 53.

\section{A queixa.}

"No final do ano passado, viajei com uma amiga para a Itália. Reservamos o hotel Piazza de Spagna, em Roma, por um site na internet, que contava tudo sobre o hotel, incluindo o preço da diária: 350000 liras, até o dia 30 de outubro, e 240000 a partir de $1^{\circ}$ de novembro. Fizemos então as reservas para o período de 1 a 6 de novembro por e-mail e recebermos como resposta um fax equivocado, confirmando nossa reserva para estada de 25 a 29 de outubro com diárias de 350000 liras. Imediatamente contatei o hotel, informando a data certa. No mesmo dia, recebemos um e-mail do senhor Roberto Mariani corrigindo os dias da reserva e confirmando a tarifa de 240000 liras. Por precaução, não enviamos o número do cartão de crédito por e-mail, preferindo faze-lo por fax. Mas para a nossa surpresa, ao sairmos do hotel, o funcionário nos apresentou uma conta calculada sobre a diária bem mais alta, alegando que o valor acertado nunca existira e que ele não se responsabilizava pelo que era divulgado na internet. Sem outra saída, pagamos a conta e voltamos ao Brasil. Daqui, tentamos reaver as 550000 liras excedentes que pagamos temos os comprovantes - mas, o hotel se recusa a nos reembolsar. Suely Abud Souza, por e-mail.

\section{A defesa.}


Houve um mal-entendido entre o sr. Mariani e a sra. Souza, porque, infelizmente, não temos o controle sobre o que é publicado na site do hotel na internet. Sinto muito pelo ocorrido, pois sei que a sra. Souza está certa. Mas o sr. Mariani já não trabalha mais aqui e não posso assumir seus erros. Posso apenas desculpar-me e oferecer um bônus de hospedagem para um final de semana quando a sr. Souza e sua amiga retornarem a Roma. Elizabetta Giocondi, gerente da Piazza di Spagna.

\section{A conclusão.}

O hotel é, sim, responsável pelo que divulga e, também, pelos compromissos assumidos por seus ex-funcionários. Se a leitora não puder usar o bônus oferecido pelo hotel- afinal, não se vai a Roma assim, para um simples fim de semana- , ela deve insistir na devolução da quantia paga a mais”.

\section{g) POUSADA VIRA CASO DE POLÍCIA EM MONTE VERDE.}

Fonte: Viagem e Turismo, Setembro de 1999, ano 5, nº 9, edição 47

\section{A queixa:}

“Eu e minha família fomos vítimas da Pousada Al Di Lá, em Monte Verde, Minas Gerais. Através de um anúncio de revista, liguei para o proprietário, que me descreveu o lugar como sendo de "ampla área totalmente gramada, com salão de jogos, playground, quadra de tênis, quadra poliesportiva e sala de refeições”. Disse a ele que nosso filho era portador de alergia respiratória e que, por isso, não podia ter contato com mofo. Fui tranqüilizado pois, segundo o proprietário, os chalés eram novos. Mas, quando chegamos à pousada, ficamos chocados. O gramado era um matagal. A piscina estava imunda. A sala de refeições resumia-se a uma geladeira velha e um fogão encardido. A quadra poliesportiva estava totalmente deteriorada (é só ver a foto que estamos mandando). O pior : o chalé exalava forte cheiro de mofo. Claro, procurei outra pousada para ficar. Por duas vezes tentei um acordo para reaver o que paguei na reserva. E por duas vezes o proprietário se recusou a devolver meu dinheiro, alegando que ninguém jamais havia reclamado de suas tão deprimentes instalações. Carlos Quadros, Santo André, SP.

\section{A defesa.}


A reclamação revela má-fé e tendenciosidade. Nosso estabelecimento nunca foi apresentado como um hotel-fazenda, com ampla e sofisticada estrutura. Anunciamos o que oferecemos: lareira, piscina, café da manha, quadra de esportes, playground e uma sala de jogos. Temos chalés rústicos, mas bastante arejados. E o Sr. Quadros prestou queixa na delegacia local, porém não compareceu a audiência com o juiz. Maria Lúcia Forlenza, Al Di Lá Chalés, Monte Verde - Minas Gerais.

\section{A conclusão.}

Aparentemente, há exageros de ambas as partes. O hóspede descreve a pousada como sendo a ante-sala do inferno. Já a pousada, como se vê nas fotos, não é nenhum primor: a foto do leitor mostra que a quadra esportiva não estava em boas condições, ao menos na ocasião, como se vê na outro foto, enviada pela pousada e datada de 7 de fevereiro”.

\section{h) TUDO INCLUÍDO MESMO?}

Fonte: Viagem e Turismo, maio de 2002, ano 8, n5, edição 79.

“Uma leitora se hospeda num hotel all inclusive - e tem uma surpresa que não estava incluída.

Eu, meu marido e alguns amigos, passamos o Reveillon no Barceló Oásis Praia das Fontes, um resort em Beberibe, Ceará, com sistema all inclusive - ou seja, em que tudo está incluído no preço da diária. Após ganharmos as pulseiras para identificação dos hóspedes, fomos informados, no restaurante, que só tínhamos direito a bebidas nacionais. Procurei a agência e argumentei que a propaganda do hotel e em jornais e revistas não informavam essa limitação e que as bebidas que nos serviram eram de péssima qualidade. Depois de muita conversa, trocaram nossas pulseiras brancas por lilases. Essas pulseiras, concedidas a pessoas consideradas vips, davam direito a realmente tudo. Perguntei se havia diferença de preço pago por quem portava a pulseira lilás e me disseram que não. Acho esse ato discriminatório e considero a falta de informação nos anúncios uma atitude de máfé. Maria Elena Adell Roso, São Paulo, SP.

O sistema all inclusive é sucesso pelo mundo e cada rede de hotéis tem seu procedimento em relação a ele. Mas, segundo Maria Inês Dolci, advogada da Proteste - 
Associação de Defesa do Consumidor, a limitação ao consumo de bebidas nacionais deveria estar clara nos anúncios, pois o "fornecedor tem obrigação pré-contratual de manter a sua oferta nos termos em que foi veiculada”. Em defesa do hotel, seu diretor, Javier Cordero, alega que todas as informações sobre a política de all inclusive estão no site, “o que prova a ausência de publicidade enganosa”. A advogada recomenda que o hotel informe a existência do site (ou envie cópia em papel a quem não tem acesso à internet), para que o consumidor tome o conhecimento dessa política antes da viagem. No caso das pulseiras, ela é taxativa: “ Se o cliente não for informado, isso pode representar discriminação”.

\section{i) A REGRA É CLARA.}

Fonte: Fonte: Viagem e Turismo, junho de 2003, ano 9, nº6, edição 92

“Comprei um pacote de viagem para o sul do país, mas, ao chegar à pousada, descobrimos que seus quartos não correspondiam às fotos mostradas na internet. Por isso, resolvi me hospedar em outro hotel, pelo qual paguei à parte. Posso ser reembolsada, já que não utilizei os serviços da pousada? Tânia Neves Adriano, Uberaba, MG.

Sim, Tânia, o cliente pode ser reembolsado por um pagamento antecipado se descobrir que o local de hospedagem não corresponde ao que lhe foi oferecido. Pouco importa se ele tomou conhecimento das acomodações por folheto, internet ou descrição feita pelo vendedor. Se não conseguir entrar em acordo com a pousada, então recorra ao Judiciário. A alegação será a de que as acomodações não correspondiam às imagens da internet. Mas é preciso juntar cópias impressas das imagens. A pousada deverá provar que as instalações são iguais àquela da net. Se isso não ocorrer, o estabelecimento terá de reembolsá-la.

\section{COMENTÁRIOS CASOS: E, F, G, H E I:}

O consumidor tem direito de exigir dos hotéis previstos para a hospedagem, os serviços e equipamentos de conforto e lazer, previstos nos folhetos (folders) promocionais, Internet ou descritos pelos prepostos ou vendedores. 
O hotel responde pela oferta veiculada, pois, consumidores podem ser impelidos por seu anúncio publicitário enganoso.

De acordo com o Artigo 35 do CDC, quando o serviço não é prestado como a oferta, o hóspede/consumidor tem a sua livre escolha, algumas opções como exigir o cumprimento forçado da viagem, aceitar outro pacote turístico ou período de hospedagem, rescindir o contrato e requerer os valores pagos, além da indenização por danos morais, por todo a frustração, transtorno, desilusão e aborrecimentos sofridos.

\section{j) CADÊ A MINHA PISCINA?}

Fonte: Viagem e Turismo, Fevereiro de 2002, Ano 8, nº 2, Edição 76

“O leitor fez a reserva no hotel. Mas, ao chegar lá, não encontrou o que esperava.”

No período de 16 a 21 de dezembro, estive no conceituado Costão do Santinho Resort, em Santa Catarina. Apesar de ter confirmado na minha reserva um apartamento com dois quartos e vista para os jardins, o que encontrei quando lá cheguei foi uma obra bem em frente a minha varanda. Pior: fui despertado todos os dias, às 7 h30, por uma betoneira e uma máquina de terraplanagem. Nas três vezes que tentei falar com o gerente fui informado de que o mesmo não estava e que posteriormente me ligaria no apartamento, o que não ocorreu. Também resolveram reformar a piscina olímpica no dia da minha chegada e durante os cinco dias em que lá estive fui obrigado a dividir uma minúscula piscina com algumas dezenas de crianças. Nada contra as crianças, mas pratico natação diariamente e esse foi um serviço oferecido que chamou minha atenção quando do fechamento do pacote. João Augusto Canal, São Paulo, SP.

Eis um caso em que a reclamação do cliente obteve resposta imediata do hotel. O Sr. João Augusto enviou sua queixa para a redação de Viagem e Turismo com cópia para a gerência do hotel. No mesmo dia entramos em contato com o Costão do Santinho e obtivemos a seguinte resposta da coordenadora de marketing, Priscila Tavares: "Lamentamos profundamente pelos aborrecimentos causados ao hóspede durante sua estadia conosco. Já entramos em contato com o sr. João Augusto Canal e oferecemos em caráter de cortesia um fim de semana neste resort, que poderá ser escolhido de março a 
novembro de 2002. Infelizmente as obras citadas pelo hóspede são de caráter urgente e inadiáveis, motivo pelo qual não pudemos interrompê-las. A piscina olímpica estava realmente fechada e o motivo era a obrigatoriedade de manutenção, com a finalidade de manter a segurança para nossos hóspedes”. A advogada Maria Inês Dolci lembra, no entanto, que, pelo artigo 20 do Código de Defesa do Consumidor, o resort deveria oferecer abatimento proporcional ao preço pago pelo pacote. "Se o estabelecimento sabia que esses serviços seriam executados, deveria ter colocado o hóspede em outra ala, além de informalo com antecedência das reformas. Assim, ele poderia ter a opção de adiar ou não sua estadia”.

\section{k) - NO HOTEL, A VISTA PARA O MAR DAVA PARA UM LIXÃO.}

Fonte: Viagem e Turismo, junho de 2000, ano 6, nº 6, edição 56

\section{A queixa.}

"Nunca fiquei em um hotel tão ruim como o Magna Praia, de Fortaleza. Para começar, fui obrigado a ficar num quarto dos fundos, quando o combinado era um apartamento de frente para o mar. Depois consegui trocar de quarto, mas a prometida vista para o mar era dividida com a vista para um lixão, que ficava bem ao lado do prédio do hotel. O banheiro tinha uma infiltração, pela qual escorria água do apartamento de cima. E, para completar, as toalhas eram rasgadas, não havia xampu nem pente no banheiro, o arcondicionado não tinha regulagem, a televisão veio sem controle remoto e a má vontade dos funcionários era de doer. Luís Assunção, Rio de Janeiro.

\section{A defesa.}

Não damos garantia de apartamento com vista para o mar. Ainda mais em alta temporada, quando o hotel fica lotado. Muitas vezes, a agência ou operadora promete o que não podemos cumprir; por falta de disponibilidade. O lixão a que o hóspede se refere é um terreno ao lado do hotel cujos donos se recusam a limpar e murar. Já entramos com uma denúncia na prefeitura de Fortaleza, mas nada aconteceu. O kit com sabonete e xampu é um serviço opcional - e não obrigatório- de um hotel três estrelas, como o nosso. Quanto às outras reclamações, elas seriam resolvidas se o cliente as fizesse durante sua estada no nosso hotel. Só assim poderíamos tê-lo atendido. Milena Barbosa, Gerente Geral. 


\section{A conclusão.}

O hotel tem razão ao dizer que seria mais fácil sanar os problemas durante a estada. Mas, o ideal mesmo seria que o hóspede não tivesse do que reclamar.

\section{l) UMA SEMANA SEM PISCINA NEM CAMA DE CASAL.}

Fonte: Viagem e Turismo, fevereiro de 1999, ano 5, n²2, edição 40

\section{A queixa.}

“Compramos um pacote da Visual Turismo para Fortaleza, através de uma agente de viagem. Escolhemos o hotel Praiano, com quatro estrelas e piscina, e pedimos um quarto com cama de casal. Tivemos, no entanto, uma série de transtornos, começando pelos vouchers que só conseguimos pegar dois dias antes do embarque, pois a agente estava viajando. Depois, voamos em poltronas separadas, a escala durou 2 horas e nenhum almoço foi servido a bordo. Mas o pior mesmo foi que nosso quarto "de casal” tinha três camas e todas de solteiro. E a piscina estava em reforma. Não fomos avisados de nada disso. Daí a nossa reclamação. Afinal, pagamos R\$ 1400 pelo pacote, R\$ 400 a mais do que em outros hotéis, só para ter mais conforto. Regiane e Roberto Camussi, São Paulo, SP.

\section{A defesa.}

Desde que recebemos a reclamação da leitora e nossa cliente, temos tentado resolver esta situação. Os vouchers, no entanto, estavam prontos muito antes da viagem, sendo a agente de viagem responsável pelo atraso. Os passageiros pagaram R\$ 1408 pelos dois pacotes porque o hotel Praiano é um quatro estrelas e não pelo fato de terem pedido um quarto com cama de casal - a mobília do quarto não altera o preço. Lamentamos, no entanto, o fato de o hotel não ter disponibilizado um quarto com cama de casal. Não pudemos interceder, já que os passageiros só nos informaram disso ao voltarem. Realmente, não sabíamos que a piscina estava em reforma. É função do hotel passar esta informação a todas as agências. Pedimos uma explicação do hotel Praiano, mas não obtivemos resposta”. Visual Turismo.

\section{A conclusão.}

É realmente desagradável pagar um pacote esperando encontrar uma coisa e se deparar com outra. Embora a Visual não tenha se omitido, o máximo que ela fez foi 
reenviar a reclamação ao hotel, sem obter, no entanto, a resposta. Como foi a agência que montou o pacote, ela é sim, responsável por problemas relativos ao hotel com o qual ela mesma resolveu trabalhar em parceria. Cabe, portanto, algum tipo de indenização ao casal. Num aspecto, porém, a resposta da agência procede: os reclamantes deveriam ter comunicado o fato enquanto ainda estavam em Fortaleza, de modo que ela pudesse resolver a situação a tempo”.

\section{COMENTÁRIOS - CASOS: J, K E L:}

Em primeiro lugar, os consumidores tiveram suas expectativas de férias ou descanso totalmente frustradas.

Não se pode querer que um casal em "lua de mel” passe seus dias prazerosos em camas separadas ou que se vá para um resort e encontre a piscina interditada.

É dever do fornecedor saber qual é a expectativa de seus clientes/consumidores e satisfaze-las.

Parece complexo, mas tem de ser tentado. Se o estabelecimento sabia que poderia não atender as expectativas de seus hóspedes (impedidos por estar em reformas, por exemplo), deveria informa-lo, dando-lhe a opção de adiar ou não a sua estadia.

Os consumidores podem pleitear, se quiserem, a reparação dos danos morais sofridos.

m) PAGOU O HOTEL DUAS VEZES PARA NÃO SER PRESO.

Fonte: Viagem e Turismo, fevereiro de 1999, ano 5, n²2, edição 40

\section{A queixa.}

“Comprei na agência Attualitá Turismo, em Campinas, três pacotes para uma semana em Nova York, da operadora Flot. Os bilhetes e vouchers só foram emitidos dois dias antes da viagem, já que a Flot alegava não estar conseguindo confirmar o hotel que pedi, o Milford Plaza. Eles tentaram até me fazer desistir da viagem, que eu havia pago com bastante antecedência. Finalmente, recebi os vouchers. Mas para um outro hotel, o Belvedere, para onde fomos levados assim que chegamos em Nova York . Três dias 
depois, no entanto, o gerente do Belvedere me chamou com a inacreditável notícia de que a conta do hotel, nada menos que US\$ 1600, havia sobrado para eu pagar! Segundo ele, a Flot tinha mandado sustar o pagamento feito à City Tours, agência com quem trabalham na cidade, e que a conta, sem dúvida, era minha. Não adiantou argumentar que eu já havia pago o hotel no Brasil: ou pagava novamente ou o gerente chamaria a polícia. A City Tours confirmou a situação. Segundo eles, a Flot afirmara que aquele era um hotel caro demais e quem havia feito a reserva era a agência Attualitá. Estranho, pois o voucher estava em nome da Flot. E o que eu tenho a ver com esse detalhe operacional entre agências? Fui obrigado a pagar em dinheiro - dólares que, aliás, me fizeram muita falta durante o resto da viagem. Já no Brasil, quando pedi o reembolso do valor integral, só me deram US\$ 1056, portanto US\$ 544 a menos. Isso é puro estelionato! Carlos R. de Souza, Campinas, SP.

\section{A defesa.}

Desde o começo, avisamos à Attualitá que não seria possível confirmar a reserva no hotel Milford, nem em outro similar, naquela época e por aquele preço. Sugerimos opções, como hotéis próximos ao aeroporto ou em Nova Jersey, mas a agência não aceitou. Ela buscou, então, por conta própria, outro hotel em Manhattan e pediu que assumíssemos a responsabilidade dessa reserva. Concordamos, contanto que a agência pagasse a diferença, já que esse hotel era mais caro. Quando informamos o valor da diferença, dias depois, a agência se negou a nos pagar, dizendo que tinha conhecimento de outro preço. Combinamos que a Attualitá acertaria o valor das diárias diretamente com o hotel. A culpa foi, portanto, da agência. E não nossa”. José Eduardo Barbosa, Flot Operadora Turística.

\section{A conclusão.}

A Flot alega ter agido corretamente e joga toda a culpa para a agência Attualitá. Na verdade, as duas são igualmente responsáveis - e divergências entre elas não podem recair sobre o passageiro que cumpriu sua parte no negócio, ou seja, pagou. Por isso, o leitor tem, sim, o direito ao ressarcimento das diárias que pagou em Nova York. E, se quiser, até uma reparação moral pelo constrangimento que passou lá. Para isso, pode recorrer ao Procon ou entrar com uma ação no Tribunal de Pequenas Causas, já que o valor não passou de R\$ 5200, o máximo para esse tipo de causa. Ah! E a ação pode ser movida contra as duas empresas ao mesmo tempo... Consultoria: Laércio G. Texeira, advogado especializado em defesa do consumidor e mediador. 


\section{n) LOTAÇÃO ESGOTADA.}

Fonte: Viagem e Turismo, janeiro de 2002, ano 8, nº 1, edição 75

“Eu e minha esposa nos hospedamos no Marriott Resort \& SPA - Costa do Sauípe. O hotel estava com a lotação máxima e demonstrou não ter estrutura para operar nessas condições. Pagamos previamente um jantar no restaurante asiático e qual não foi a nossa surpresa ao descobrir que não havia lugar nem fila de espera. Sugeriram que fossemos a outro restaurante no hotel. No dia seguinte, fomos almoçar em um restaurante que servia bufê e tinha a opção de serviço à la carte. Solicitamos o cardápio, mas quando íamos fazer o pedido fomos informados que iria demorar muito e que seria melhor optarmos pelo bufê. $\mathrm{Na}$ piscina, não havia cadeira nem guarda-sol. Após muita briga, arrumaram apenas a cadeira. Depois pedimos um suco de melancia. Só meia hora mais tarde é que nos disseram que a fruta havia acabado. Para finalizar, fomos acordados às 3h para fazer o check-out, sendo que o vôo era às 7h e deveríamos estar no aeroporto às 6h. Conclusão: chegamos ao aeroporto às 4h40. percebemos uma gritante preferência para servir estrangeiros. Talvez devido às gordas caixinhas. Celso Lima Júnior, São Paulo, SP.

Um complexo de hotéis cinco estrelas pode ter, eventualmente, problemas cinco estrelas. Steven Redkoles, gerente geral da Marriott, acha que observações como as de Celso são muito importantes para que melhorem os serviços. Redkoles afirma que sua equipe ficará contente em receber Celso novamente, para desfazer o mal- entendido, e o convida a passar um final de semana não Renaissance ou Marriott Costa do Sauípe - na faixa. As diárias incluem o tranfer aeroporto/hotel/aeroporto e café da manha. Caso Celso não fique satisfeito. Maria Inês Dolci, advogada do Idec, explica que o Código de Defesa do Consumidor (art.20, incs. I e II) é claro ao regular que o serviço que não atende de maneira completa a sua finalidade. O cliente ainda tem tempo de solicitar a devolução do valor pago pelo pacote ou abatimento do valor pago pelas diárias. As reclamações podem ser feitas no Juizado Especial Cível (para causas até 20 salários mínimos não é preciso advogado)".

\section{o) BRASILEIROS NO HOTEL RUIM, E EUROPEUS NO BOM. POR QUÊ?}


Férias frustradas.

\section{A queixa}

“Um dia antes de embarcar num vôo da Ibéria de Munique para São Paulo, com conexão em Madri, fui avisada de que haveria um atraso de várias horas na capital espanhola. Em vez de decolar no início da madrugada, o avião só poderia deixar Madri às 9 horas da manhã. Até aí, tudo bem, já que a companhia se encarregou de hospedar os passageiros em trânsito para São Paulo. O triste da história começou no balcão da Ibéria no aeroporto de Madri, quando percebi que, ao contrário dos passageiros de origem européia, eu e outros brasileiros fomos encaminhados a um hotel de padrão nitidamente inferior. Enquanto eles receberam vouchers para os confortáveis hotéis Barajas e Alameda, nós fomos dormir no hotel Osunas, que cheirava a mofo. Detalhe: atrás de mim na fila puderam ficar. Ou seja, tinha vaga lá. E , o pior de tudo: não pudemos jantar nem tomar café da manhã no Osunas, embora nosso voucher desse direito a essas refeições, porque o restaurante já estava fechado quando chegamos no hotel e só reabriu depois do nosso horário de saída. Fui discriminada por ser brasileira e isso é inadmissível. Annelise Fischer Thom, São Paulo, SP.

\section{A defesa}

A Ibéria trata seus passageiros com igualdade. Quando há necessidade de encaminhá-los a algum hotel em Madri, normalmente escolhemos os hotéis Barajas e Alameda, que ficam próximos do aeroporto. Naquele dia, porém, eles estavam lotados, e tivemos de recorrer ao Hotel Osunas, que é utilizado com freqüência pela Ibéria quando não há disponibilidade no Barajas e Alameda. Enviamos a reclamação da leitora ao Hotel Osunas. Miguel Mañe Portella, Diretor da Ibéria para o Brasil.

\section{A conclusão}

Diante de uma acusação grave, a de discriminar clientes brasileiros em favor dos europeus, a Ibéria limitou-se a dizer que trata a todos os passageiros com igualdade e que não havia vagas suficientes nos hotéis Barajas e Alameda. Mas não explica porque só os brasileiros foram alojados no Hotel Osunas, de padrão inferior. A leitora tem, sim, toda a razão de se indignar”. 


\section{p) AGENDA POR ÁGUA ABAIXO.}

Fonte: Viagem e Turismo, junho de 2003, ano 9, nº6, edição 92

“Ele precisava ir a Brasília para resolver seus compromissos. Só que cancelaram o vôo. O que fazer.

Comprei uma passagem aérea da Varig do trecho Belém- Brasília- Belém. Mas, três dias antes do embarque, fui informado de que o vôo fora cancelado. A viagem que iria fazer seria sem escalas. Partiria às 4 h05 e chegaria a Brasília à 6h20. Fiz essa escolha justamente porque tinha compromissos agendados muito cedo. A opção que me ofereceram foi a de um vôo com saída as 7h15, duas escalas e, com chegada prevista para as 11h15. Sendo assim, resolvi cancelar minha ida à cidade, pois não conseguiria participar de nenhuma das reuniões que tinha marcado havia semanas. Também tive de arcar com duas diárias no Hotel Nacional de Brasília, já que segundo o contrato, o cancelamento da reserva só seria permitido com 15 dias de antecedência. Fui prejudicado por uma decisão da Varig e gostaria de ser indenizado pelos danos e constrangimentos que isso me causou. Carlos Rodrigues Z. Junior, Belém, PA.

Os cancelamentos de vôo são, provavelmente, a maior pedra no sapato de viajantes e companhias aéreas. O caso de Carlos não será o último, mas pode se tomado como um bom exemplo: a empresa não pode transferir os riscos de sua atividade para o consumidor. Se ela oferece um serviço, mas cancela-o e tenta empurrar uma alternativa que não o satisfaz, então está praticando um ato ilícito. Isso está nos artigos 186 e 187 do novo Código Civil.

\section{Quem tem razão.}

A razão está com Carlos, que foi obrigado a adiar compromissos por motivos que não lhe diziam respeito. Mesmo que houvesse um único passageiro no vôo, a Varig deveria ter honrado o contrato.

\section{$O$ que fazer.}

Carlos pode recorrer ao Judiciário pedindo reparação dos danos econômicos (diária do hotel, prejuízo com as reuniões canceladas) e pelos danos morais, já que não pôde participar dos encontros profissionais importantes para ele. Condenações como essa 
ajudam a evitar que as empresas aéreas lucrem mesmo desrespeitando seus clientes e transferindo para eles prejuízos que, na verdade, deveriam ser assumidos por elas.

\section{q) FALTOU SOCORRO NO HOTEL. DE QUEM É A CULPA?}

Fonte: Viagem e Turismo, outubro de 1999, ano 5, nº 10, edição 48.

Diversos

\section{A queixa.}

“Levei meus dois filhos ao parque aquático da Pousada do Rio Quente, em Caldas Novas, Goiás, mas o que menos consegui foi me divertir. Tudo começou com o escorregão que meu filho mais velho, de 13 anos, levou ao sair da piscina, machucando bastante a boca. Ele usa aparelho dentário e chegou a ficar com três dentes soltos por causa da queda. Desesperada, procurei ajuda de algum funcionário do hotel e descobri que não havia ninguém por ali com a função de zelar pela segurança dos freqüentadores do parque. Na portaria, perguntei sobre o ambulatório e quase caí de costas com o que ouvi: ninguém sabia onde era! Depois de algum tempo, consegui achar o ambulatório, que também foi uma decepção completa. A enfermeira se limitou a dizer que meu filho precisava de um analgésico, mas eu teria de comprá-lo numa farmácia fora do hotel, porque eles não tinham esse medicamento. Quando perguntei pelo médico, ela disse que ele poderia dar uma olhadinha no menino, mas cobraria 40 reais. Irritada, deixei o hotel atrás de socorro decente na cidade. Nem o táxi eles me ajudaram a chamar. Um completo desrespeito aos clientes.” Maria Lúcia Urban, São Paulo, SP.

\section{A defesa.}

Ficamos sensibilizados com os comentários da sra. Maria Lúcia e, em atenção a ela, informamos que um novo ambulatório médico será construído nas dependências do nosso Hotel Park até dezembro próximo. Quanto ao atendimento de nossos funcionários, estamos efetuando um treinamento para que problemas como o relatado não se repitam. Carlos Emílio de Castro Mauad, Diretor de Marketing da Pousada Rio Quente.

\section{A conclusão.}

Todo hotel classificado pela Embratur deve estar equipado para prestar primeiros socorros, segundo o responsável pela Regulamentação de Meios de Hospedagem da 
entidade, Humberto Pires. A cobrança do serviço, porém, é decidida pelo hotel. A Pousada do Rio Quente tem o direito, portanto, de cobrar pela consulta médica. Mas o fato de abrigar um parque aquático aumenta a sua responsabilidade de oferecer um bom atendimento no ambulatório. Isso não está escrito em lei, mas faz parte do bom atendimento que todo cliente espera”

\section{r) A QUEIXA.}

Fonte: Viagem e Turismo, Setembro de 1996, Ano 2, nº 9, edição 11

Férias frustradas

“Comprei, na agência Mundial de Turismo, em Itajaí, Santa Catarina, um pacote da operadora CWB, de Curitiba, para passar uma semana em Porto Seguro. A agência foi competente. Os serviços da operadora CWB, no entanto, quase puseram a pique o passeio. Logo de saída, percebi que a data e o horário da passagem de regresso estavam incorretos. Chegamos a Porto Seguro, notifiquei o erro a um agente da CWB, que não resolveu o problema em tempo hábil. Mas, se fosse apenas isso, teria sido uma maravilha. Ocorre que aborrecimentos não faltaram. Contratei um hotel quatro estrelas, o Beach Hills Hotel. Esse hotel pode ser qualquer coisa, menos um quatro estrelas. Coube-nos, a mim e minha mulher, o quarto 161, cujo guarda-roupa, feito de madeira não de caixaria, não tinha porta.os colchões eram mais duros que a madeira do guarda- roupa. No banheiro, a porta do boxe quase despencava cada vez que era movida. No que se refere à alimentação, a comida piorava à medida que os dias passavam. A carne, quando havia, era refugo. $\mathrm{O}$ curioso é que o agente da CWB, ao ser notificado do fato, confidenciou que a comida estava mesmo uma droga. Quanto ao city tour, ele se referiu a uma fugaz passada pela “cidade histórica”, acompanhada de uma parca explicação do guia pouco articulado. Ficou patente que não recebeu a necessária instrução nem orientação sobre a importância do local onde estávamos. No hotel fomos informados de que havia mais cinco passeios extras. Eu pretendia conhecer Ilhéus. Inscrição e pagamento imediatos. Às $22 \mathrm{~h} 00$ da véspera da partida, fui informado de que o passeio fora cancelado. Motivo: não era “vantajoso” para o Grupo Hills, o mesmo do hotel, levar somente quatro passageiros. Com todos estes percalços, fica a pergunta: isto lá é tratamento quatro estrelas? Onde fica a ética e a responsabilidade moral da CWB e do Grupo Hills? Constantin Sokolski, Camboriú, SC. 
....e a defesa.

A CWB busca a cada dia aperfeiçoar os seus serviços. O Beach Hills recebe por ano uma grande quantidade de turistas. As reclamações são quase zero. Analisamos as queixas do senhor Sokolski, que já tinha entrado em contato conosco, e tomamos providências para que os fatos não voltem a acontecer. Quanto ao passeio para Ilhéus, trata-se de um opcional. Logo, não podemos acompanhar a qualidade desses serviços. É importante que haja clientes como ele, pois assim podemos melhorar nosso trabalho. Arnaldo Lewandowski, Diretor comercial da CWB.”

\section{s) VAZOU ÁGUA NO HOTEL E A EXCURSÃo NAUFRAGOU.}

Fonte: Viagem e Turismo, Setembro de 1999, ano 5, nº 9, edição 47

\section{A queixa}

“Somos uma pequena agencia do interior de Santa Catarina e viajamos com 68 passageiros numa excursão a Curitiba, rumo ao hotel Eduardo VII. Fizemos as reservas com bastante antecedência, pagamos as diárias integramente e, no ônibus, durante a viagem, ligamos confirmando o horário exato de nossa chegada. Apesar de tosos esses cuidados, quando chegamos ao hotel descobrimos que não havia lugar para os nossos clientes porque, segundo o gerente de reserva de plantão, ocorrera um vazamento em alguns quartos meia hora antes e todos os outros estavam ocupados "por pessoas importantes”. Parte de nossos clientes teve de se acomodada a três quadras dali - um transtorno, já que o grupo queria ficar junto. No fim, descobrimos que as reservas desse outro hotel já tinha sido feitas há muito tempo, o que provava a falsidade da história do vazamento. Virginia de Araújo Osório, Haustur Turismo, Jaraguá do Sul, SC.

\section{A defesa.}

Nesse dia houve um problema na parte hidráulica do hotel e, por isso, alguns apartamentos foram interditados. Embora tenhamos nos esforçado para resolver esse contratempo, não foi possível hospedar todo o grupo, daí termos conseguido lugar em outro hotel da mesma categoria que o nosso. E não houve nenhuma reclamação por parte do grupo. Isaac Maia, Subgerente do Hotel Eduardo VII.

\section{A conclusão.}


A lei está do lado de quem fez a reserva. E o hotel, claro, é responsável pela manutenção de suas instalações - incluindo a prevenção contra vazamentos. O bom senso, entretanto, leva a crer que, se o hotel ofereceu uma alternativa de hospedagem, nas mesmas condições de conforto (o que não fica claro na carta da reclamante), o assunto poderia ser considerado resolvido. Ainda assim, conforme a opinião do advogado Sergio Vieira Miranda da Silva, da Associação Carioca de Defesa do Consumidor, "a agência pode até entrar com esse caso na justiça e pleitear uma indenização.”

\section{t) O HOTEL ESTÁ CERTO}

Fonte: Viagem e Turismo, agosto de 2003, ano 9, nº 8, edição 94

Férias frustradas por Gladston Mamede*

Tempo esgotado.

“Afinal, um hóspede pode ficar algumas horas a mais num quanto de hotel, após o término de sua diária?

Eu e meu marido nos hospedamos no Hotel Paulista Center, na capital de São Paulo, durante a Semana Santa. No último dia, como o nosso check-out seria às $12 \mathrm{~h}$. constatamos a recepção e perguntamos se poderíamos deixar as malas no apartamento até às $16 \mathrm{~h}$. A recepcionista nos disse que teria de encerrar a diária ao meio-dia, mas que permitiria que as bagagens ficassem no apartamento até as $13 \mathrm{~h}$. Fechamos, pagamos a conta e fomos dar mais um passeio pela cidade. Quando retornamos, às 14h, nossas malas e pertences já tinham sido retirados do apartamento e estavam em um quartinho, no hall do hotel. Indagamos se poderíamos trocar de roupa em um dos apartamentos e nos foi negado o pedido. Tivemos de abrir as malas no próprio hall, com as pessoas transitando por ali, e fomos trocar de roupa num banheiro extremamente desconfortável, localizado no primeiro andar. Foi uma total descortesia conosco. Realmente não entendo a recusa, pois o hotel estava desocupado e, se a conta já tinha sido paga e a diária encerrada, qual seria o problema de trocarmos de roupa em um dos apartamentos? Lúcia Pinto, Belém, PA.

O caso de Lúcia teve um desdobramento feliz: após enviarmos a reclamação para o Paulista Hotel, este entrou em contato com nossa leitora, oferecendo-lhe uma diária de cortesia para desfazer a má impressão. Foi uma atitude simpática e exemplar - ainda mais se levarmos em conta que não era uma obrigação. A hospedagem em hotel é contratada por 
diária que habitualmente se iniciam e terminam ao meio-dia; porém, nada impede que o hoteleiro fixe um outro horário para início e encerramento da diária, desde que avise devidamente os consumidores. Oferecer o early chek-in, isto é, o ingresso no quarto antes da hora, ou late check-out (a saída mais tarde) é uma cortesia do estabelecimento.

\section{Quem tem razão}

O hotel. O hóspede não tem direito de se utilizar do quarto, mesmo apenas para trocar de roupa ou ir ao banheiro, se estada já terminou. Aliás, ainda que a diária não esteja vencida, o direito de utilização do quanto termina com o check-out. É claro que o hotel pode eventualmente permitir que o consumidor utilize suas instalações tendo vencido a última diária, mas não é seu dever. Sua obrigação é apenas guardar a bagagem. E, ainda assim, por curto período.

\section{O que fazer.}

Você até pode pedir ao hotel que lhe permita usar o quarto depois do horário ou depois do check-out, mas saiba que se trata de uma cortesia, ok? Se precisar estender sua estadia por mais algumas horas, combine com a gerência, de preferência na hora de fazer a reserva ou, no máximo, durante o check- in. Lembre-se de que, uma vez finda a sua estada, você somente poderá utilizar as áreas públicas do hotel (por exemplo, o banheiro do saguão), acordos como o que Viagem intermediou para Lúcia podem acontecer, claro. Mas não são as coisas mais comuns do mundo”.

* Gladston Mamede é bacharel e doutor em direito pela UFMG e autor do Manual de Direito para Administração Hoteleira.

\section{u) PAgOU ANTECIPADO, MAS QUASE FOI DESPEJADO.}

Fonte: Viagem e Turismo, agosto de 2003, ano 6, nº 8, edição 58.

\section{A queixa.}

"Eu e meu marido compramos um pacote da CVC para o Resort Blue Tree Park Cabo Santo Agostinho, pelo qual pagamos antecipadamente. Ao desembarcarmos em Recife, porém, tivemos a desagradável surpresa de ser informados que não poderíamos ficar no hotel, porque estava lotado, num típico caso de orverbooking. Em troca, nos fez 
um proposta que consideramos indecente: uma semana num hotel cinco estrelas do Recife, com refeições e passeios incluídos, mais uma semana no Blue Tree Park, só que em uma outra oportunidade, fora da temporada. Ora, como é possível que os representantes de um hotel aleguem overbooking, quando todos os pagamentos foram feitos com antecedência e tínhamos os vouchers na mão? É importante notar, ainda, que os dois funcionários da CVC presentes à reunião em nenhum momento intercederam em favor dos passageiros, limitando-se a eximir sua empresa de qualquer responsabilidade pelo caso. Diante de nossa indignação, fomos finalmente levados ao resort, mas a essa altura o clima de irritação já estava instalado. Eles deveriam, no mínimo, ter dado melhores explicações. Regina Martins, São Paulo, SP.

\section{A defesa.}

Realmente, propusemos à cliente e seu marido trocar a reserva no Blue Tree Park pela estada num hotel cinco estrelas do Recife, além de garantir uma semana no resort em outra ocasião e o ressarcimento do valor que ela havia pago. Mas, diante da recusa deles, o casal foi acomodado no resort sem maiores contratempos. Heber Garrido, Gerente de marketing do Blue Tree Park.

\section{A conclusão.}

A última coisa que um turista quer ouvir, em plena férias, é que não há mais lugar para ele no hotel que ele reservou e pagou com antecedência. Assim, é fácil entender a bronca da leitora, mesmo em casos como esse, em que a compensação oferecida pelo hotel foi razoável (aliás, bastante razoável). Pelo menos, o resort reparou o erro a tempo, devendo à leitora apenas um pedido formal de desculpas - o que, parece, já foi feito.

\section{v) O INCRÍVEL CASO DOS HÓSPEDES QUE FORAM DESPEJADOS NO NATAL.}

Fonte: Viagem e Turismo, fevereiro de 1999, ano 5, n²2, edição 40

\section{A queixa.}

“Em dezembro de 1997, comprei um pacote para Natal, da Panexpress, pela Interair Agência de Viagens e Turismo, de São Bernardo do Campo, SP. Para começar o avião, que era fretado e devia ter partido às $18 \mathrm{~h} 30$, só decolou no dia seguinte. Depois, o hotel que 
havíamos escolhido, o Village Ponta Negra, não tinha mais vagas e fomos levados ao Enseada Praia Hotel. Três dias depois, ao voltarmos de um passeio, descobrimos que o nosso quarto tinha sido cedido a outros hóspedes e nossas coisas, devidamente embaladas em sacos de lixo, jogadas na recepção do hotel. Não pediram a nossa autorização, nem ao menos nos informaram de nada. Limitaram-se a explicar que não poderíamos mais ficar lá, porque eles precisavam do quarto e ponto. Como isso é possível? Para piorar, meu presente de Natal, um par de óculos de sol, sumiu. Fomos, então, transferidos para outro hotel e passamos a noite de Natal na delegacia de polícia, dando queixa dos óculos. Na volta, a Interair culpou a Panexpress que, por sua vez, queria me reembolsar apenas R\$ 48 . Quando recorri ao Procon e Decon, a oferta subiu para 50\% do valor que paguei. Não aceitei. Afinal, perdi minhas férias e acho justo que eles me dêem uma outra viagem e também no Natal. Entrei, então com outra ação, desta vez judicial, e estou esperando uma decisão. Luiz Carlos Fernandes, São Bernardo do Campo, SP.

\section{A defesa.}

Pagamos as diárias ao hotel Village Ponta negra, que nos eximiu de qualquer culpa. Foi iniciativa deles acomodar os passageiros no Hotel Enseada, já que sua central de reservas havia feito overbooking. Só soubemos disso quando os passageiros já tinham saído. Portanto, nada pudemos fazer”. Walter Folgatti, Panexpress Tours.

\section{A conclusão.}

A reclamação é justa e certamente cabe indenização por parte da Panexpress. Mas vale informar ao leitor (e a outros que estejam em situação semelhante) que a sentença da ação judicial prevalece sempre sobre a decisão na esfera do Procon - e, portanto, só vale a pena recorrer à Justiça Comum depois do veredicto do Procon, mais rápido menos burocrático. A ação judicial é, quase sempre um processo mais lento e custoso. De qualquer forma, em casos como esse os juízes têm arbitrado indenizações no valor de 100 salários mínimos cerca de $\mathrm{R} \$ 13.000,00$. Bem mais, portanto, que os $\mathrm{R} \$ 48,00$ propostos.” 


\section{CÓPIAS EM ANEXO:}

1. Regulamento Geral dos Meios de Hospedagem - Anexo da Deliberação Normativa n. 429 da EMBRATUR

2. Teses Do $5^{\circ}$. Congresso Brasileiro de Direito do Consumidor-Indenização do Dano Moral nos Serviços de Turismo - Marotta Wander. In Revista do Direito do Consumidor, $\mathrm{n}^{\circ}$ 37. Belo Horizonte: Maio, 2000.

3. Artigos publicados

a) Acidentes no Hotel - Responsabilidade. AMAYA, Ingrid Melania Resmusen. Disponível na Internet em: www.nbb.com.br. Acesso em 11 nov. 2003.

a) Direitos de Hóspedes ficam mais claros. CARVALHO, Vininha F. Disponível na Internet em: www.nossaterra.com.br. Acesso em 09 jun. 2003

b) Contrato de Administração Hoteleira. BARBOSA, Ana Beatriz Nunes. Disponível na Internet em: www.nbb.com.br. Acesso em 11 nov. 2003.

c) Dano Moral e Material - Responsabilidade Civil no Código do Consumidor. KADRI, Adnan El. Disponível na Internet em: www.webnewexpress.com.br. Acesso em 03 nov 2003.

d) O Conceito de segurança para Parques Temáticos. BRASILIANO, Antônio Celso Ribeiro. Disponível na Internet em: www.brasiliano.com.br. Acesso em 16 nov 2003.

e) Operadoras de Turismo. CARVALHO, Antonio Carlos Alencar. Disponível na Internet em: www.neofito.com.br. Acesso em 16 nov. 2003.

f) Pacotes Turísticos - Agencias de Turismo respondem pelos serviços do hotel. CARVALHO, Antonio Carlos Alencar. Disponível na Internet em: www.conjur.uol.com.br. Acesso em 16 nov 2003.

g) Quando o Turismo não traz diversão. ATHENIENSE, Luciana Rodrigues. Disponível na Internet em: www.atheniense.com.br. Acesso em 19 nov. 2003.

h) Reparação de danos - Hotel deve indenizar por sumiço de chaves de hospede. ZANONI, José Tadeu Picolo. Disponível na Internet em: www.conjur.uol.com.br. Acesso em 24 nov. 2003.

i) Responsabilidade dos hotéis pelos seus cofres. BARBOSA, Denis Borges. Disponível na Internet em: www.denisbarbosa.addr.com. Acesso em 11 nov. 2003. 
j) Responsabilidade solidária da agência de viagem e operadora. ATHENIENSE, Luciana Rodrigues. Disponível na Internet em: www.direitoeassessoria.com.br. Acesso em 21 nov. 2003.

4. Roteiros Simplificados para o Autor E O Réu no Juizado Especial Cívil.

5. Jurisprudências do STJ. 